\title{
O problema da motivação moral em Kant
}

\author{
Hélio José dos Santos e Souza
}

SOUZA, HJS. O problema da motivação moral em Kant [online]. São Paulo: Editora UNESP; São Paulo: Cultura Acadêmica, 2009. 141 p. ISBN 978-85-7983-016-7. Available from SciELO Books <http://books.scielo.org>.

\section{(1) (1) @()}

All the contents of this work, except where otherwise noted, is licensed under a Creative Commons Attribution-Non Commercial-ShareAlike 3.0 Unported.

Todo o conteúdo deste trabalho, exceto quando houver ressalva, é publicado sob a licença Creative Commons Atribuição Uso Não Comercial - Partilha nos Mesmos Termos 3.0 Não adaptada.

Todo el contenido de esta obra, excepto donde se indique lo contrario, está bajo licencia de la licencia Creative Commons Reconocimento-NoComercial-CompartirIgual 3.0 Unported. 
- PROBLEMA

DA MOTIVAÇÃO

MORAL EM KANT

HÉLIO JOSÉ DOS SANTOS SOUZA 


\section{O PROBLEMA DA MOTIVAÇÃO MORAL EM KANT}





\section{HÉLIO JOSÉ DOS SANTOS SOUZA}

\section{O PROBLEMA DA MOTIVAÇÃO MORAL EM KANT}

CULTURA $\frac{\text { ACADÊMICA }}{\mathcal{E} \text { diton }}$ 


\section{(C) 2009 Editora UNESP}

\section{Cultura Acadêmica}

Praça da Sé, 108

01001-900 - São Paulo - SP

Tel.: (0xx11) 3242-7171

Fax: (0xx11) 3242-7172

www.editoraunesp.com.br

feu@editora.unesp.br

CIP - Brasil. Catalogação na fonte

Sindicato Nacional dos Editores de Livros, RJ

\section{S716p}

Souza, Hélio José dos Santos

O problema da motivação moral em Kant / Hélio José dos Santos e Souza. - São Paulo : Cultura Acadêmica, 2009.

Inclui bibliografia

ISBN 978-85-7983-016-7

1. Kant, Immanuel, 1724-1804. 2. Ética. 3. Razão. I. Título.

09-6209.

CDD: 170

CDU: 17

Este livro é publicado pelo Programa de Publicações Digitais da Pró-Reitoria de Pós-Graduação da Universidade Estadual Paulista "Júlio de Mesquita Filho" (UNESP)

Editora afiliada:

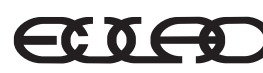

Asociación de Editoriales Universitarias de América Latina y el Caribe

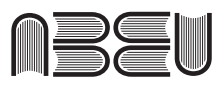
Associação Brasileira de
Editoras Universitárias 
Agradeço a minha família, que sempre me incentivou.

De forma especial, agradeço à Adriana, pelo apoio nos momentos dificeis.

Aos amigos, sobretudo ao Rogério, pelo auxílio.

Ao professor Ricardo Monteagudo, meu orientador. À Capes, por financiar parte desta pesquisa. 



\section{SUMÁRIO}

Prefácio 9

Introdução 13

1 A vontade diante de uma encruzilhada 17

2 Os princípios da razão prática 43

3 Dos motivos determinantes da vontade 81

4 Interesse da razão e liberdade 109

Considerações finais 131

Referências bibliográficas 139

Bibliografia suplementar 140 



\section{Prefácio}

Por que os homens são livres? No que consiste a liberdade humana? Como é possível a ação moral? Como um corpo submetido a leis naturais pode ser livre? Para responder perguntas simples como estas e outras não tão simples é que Hélio José dos Santos Souza se debruça sobre a obra de Kant, especialmente a Fundamentação da metafísica dos costumes. Como bem observa o autor, "pretende-se analisar os conceitos de boa vontade, dever, lei, imperativo, respeito, interesse e liberdade". Qualquer criança precisa ter uma breve noção destas palavras importantes para se constituir como homem de bem, como cidadão consciente. Ao projetá-los no sistema kantiano, encontramos uma formulação mais elevada, resultado de séculos de reflexão filosófica, que nos ajudam a pensar a nossa realidade.

O problema é complexo: trata-se de saber se a moralidade e a ética são expressões de um princípio racional incondicionado igualmente presente nas leis imutáveis da natureza. Nesse caso, haveria continuidade entre a natureza e a moralidade, o direito natural exprimiria deveres que se impõem à vontade de cada um, a liberdade seria uma ilusão da consciência que não reconhece todas as cau- 
sas naturais que a condicionam. Esse é o resultado da filosofia moderna de Espinosa e Hobbes, que Kant pretende superar. A solução é uma inversão do problema: a liberdade e o conhecimento da natureza são condicionados no homem pela razão. Nesse caso, como a liberdade pode ser deduzida a partir da sensibilidade? Parece que a cada reformulação novos problemas aparecem e os conceitos multiplicam-se.

O que leva o homem a agir moralmente? Se identificamos o dever ser e o dever, naturalizamos o transcendental e a resposta kantiana repetiria a filosofia moderna de cujas aporias a crítica pretende escapar. Se por outro lado recorremos à divindade, voltamos às dificuldades que foram respondidas pela filosofia moderna. Vejamos um exemplo: Édipo descobre que uma maldição o conduzirá ao parricídio, para evitar esta desgraça foge de sua casa e de sua cidade. Ao fugir, encontra em uma encruzilhada um homem que o desrespeita e o desafia, então mata este homem sem saber que este é seu verdadeiro pai. O conflito moral gerado pela maldição conduz uma iniciativa que desencadeia a própria maldição, pois Édipo não sabia que era filho adotivo. Ora, a lei que impede o parricídio foi ou não foi respeitada? A motivação moral da fuga foi uma decisão individual de Édipo ou uma imposição divina? Como caracterizar a boa vontade neste caso? Havia um imperativo moral que foi seguido, mas o que deveria ter sido evitado foi, ao contrário, provocado pela boa vontade de agir moralmente. Por outro lado, a reação intempestiva de Édipo ao ser desafiado é passional e não segue as prescrições da reta razão. A natureza humana é cindida e tem duas fontes de determinação; retornamos à encruzilhada de Édipo: calar-se ou resistir ao desafio moral do parricídio? Calar-se ou resistir à ameaça de alguém? O princípio formal racional não basta para lidar com o problema: daí a razão prática pura, também analisada nesta pesquisa. 
O que é mais interessante neste livro é que uma questão técnica kantiana é transformada em uma questão apaixonante. Não apenas a descrição da coisa em si moral oriunda da racionalidade e sua manifestação por meio de imperativos categóricos que se impõem pela reflexão, mas o que motiva o homem a agir moralmente. $\mathrm{O}$ medo da punição, a universalidade da razão, o desejo de felicidade, o equilíbrio psicológico, os benefícios materiais etc. não são em si suficientes para compreender a riqueza e diversidade da experiência humana. A questão é como é possível nos tornarmos homens melhores apesar de sermos homens. Hélio José apresenta ainda a discussão destes problemas por alguns dos grandes intérpretes da obra de Kant, o que enriquece filosoficamente a análise e as alternativas pertinentes.

Este é um daqueles trabalhos aparentemente acadêmicos que podem estabelecer a vocação filosófica de seus leitores: a reflexão sobre o que está em jogo é por si só um prazeroso exercício do filosofar. 



\section{INTRODUÇÃO}

A Fundamentação da metafísica dos costumes tem por finalidade encontrar o princípio supremo da moralidade que reside, segundo Kant, já no bom senso natural. A investigação procede, ao menos nas duas primeiras seções da Fundamentação, de modo analítico, e aponta a razão prática pura como o fundamento de uma boa vontade. Segundo Kant, somente a razão é suficientemente capaz de fornecer, totalmente a priori, o princípio incondicionado da moralidade válido para a vontade de todo ente racional.

Surge, porém, um problema: por queé que devemos nos submeter à lei moral? O que é capaz de motivar o homem a agir conforme o imperativo categórico e, portanto, moralmente? O presente trabalho pretende examinar, a partir dos apontamentos realizados por Kant, como pode o ente racional agir motivado pela lei, motivação esta necessária para que a moral se estabeleça.

Para tanto, pretende-se analisar os conceitos de boa vontade, dever, lei, imperativo, respeito, interesse e liberdade. Todos estes conceitos constituem a espinha dorsal da argumentação kantiana no texto da Fundamentação. O grande problema é que Kant nem sempre esclarece com 
preciso cuidado o significado destes conceitos e a ligação sistemática em que ele os utiliza. Pretendemos tornar alguns pontos menos obscuros, pois sem compreender estes conceitos, consequentemente, a filosofia moral de Kant também permanecerá incompreendida.

Optamos pela divisão do trabalho em quatro capítulos. O primeiro capítulo analisa o conceito de boa vontade e pretende mostrar que sua formação depende de que a razão prática pura determine a vontade de modo totalmente a priori. Mas o homem, por sua vez, encontra uma enorme dificuldade em agir conforme as prescrições da razão em função da ambivalência de sua própria natureza, que é constituída também de sensibilidade. Por isso, na consciência de si, o homem se vê como um ente cindido entre duas partes heterogêneas, uma natureza sensível e outra racional, deixando, desse modo, a vontade diante de duas fontes distintas de determinação e, por assim dizer, em uma encruzilhada.

No segundo capítulo, traçaremos a distinção entre o princípio formal racional e o princípio material sensível para verificar se a razão prática pura é suficientemente capaz de determinar objetivamente a vontade de todo ente racional.

No terceiro, nossa investigação trata de perguntar pelo fundamento da escolha, ou seja, pelo motivo determinante da vontade, no sentido de procurar desvendar o que pode motivar o homem a agir moralmente em face das inclinações sensíveis. Este capítulo pretende, portanto, primeiramente explicar por que o homem carece de um motivo para agir moralmente, mesmo tendo o conhecimento de que somente uma vontade boa determinada pelo imperativo categórico é que pode promover boas ações, e apontar, em seguida, os possíveis elementos motivacionais do homem na escolha do princípio puro como fonte de determinação da vontade. 
O quarto e último capítulo pretende mostrar que a lei moral interessa ao homem porque ela é um produto de sua razão, isto é, efeito de sua liberdade enquanto um ente do mundo inteligível. 



\section{1 \\ A VONTADE DIANTE DE UMA ENCRUZILHADA}

$\mathrm{Na}$ Fundamentação, Kant assume a proposição que diz ser a boa vontade o único bem incondicionado como regra de ajuizamento moral, justificando que se trata de um dado proveniente da consciência moral que o homem comum tem do dever e, por isso, possui validade objetiva. O presente capítulo pretende mostrar, porém, que a formação de uma boa vontade depende de que a razão prática pura determine a vontade de modo totalmente a priori, visto que sem este pressuposto, a noção de boa vontade está fadada a ser apenas uma quimera. Mas o homem, por sua vez, encontra uma enorme dificuldade em agir conforme as prescrições da razão em função da ambivalência de sua própria natureza, que é constituída também de sensibilidade. Por isso, na consciência de si o homem se vê como um ente cindido entre duas partes heterogêneas, uma natureza sensível e outra racional, deixando, desse modo, a vontade diante de duas fontes distintas de determinação e, por assim dizer, em uma encruzilhada. Por conta da ambivalência de sua natureza, o homem terá, portanto, de decidir entre dois princípios distintos, ou seja, caberá a ele escolher se determina sua vontade exclusivamente conforme o princípio 
racional ou se se deixa seduzir por completo pelas solicitações do desejo sensível e determina a vontade segundo o princípio egoísta.

\section{A boa vontade}

A investigação empreendida por Kant na Fundamentação da metafísica dos costumes em busca do princípio supremo da moralidade toma como ponto de partida a seguinte proposição: "Neste mundo, e até também fora dele, nada é possível pensar que possa ser considerado como bom sem limitação a não ser uma só coisa: uma boa vontade" (Kant, 2005, p.21, grifo do autor).

Disso, porém, que a boa vontade seja o único bem que possamos considerar como irrestrito, não se pode concluir que não haja outros bens. O próprio Kant elenca um número de coisas que, sem dúvida, podem ser tomadas por boas e que são até mesmo desejáveis. Por exemplo: os dons naturais, divididos entre os talentos do espírito como discernimento, capacidade de julgar; as qualidades do temperamento, como coragem e decisão; além dos dons da fortuna, como poder, riqueza e felicidade. Todas essas coisas são bens estimáveis, todavia, Kant (2005, p.25-6) adverte: "Esta vontade não será na verdade o único bem nem o bem total, mas terá de ser contudo o bem supremo e a condição de tudo o mais, mesmo de toda a aspiração de felicidade".

Vale notar que Kant poderia soar paradoxal por ora admitir, como na proposição, que a boa vontade constitua o único bem sem limitação, e depois afirmar em outra passagem que ela não seja o bem total. Que a boa vontade não constitua o único bem fica claro a partir dos exemplos citados acima de coisas que podem ser consideradas como boas, ainda que não tenha ficado evidente de que modo estas coisas possam representar um bem. 
A diferença entre a boa vontade e as outras coisas reside no fato de que a primeira constitui um bem irrestrito e, portanto, incondicionado, ao passo que as demais são estritamente dependentes do princípio de uma boa vontade como condição indispensável da bondade atribuída a elas. Os dons naturais podem ser bons desde que a vontade que haja de fazer uso deles seja boa, pois do contrário, se, por exemplo, deles faz uso uma má vontade, consequentemente, eles podem se tornar maus.

Portanto, trata-se de bens cujo valor atribuído é relativo, isto é, eles obtêm valor moral quando faz uso deles uma boa vontade, ao passo que o valor de uma boa vontade é incondicionado. Desse modo, fica estabelecido que somente a vontade pode ser considerada boa ou má, e nesse sentido, todos os efeitos decorridos dela, como por exemplo as ações, recebem juízo de valor relativamente ao princípio determinante da vontade, pois apenas os princípios podem ser considerados bons ou maus. Notar-se-á queé neste ponto que a ética formal kantiana começa a distinguir-se das éticas anteriores consideradas materiais, ou éticas de conteúdo.

Contudo, cabe a pergunta: o que torna uma boa vontade um bem incondicionado? No primeiro momento, Kant deixa entrever que uma vontade boa é aquela que, independentemente das consequências de seus efeitos, ou seja, considerada em si mesma, permanece envolvida com a bondade, o que destina à vontade o caráter de um bem incondicionado.

A boa vontade não é boa por aquilo que promove ou realiza, pela aptidão para alcançar qualquer finalidade proposta, mas tão-somente pelo querer, isto é, em si mesma, e, considerada em si mesma, deve ser avaliada em grau muito mais alto do que tudo o que por seu intermédio possa ser alcançado em proveito de qualquer inclinação, ou mesmo, se se quiser, da soma de todas as inclinações. (Kant, 2005, p.23) 
Kant, desse modo, assume o conceito de boa vontade como regra para o julgamento moral que, segundo ele, provém da ideia que o homem comum tem do dever e das leis morais, e que reside já no bom senso natural, carecendo, pois, mais de um exame para determinar as condições de sua possibilidade e, deste modo, apontar o princípio no qual deva repousar este conceito, do que propriamente ser ensinado ao homem comum. ${ }^{1}$ Considerada desse modo, a boa vontade constitui-se como o princípio formal de toda a moralidade.

Se, como afirma Kant, o conceito de boa vontade reside verdadeiramente no bom senso natural, então, todo homem, desde o mais simples ao mais culto, carregaria consigo, portanto, a regra para julgar o valor de suas ações. E mediante esta regra, a razão humana no campo moral poderia ser levada a um alto grau de justeza e desenvolvimento, pois mesmo o homem comum encontraria nela a regra, oriunda de sua própria consciência, para avaliar se sua ação pode ser considerada moralmente boa. Com efeito, se a existência do absolutamente bom está restringida a uma única coisa, a saber, a uma boa vontade, todas as coisas restantes, para que possam ser consideradas boas, dependeriam, como condição indispensável, de que tenham sido produzidas por uma boa vontade. No caso do agir humano, por exemplo, a realização de uma boa ação estaria indissoluvelmente dependente de uma boa vontade como condição necessária de sua realização, ou seja, se a vontade não for boa, dela também seria impossível decorrer uma boa ação.

Isto é um dado importante porque significa que, para Kant, não é preciso ser culto para se ter uma consciência moral formada para se poder agir moralmente. O homem menos culto é capaz de julgar moralmente bem, mesmo que não seja capaz de justificar teoricamente os princípios que

1 Cf. Kant, 2005, p.26. 
o levam a afirmar a bondade ou a maldade de uma determinada ação humana. Neste sentido, o homem comum não carece de muita perspicácia para saber o que tem de fazer para agir moralmente bem, pois até mesmo a razão do homem comum é capaz de obter o conhecimento moral necessário para bem julgar suas ações. Como afirma Kant (2005, p.35-6):

Basta, sem que com isto lhe ensinemos nada de novo, que chamemos a sua atenção, como fez Sócrates, para o seu próprio princípio, e que não é preciso nem ciência nem filosofia para que ela saiba o que há a fazer para se ser honrado e bom, mais ainda, para se ser sages e virtuoso.

Para, no entanto, mostrar a autenticidade e o valor absoluto que comporta o conceito de boa vontade, faz-se necessário estabelecer o princípio no qual ele está fundado, caso contrário, teria este conceito de disputar com outros preceitos práticos ao posto de regra moral de conduta. Kant a fim de determinar este princípio empreende, ao menos nas duas primeiras seções da Fundamentação, uma investigação analítica, na qual ele analisa os possíveis fundamentos sobre os quais possa repousar a noção de boa vontade. Como afirma Tugendhat (1996, p.140):

Pode-se considerar a primeira seção da Fundamentação como uma genial tentativa, talvez não de deduzir, mas de tornar convincente o imperativo categórico a partir de um aspecto central da compreensão comum. Que uma dedução nesta base seja impossível, resulta já do fato de ser o aspecto da consciência moral comum, do qual partiu Kant, um elemento de uma moral em geral e já por isto não poder ter sido derivado dele o programa moral específico do imperativo categórico.

Após o exame analítico da questão, a terceira e derradeira seção procede de modo sintético, no qual Kant procura- 
rá mostrar a partir do princípio fundante de uma boa vontade sua aplicabilidade no julgamento moral dos costumes humanos.

Mas, por conta de Kant admitir o conceito de boa vontade como um dado extraído da moral do senso comum, sem oferecer uma explicação prévia sobre o modo pelo qual este conceito se constitui como regra de conduta, o ponto de partida da investigação kantiana acaba se tornando vulnerável a críticas. Poder-se-ia perguntar sobre sua plausibilidade junto ao homem de entendimento vulgar. Seria a noção de boa vontade reconhecida tão facilmente pela consciência humana como sendo ela o único bem sem limitação? A afirmação da qual parte Kant faz realmente sentido, ou seja, o homem comum pode por si mesmo compreender, sem uma explicação ulterior, que a boa vontade se constitui como regra válida para o ajuizamento moral e, desse modo, a partir dela decidir sobre o que fazer ou deixar de fazer?

Paton argumenta que palavras como bom sem limitação ou como boa vontade merecem ser explicadas para que se compreenda a proposição admitida por Kant e, assim, soe plausível aos ouvidos do homem comum. Sem esta explicação, Kant estaria tomando como ponto de partida um princípio que, por conta de sua intrínseca complexidade, se constituiria insatisfatório como regra moral ao entendimento vulgar. Por isso Paton (1971, p.34, tradução nossa) diz:

Isso deve ser admitido, embora declare ser um juízo moral comum, não é o tipo de afirmação que um homem comum normalmente aceita [...]. Contudo, a questão levantada é a da moral interior comum; e sem maiores análises, a afirmação é muito vaga para ser considerada um princípio moral satisfatório. ${ }^{2}$

2 "This, it must be confessed, although it profess to be an ordinary moral judgement, is not the kind of utterance in which the ordinary 
$\mathrm{Na}$ Fundamentação, Kant deixa de explicitar o modo pelo qual ele extraiu o conceito de boa vontade, ou seja, de que modo este conceito surge como um dado da moral do senso comum e, por isso, a questão acerca da origem desta afirmação da qual a investigação kantiana parte fica sem resposta.

Aparentemente, a noção de boa vontade como regra moral seria um dado constatado por Kant a partir de observações nas quais se percebe a concordância do entendimento do homem comum com esta ideia no julgamento sobre o valor das ações humanas. Com efeito, se a noção de boa vontade como regra prática não parece tão certa e evidente ao homem comum como parece ser para Kant, vale notar que, quando julgamos uma ação de modo moral, é a vontade determinadora da ação o que nós estamos julgando em última instância. Ao contrário do que ocorre, por exemplo, quando julgamos uma ação sob a perspectiva do Direito.

Comumente ouvimos expressões do gênero: o sujeito agiu de má vontade ou faltou boa vontade do sujeito ao realizar determinada ação. Mesmo que o efeito da ação tenha atingido o objetivo previamente pretendido, fica claro que se o motivo determinante da vontade não tiver sido simplesmente o bem incondicionado, isto é, se a ação não tiver sido decorrida de uma boa vontade, ela estará desprovida de conteúdo moral, pois é a intenção da ação que está sendo julgada nestes casos. Como afirma Ricardo Terra (2004, p.15), no campo do Direito, as ações são julgadas de outro modo: "No plano jurídico não se permanece no âmbito da intenção, e apenas a exterioridade das ações é considerada".

good man habitually indulges [...]. Nevertheless the question raised is one for ordinary moral insight; and without further analysis the statement is too vague to be regarded as a satisfactory moral principle." 
Se Kant, por um lado, deixa de explicitar o modo pelo qual a noção de boa vontade se constitui como regra da moral do senso comum, por outro, podemos encontrar em determinada passagem da Fundamentação a explicação do que se deve entender por bom sem limitação sob a perspectiva da filosofia prática:

Praticamente bom é porém aquilo que determina a vontade por meio de representações da razão, por conseguinte não por causas subjectivas, mas objectivamente, quer dizer por princípios que são válidos para todo o ser racional como tal. Distingue-se do agradável, pois que este só influi na vontade por meio da sensação em virtude de causas puramente subjectivas que valem apenas para a sensibilidade deste ou daquele, e não como princípio da razão que é válido para todos. (Kant, 2005, p.48, grifo do autor).

Com esta passagem, Kant parece clarificar um dos pontos que para Paton estava obscuro na proposição, a saber, o sentido do termo bom sem limitação. Já para desobscurecer o sentido do conceito de boa vontade, primeiramente precisamos esclarecer certa ambiguidade que envolve o termo vontade.

Vontade é o termo mais comum empregado por Kant para referir-se à faculdade de apetição ou faculdade de desejar (Begehrungsvermögens), embora se possa facilmente encontrar em seus escritos, sob o nome de arbítrio, referências a esta mesma faculdade do ânimo. Ora o emprego do termo vontade, ora o do termo arbítrio, deixa pairar a dúvida se Kant realmente não estaria tratando de dois assuntos diferentes. No entanto, segundo Allison (1995, p.129, tradução nossa), as utilizações de dois termos distintos são para caracterizar as funções de uma única faculdade:

Kant usa os termos Wille e Willkür para caracterizar respectivamente as funções legislativas e executivas de uma 
unificada faculdade de desejar, à qual ele, do mesmo modo, se refere como Wille. Portanto, Wille tem um significado amplo, no qual conota a faculdade de desejar ou a vontade como um todo, e um sentido restrito, em que há a conotação de uma função dessa faculdade. ${ }^{3}$

Kant, portanto, emprega o termo Vontade, em sentido geral, como sinônimo da faculdade de desejar e, em sentido restritivo, como a função legislativa desta mesma faculdade do ânimo. Quando utilizado, o termo arbítrio concerne à função executiva da faculdade de desejar. Em resumo, temos o seguinte quadro: a faculdade de desejar é comumente denominada Vontade, e os termos vontade e arbítrio nomeiam respectivamente duas funções distintas desta faculdade; a primeira promulga o princípio moral de conduta, ao passo que a segunda opta por executar ou não a ação conforme este princípio.

$\mathrm{Na}$ Fundamentação, Kant concebe a vontade "como a faculdade de se determinar a si mesmo a agir em conformidade com a representação de certas leis. E uma tal faculdade só se pode encontrar em seres racionais" (2005, p.67). Como para representar leis, a razão é necessária, a vontade nada mais é senão do que razão prática. No entanto, como salienta Tugendhat (1996, p.141), Kant utiliza de modo ambíguo o termo vontade ao longo do texto, ora se referindo a ele como a vontade já determinada pela razão prática pura, ora como a capacidade de escolha humana (arbítrio), que pode tanto optar pelos princípios da razão, quanto pe-

3 "Kant uses the terms Wille and Willkür to characterize respectively the legislative and executive functions of a unified faculty of volition, which he likewise refers to as Wille. Accordingly, Wille has both a broad sense in which it connotes the faculty of volition or will as a whole and a narrow sense in which it connotes one function of that faculty". 
las inclinações da sensibilidade como motivo determinante da ação.

Efetivamente, ele emprega na Fundamentação o termo 'vontade' com uma ambigüidade que ele resolveu mais tarde na Metafísica dos costumes, na medida em que reserva o termo 'vontade' para esta idéia da razão prática, e isso quer dizer para a vontade já determinada pela razão, e emprega o termo 'arbítrio' no sentido comum do querer, que pode tanto ser racional quanto não.

Valério Rohden, assim como Tugendhat, adverte para o fato de que a distinção entre vontade e arbítrio se deu tardiamente no texto da Metafísica dos costumes, e que tanto na Fundamentação quanto na Crítica da razão prática, Kant não realizou uma distinção clara entre estes termos e sua relação com a razão, que também foi expressa de forma ambígua, ora como razão empírica, ora como razão pura. Conforme Valério Rohden (1981, p.136):

Nestes escritos, Kant distingue meramente entre 'vontade em geral' e 'nossa vontade'; entre 'vontade perfeita' e 'imperfeita'; entre 'vontade afetada sensivelmente' e 'vontade por si mesma prática'. A todas essas distinções correspondem também dois sentidos de razão: 'razão empírica' e 'razão pura'. Noutras passagens, Kant simplesmente toma vontade e arbítrio como sinônimos: ora fala de 'condições subjetivas do arbítrio', ora de 'condições objetivas do arbítrio' (isto é da vontade).

A explicação sobre o sentido empregado por Kant ao conceito de boa vontade decorre, portanto, daquilo que se deve entender por bom em sentido prático, e do modo como ele utiliza o termo vontade. Sendo assim, podemos dizer que boa é a vontade determinada de modo incondicionado, isto é, por princípios da razão pura prática, válidos para 
todo o ente racional. A boa vontade é boa sem limitação, porque está fundada no princípio da razão que, por sua vez, é incondicionado e contém somente a forma do querer abstraído de toda a matéria do objeto. Como afirma Paton (1971, p.34, tradução nossa): "Sua bondade não está condicionada por sua relação a um contexto, a um fim ou a um desejo", por isso, "Nós poderíamos, talvez não impropriamente, descrevê-la como uma "vontade moral".. ${ }^{4}$

Notar-se-á, porém, que a boa vontade depende de que a razão pura possa ser prática, isto é, que ela possa ser suficientemente capaz de fornecer o princípio universal e necessário de conduta. Sem este pressuposto fundamental, a ideia de uma boa vontade como bem incondicionado está fadada a ser uma quimera sem a possibilidade de um uso in concreto. Tomado por esta preocupação, Kant estabelecerá a tentativa de provar a existência de uma razão prática pura como o principal objetivo da Crítica da razão prática. Assim, diz ele no prefácio da Crítica: "Ela deve meramente demonstrar que há uma razão prática pura e, em vista disso, critica toda a sua faculdade prática. Se ela o consegue, não precisa criticar a própria faculdade prática para ver se a razão não se excede, com uma tal faculdade pura, numa vã presunção” (Kant, 2003, p.3, grifo do autor).

Para Kant, no entanto, o homem é capaz de conceber a ideia de uma razão prática pura, mas as inclinações se apresentam como forte empecilho no desenvolvimento desta ideia. Neste sentido, afirma Kant: "O homem, com efeito, afectado por tantas inclinações, é na verdade capaz de conceber a idéia de uma razão pura prática, mas não é tão facilmente dotado da força necessária para a tornar eficaz in concreto no seu comportamento" (2005, p.16).

4 "Its goodness is not conditioned by its relation to a context or to an end or to a desire", por isso, "We might, perhaps not improperly, describe it as 'moral will'”. 
Por conta de o homem possuir, além da razão, a sensibilidade, o arbítrio fica diante de duas fontes possíveis de determinação da vontade, pois o arbítrio humano, ao contrário do que ocorre com o arbítrio dos demais animais que estão fadados a agirem necessariamente mediante impulsos da sensibilidade, é livre para escolher entre uma determinação fundada na razão prática pura ou fundada simplesmente em inclinações.

Um arbítrio é puramente animal (arbitrium brutum) quando não pode ser determinado senão mediante impulsos sensíveis, ou seja, patologicamente. Um arbítrio, porém, que pode ser determinado independente de impulsos sensíveis, e portanto por motivações que só podem ser representadas pela razão, chama-se livre-arbitrio (arbitrium liberum). (Kant, 1980, p.391-2, B 830, grifo do autor)

O arbítrio, portanto, exerce a função de escolha do motivo determinante da vontade, que pode ser determinada tanto por impulsos sensíveis admitidos por meio de inclinações e desejos, quanto por princípios universais e necessários oriundos de representações da razão prática pura. Na primeira forma de determinação o motivo é empírico, ao passo que, da segunda o motivo é racional, e a vontade somente será boa e a ação dela decorrida somente terá conteúdo moral, quando a vontade for determinada por esta última forma, isto é, por um motivo racional.

Portanto, a dificuldade que o homem encontra de aplicar em seu comportamento a ideia de uma razão pura prática, que fornece o princípio de uma boa vontade, parece residir na ambivalência da própria natureza humana, que se constitui de razão e sensibilidade. Por isso, o próximo passo desta investigação propõe um exame acerca da relação entre razão e sensibilidade para verificar a influência de ambas na determinação da vontade. 


\section{A relação entre razão e sensibilidade na determinação da vontade}

Na Fundamentação, encontramos uma explicação teleológica ${ }^{5}$ da constituição do ser humano. Segundo Kant, se aceitarmos que a Natureza agiu com acerto no arranjo das coisas do mundo, no tocante a um ser organizado, cujo fim é a vida, temos de tomar como princípio que nele não se encontra nenhum órgão que não seja apropriado para a consecução deste fim. Notar-se-á que, diferentemente do que ocorre com os outros animais, no homem, além dos sentidos, encontramos nele a razão. Segue-se daqui o aspecto central da concepção kantiana de natureza humana: o homem, dotado de sensibilidade e razão, constitui-se essencialmente como um ser ambivalente, estando sua natureza, desse modo, cindida por uma parte sensível e outra racional. ${ }^{6}$

Dessa oposição entre razão e sensibilidade, Kant (1992, p.32, grifo do autor) afirma que do homem emergem três classes de disposições originárias: "1) a disposição para animalidade do homem como um ser vivo; 2) sua disposição para a humanidade enquanto ser vivo e racional, 3) a disposição para sua personalidade, como ser racional e, simultaneamente, susceptível de imputação".

A disposição para a animalidade consiste no homem o ato de instituir o amor de si simplesmente mecânico, para

5 Cf. Kant, 2005, p.24.

6 Sidney Axinn acredita que Kant seja aquele que tenha se aproximado de uma definição mais exata da natureza humana por conta de a filosofia kantiana ter observado a ambivalência entre razão e sensibilidade. Axinn ainda adverte para o fato dessa ambivalência estar envolvida em tudo aquilo que diz respeito ao sujeito: "Kant nos dá uma concepção mais apurada (e mais digna) da natureza humana; nós somos ambivalentes em relação a tudo e a todos, inclusive à razão e ao ideal da razão" (Axinn, 1981, p.173, tradução nossa). 
o qual não se exige a razão, como fonte de determinação da vontade. Toda ação originada por esta disposição seria calculada pelo homem em vista de três objetivos: o primeiro visando à conservação de si próprio, o segundo em ordem à propagação da espécie por meio do impulso sexual e, por fim, em vista da instituição de uma comunidade por meio do impulso à sociedade. Dessas disposições, porém, podem emergir vícios aos quais Kant denomina de bestiais, que estão classificados em vícios da gula, da luxúria e da selvagem ausência de lei para com outros homens. Esta disposição determina a vontade de modo patológico, com vistas ao bem-estar e à felicidade própria do sujeito.

Tanto o impulso à sociedade quanto o vício de viver sob a ausência de leis foram temas abordados na Quarta Proposição do texto Idéia de uma história universal de um ponto de vista cosmopolita. Nele, Kant (1986, p.13, grifo do autor) atenta para o antagonismo das disposições naturais, que está caracterizada no âmbito social como a insociável sociabilidade dos homens.

Eu entendo aqui por antagonismo a insociável sociabilidade dos homens, ou seja, a tendência dos mesmos a entrar em sociedade que está ligada a uma oposição geral que ameaça constantemente dissolver essa sociedade. Esta disposição é evidente na natureza humana. O homem tem uma inclinação para associar-se porque se sente mais como homem num tal estado, pelo desenvolvimento de suas disposições naturais. Mas ele também tem uma forte tendência a separar-se (isolar-se), porque encontra em si ao mesmo tempo uma qualidade insociável que o leva a querer conduzir tudo simplesmente em seu proveito, esperando oposição de todos os lados, do mesmo modo que sabe que está inclinado a, de sua parte, fazer oposição aos outros.

A disposição para a humanidade refere-se ao amor de si posto como fundamento da vontade, cujo efeito da ação 
visa obter para o homem um valor maior na opinião dos outros. Trata-se de um desejo injusto do homem de adquirir para si uma certa superioridade sobre os demais. Dessa espécie de disposição resulta os vícios da cultura também denominados vícios diabólicos, que se refletem, por exemplo, na inveja, na ingratidão e na alegria malvada. Contudo, a vontade ao ser determinada pela disposição para a humanidade, tende a utilizar a razão como meio para se atingir um fim determinado: a autoestima. Neste ponto, tanto a disposição para a animalidade quanto a disposição para a humanidade têm em comum uma característica: elas determinam a vontade com vistas a satisfazer uma inclinação.

Por fim, encontramos no homem a disposição para a personalidade que nada mais é senão "a susceptibilidade da reverência pela lei moral como de um móbil, por si mesmo suficiente do arbitrio" (Kant, 1992, p.33, grifo do autor). Esta disposição ao determinar a vontade coloca como seu fundamento a mera reverência pela lei, cujo fim a ser atingido não é outro senão a própria moralidade, por isso ela pode ser denominada a verdadeira disposição moral do homem.

$\mathrm{Na}$ Crítica da faculdade do juízo, no entanto, Kant faz referência ao caráter contraditório das disposições naturais. Essa contradição de disposições intrínseca ao homem o impede de atingir a felicidade. Na verdade, a felicidade é a ideia de um estado de pleno gozo ao qual o homem quer se adequar tornando esta ideia objetiva sob condições empíricas. Mas, isto se torna impossível porque as contradições nele existentes dificultam o alcance de um estado de plena satisfação, caracterizando assim a ideia de felicidade como um conceito muito vacilante.

Mas mais ainda, o caráter contraditório das disposições naturais nele [no homem] condu-lo ainda a uma tal miséria, isto é, a tormentos que ele mesmo inventa e a outros produ- 
zidos pela sua própria espécie, mediante a opressão do domínio, a barbárie da guerra etc. e ele mesmo, enquanto pode, trabalha na destruição da sua própria espécie, de tal modo que, mesmo com a mais benfazeja natureza fora de nós, não seria atingido o fim daquela, num sistema seu na terra, no caso de tal fim ser colocado como felicidade da nossa espécie. (Kant, 1995, p.271, grifo do autor).

Entretanto, todos os tormentos produzidos pela espécie humana, seja mediante a opressão do domínio, seja pela barbárie da guerra, entre outros, são necessários para o desenvolvimento das disposições naturais intrínsecas ao homem, porque se por um lado todos estes tormentos se originam na contradição dessas disposições, por outro se estes tormentos não surgissem, seria um sinal de que não houve um desenvolvimento dessas mesmas disposições.

Esta oposição é o que leva a espécie humana a superar sua tendência à preguiça, pois, sem esta tensão entre os homens engendrada pela cobiça ou ânsia de dominação, "todas as excelentes disposições naturais da humanidade permaneceriam sem desenvolvimento num sono eterno" (Kant, 1986, p.14). Ficaria, desse modo, prejudicada a ideia de progresso por meio da Aufklärung, que significa, a grosso modo, "a fundação de um modo de pensar que pode transformar, com o tempo, as toscas disposições naturais para o discernimento moral em princípios práticos determinados e assim finalmente transformar um acordo extorquido patologicamente para a sociedade em um todo moral" (idem, p.13-4).

O próprio homem sob uma perspectiva de ordem especulativa, na medida em que é objeto de conhecimento para si mesmo, inevitavelmente, por intermédio da apercepção, toma consciência imediata de seu estado, no qual tem de considerar-se por um lado fenômeno, por outro noumenon. Desse modo, afirma Kant (1980, p.277, B 574-5): 
Exclusivamente o homem, que de outra maneira conhece toda a natureza somente através dos sentidos, se conhece a si mesmo também mediante a uma pura apercepção, e isto em ações e determinações internas que de modo algum pode contar como impressões dos sentidos; para si mesmo, ele certamente é, de uma parte, fenômeno, mas de outra, ou seja, no que se refere a certas faculdades, um objeto puramente inteligível porque a sua ação de modo algum pode ser computada na receptividade da sensibilidade. Denominamos estas faculdades de entendimento e razão.

Se um dos pressupostos fundamentais da Crítica da razão pura que reitera a necessidade de tomarmos qualquer objeto de conhecimento sob uma dupla significação ${ }^{7}$ estiver correto, teremos, então, de distinguir entre as representações que nos são dadas de fora e nas quais somos passivos, e as que nós produzimos unicamente de nós mesmos e nas quais demonstramos nossa atividade. Dessa distinção, os objetos têm de ser considerados na mesma relação sob duas perspectivas: ora como fenômenos, quando representados como entes dos sentidos, ora como noumena quando representados como entes inteligíveis.

Visto que o entendimento só pode fazer um uso empírico das categorias, todo conhecimento está restrito àquilo que pode ser objeto de uma experiência possível por intermédio do que nos é dado exteriormente pela sensibilidade, ou seja, a meros fenômenos. Como só podemos ter intuição daquilo que afeta nossa sensibilidade, fica barrado nosso acesso às coisas como são em si mesmas. Mas por de trás daquilo que nos é dado tem de existir algo como causa do efeito perceptível; por isso, temos ao menos de poder pensar nas coisas como são em si mesmas, mesmo sem poder conhecê-las, isto é, temos pelo menos de poder pensar

7 Cf. Kant, 1980, p.16. 
em um objeto transcendental como o fundamento dos fenômenos, mesmo que nada saibamos sobre o que ele seja em si mesmo. Como Kant (1980, p.16, B xxvi-xxvii, grifo do autor) afirma: "será sempre preciso ressalvar que, se não podemos conhecer esses mesmos objetos como coisas em si mesmas, temos pelo menos que poder pensá-los. Do contrário, seguir-se-ia a proposição absurda de haver fenômeno sem que houvesse algo aparecendo".

No entanto, Lebrun (2001, p.61, grifo do autor) adverte: "eu tenho, certamente, o direito, e mesmo o dever, de pensar alguma coisa fora do sensível, mas com a condição de não tomar jamais essa alguma coisa como um ultraobjeto ("Gegenstand"). Tal é a lectio purissima, a mais conforme à "Erkenntnisstheorie" da Crítica".

Por esta razão, o conceito de noumenon, isto é, de uma coisa que não pode ser apreendida como objeto dos sentidos, não é de modo algum contraditório, mas necessário para conter a pretensão natural do entendimento de conhecer as coisas como são em si mesmas.

Tal conceito é, além disso, necessário para não estender a intuição sensível até as coisas em si mesmas e, portanto, para restringir a validez objetiva do conhecimento sensível (pois as demais coisas, que a intuição sensível não alcança, são denominadas noumena, para com isso indicar que aqueles conhecimentos não podem estender a sua região a tudo o que o entendimento pensa). (Kant, 1980, p.160, B 310)

O conceito que o homem faz de si próprio é formado empiricamente a partir do modo como sua consciência é afetada pela receptividade da sensibilidade. No entanto, é preciso ainda admitir a existência de algo que esteja na base do fenômeno, a saber, um noumenon. Neste caso, temos de distinguir entre um caráter empírico e outro inteligível do homem, cuja consequência é a inevitável admissão de um 
Eu empírico correspondente ao conceito que o homem faz de si mesmo a partir dos efeitos perceptíveis pela sensibilidade, e um Eu puro tal como o homem seja constituído em si, ao qual não temos acesso por intuição, e que constitui o fundamento do conceito empírico.

Pois, visto ele não se criar a si mesmo, por assim dizer, e não ter de si um conceito a priori mas sim um conceito recebido empiricamente, é natural que ele só possa também tomar conhecimento de si pelo seu sentido íntimo e consequentemente só pelo fenômeno da sua natureza e pelo modo como a sua consciência é afectada, enquanto que tem de admitir necessariamente, para além desta constituição do seu próprio sujeito composta de meros fenómenos, uma outra coisa ainda que lhe esteja na base, a saber o seu Eu tal como ele seja constituído em si. (Kant, 2005, p.100).

Disso se segue que a constituição do Eu empírico refere-se à parte sensível do sujeito e a tudo aquilo que envolve a sensibilidade do mesmo, ao passo que o Eu puro se refere a sua parte inteligível, isto é, sua parte racional. "Ora o homem encontra realmente em si mesmo uma faculdade pela qual se distingue de todas as outras coisas, e até de si mesmo, na medida em que ele é afectado por objectos; essa faculdade é a razão (Vernunft)" (idem, p.101).

Portanto, se o conhecimento está limitado a meros fenômenos, o homem, ao tomar consciência de si, somente terá acesso àquilo que diz respeito aos efeitos perceptíveis de suas ações, isto é, ao Eu empírico, restando, desse modo, uma parte nele incognoscível, a saber, o Eu puro, imperscrutável pelo entendimento, pois se trata do homem considerado em sua parte numênica. Desse modo, adverte Kant: "Nem a si mesmo e conforme o conhecimento que de si próprio tem por sentido íntimo pode o homem pretender conhecer-se tal como ele é em si” (idem, p.100). 
Notar-se-á, porém, que a classificação dos objetos em geral entre fenômeno, referindo-se ao modo como as coisas nos são dadas, e noumena, referindo-se ao modo como elas são em si mesmas, é assunto discutido pormenorizadamente na primeira Crítica. Entretanto, os efeitos dessa investigação especulativa são imprescindíveis para a elaboração da ética kantiana e, por conseguinte, para atingir o objetivo principal da Fundamentação, a saber, o de encontrar o princípio supremo da moralidade. Mais ainda, demonstra certo enlace entre a filosofia teórica e prática de Kant e apresenta um modo de proceder coerente do sistema crítico, embora os objetos de investigação sejam diferentes.

Desse modo, da distinção entre fenômeno e noumenon sucede ainda outra espécie de divisão importante. Como afirma Kant: "Daqui tem de resultar a distinção, embora grosseira, entre um mundo sensivel e um mundo inteligível, o primeiro dos quais pode variar muito segundo a diferença de sensibilidade dos diversos espectadores, enquanto o segundo, que lhe serve de base, permanece sempre idêntico" (idem, p.100, grifo do autor).

O mundo sensível pode também ser denominado mundo dos fenômenos, no qual nos são dados os objetos que afetam nossa sensibilidade, os únicos que podem ser conhecidos por nosso entendimento. E por estar sujeito à sucessão temporal, tudo no mundo sensível é mutável, pois os objetos sensíveis padecem com o devir. Cada membro do mundo sensível pode observá-lo distintamente, porque segundo a subjetividade, os objetos não afetam todos os sujeitos necessariamente de um mesmo modo. Com relação ao sentimento de prazer e desprazer, por exemplo, pode ocorrer que um dado objeto, ou determinada ação, ao afetar a sensibilidade de um sujeito o envolva em um enorme prazer, ao passo que este mesmo fenômeno ou ação pode a um outro causar imenso desprazer. Assim, o mundo dos 
sentidos pode variar segundo o modo como os objetos afetam a sensibilidade de cada espectador.

Entretanto, para além do dado tem de existir algo que lhe dê sustentação, caso contrário, teríamos de considerar um efeito sem uma causa determinada, o que seria um absurdo segundo a filosofia transcendental. Se o noumenon constitui aquilo que está na base do fenômeno, e se por este conceito Kant define, de modo negativo, como uma coisa enquanto não é objeto de nossa intuição sensível, ${ }^{8}$ então, ele não pode pertencer ao mundo dos sentidos, tendo de estar ligado a outra ordem. Conclui-se que não há incoerência em pensarmos em um mundo dos noumena ou das coisas em si mesmas, o qual Kant denomina de mundo inteligível.

Por inteligível, Kant (1980, p.274, B 566) define "aquilo que num objeto dos sentidos não é propriamente fenômeno". Desse modo, o mundo inteligível nada mais é, porém, do que aquilo que fundamenta o mundo dos sentidos. Ele permanece idêntico a si mesmo, porque, por um lado, os noumena enquanto entes do pensamento, ou seja, como coisas pensadas em si mesmas pela razão, estão fora da ordem temporal e são, por conseguinte, imutáveis. Por outro, a razão é universal e não possui variações no modo como ela é constituída em cada sujeito. Neste sentido, o mundo inteligível diz respeito a tudo aquilo em que está envolvida a razão, com suas leis e princípios.

Considerado sob este duplo ponto de vista, ora sob a perspectiva de sua natureza sensível, ora sob a perspectiva de sua natureza racional, o homem mostra-se pertencer, ao mesmo tempo, como fenômeno, ao mundo dos sentidos, e como noumenon, ao mundo inteligível. Fica demonstrado, desse modo, a existência de um caráter empírico e outro inteligível no homem. Como afirma Allison (1995, p.32):

8 Cf. Kant, 1980, p.158. 
"Sob este ponto de vista, o caráter inteligível é a causa noumênica e o caráter empírico seu efeito fenomênico". ${ }^{9}$ Sendo assim, o caráter inteligível constituir-se-ia como a causa transcendental do caráter empírico.

Neste sentido, o mundo sensível pode ser considerado o todo dos seres sensíveis como fenômenos, ao passo que o mundo inteligível, o todo dos seres racionais como coisas em si mesmas. Do mundo sensível, podemos formar um conceito empírico por intermédio da intuição na medida em que nossa sensibilidade é afetada; já do mundo inteligível, temos apenas uma representação por meio do pensamento, pois ultrapassaríamos o limite estabelecido ao conhecimento humano se quiséssemos perscrutá-lo pela intuição, visto que toda intuição sempre se refere a fenômenos e nunca às coisas como são em si mesmas.

Ao introduzir-se assim pelo pensamento num mundo inteligível, a razão prática não ultrapassa em nada os seus limites; mas ultrapassá-los-ia se quisesse entrar nesse mundo por intuição, por sentimento [...]. O conceito de um mundo inteligível é portanto apenas um ponto de vista que a razão se vê forçada a tomar fora dos fenómenos para se pensar a si mesma como prática, o que não seria possível se as influências da sensibilidade fossem determinantes para o homem, o que porém é necessário na medida em que se lhe não deve negar a consciência de si mesmo como inteligência, por conseguinte como causa racional e actuante pela razão, isto élivremente eficiente. (Kant, 2005, p.110, grifo do autor).

Mas mundos distintos são regulados por princípios distintos, e na medida em que o homem é, ao mesmo tempo, membro participante tanto do mundo sensível quanto do

9 "On this view, the intelligible character to the noumenal cause and the empirical character its phenomenal effect". 
mundo inteligível, a vontade dele parece estar sujeita a dois tipos de legislação. Do sujeito considerado membro do mundo sensível emana, de seu Eu empírico, o princípio egoísta, formado a partir do modo como a subjetividade de cada espectador é afetada pelos fenômenos do mundo e, portanto, válido apenas para a vontade particular de cada sujeito.

Ao mesmo tempo, enquanto membro do mundo inteligível, terá de levar em conta que de seu Eu puro emerge um princípio formal que, por estar fundado na razão, tem de valer para a vontade de todo ente racional. A razão demonstra, desse modo, sua atividade ao fornecer ao homem um princípio oriundo de suas próprias forças, diferentemente da sensibilidade que demonstra sua passividade ao necessitar do mundo empírico na formação de um princípio prático.

Por tudo isto é que um ser racional deve considerar-se a si mesmo, como inteligência (portanto não pelo lado das suas forças inferiores), não como pertencendo ao mundo sensível, mas como pertencendo ao mundo inteligível; tem por conseguinte dois pontos de vista dos quais pode considerar-se a si mesmo e reconhecer leis do uso das suas forças, e portanto de todas as suas acções; o primeiro, enquanto pertencente ao mundo sensível, sob leis naturais (heteronomia); o segundo, como pertencente ao mundo inteligível, sob leis que, independentes da natureza, não são empíricas, mas fundadas somente na razão (Kant, 2005, p.102, grifo do autor).

Portanto, na consciência de si o homem se vê como um ser que é ao mesmo tempo racional e sensível, ou seja, como um ente cindido entre duas partes heterogêneas. Por conseguinte, a vontade humana está diante de duas fontes distintas de determinação, ela está "colocada entre o seu princípio a priori, que é formal, e o seu móbil a posteriori, que é material, por assim dizer numa encruzilhada" (idem, 
p.30). O primeiro reside na razão, ao passo que o segundo na sensibilidade.

Em face desta encruzilhada, nasce uma dialética natural, ${ }^{10}$ a partir da qual o homem tem de contrastar entre dois princípios distintos e decidir entre duas possibilidades: se determina a vontade exclusivamente conforme o princípio racional ou se se deixa seduzir pelas solicitações do desejo sensível e determina a vontade segundo o princípio egoísta. Notar-se-á, porém, que é justamente esta ambivalência entre princípios práticos que permite ao homem pertencer ao que chamamos de espécie humana, porque se a vontade do homem fosse determinada apenas por seu caráter empírico, ou somente por seu caráter inteligível, consequentemente, ele não seria um ser humano. Axinn (1981, p.170, tradução nossa) afirma que:

A 'dialética natural' de Kant consiste na oposição entre estes dois princípios. É importante entender que se houvesse a falta de algum deles, nós não teríamos um ser humano. $\mathrm{O}$ princípio moral, somente, produziria um anjo; só o principio egoísta nos tornaria um diabo. Para a situação moral, nos termos de Kant, nós devemos ter essa ambivalência entre esses dois princípios. ${ }^{11}$

Portanto, por conta do homem estar cindido entre razão e sensibilidade, a vontade humana pode ser motivada tanto por estímulos empíricos fundados no modo como a sensibilidade é afetada e que constituem, por assim dizer,

10 Cf. Kant, 2005, p.37.

11 'Kant's 'natural dialectic' consists in the opposition between these two principles. It is important to understand that if either on were missing, we would not have a human being. The moral principle, alone, would produce an angel; the selfish principle, alone, would give us a devil. For the moral situation, in Kant's terms, we must have this ambivalence between the two principles." 
o princípio egoísta, quanto por um elemento puro produzido pela razão, isto é, pelo princípio formal. Todavia, se na ética kantiana o comportamento humano carece de um princípio de conduta válido para todo ente, do qual depende também a produção de uma boa vontade, a investigação terá de proceder no exame dos princípios práticos que emanam da razão, tanto os que se originam totalmente a priori, quanto aqueles fundados na sensibilidade, e tornar claro o modo como eles se relacionam no processo de determinação da vontade, para, então, descobrir qual destes princípios possa valer universalmente e seja capaz de formar uma boa vontade. 



\section{2 \\ Os PRINCÍPIOS DA RAZÃO PRÁTICA}

Por conta da necessidade de observarmos o homem sob um duplo ponto de vista, ora em sua parte empírica como fenômeno, ora em sua parte pura como noumenon, encontramos nele de um lado a sensibilidade, e de outro a razão. Da primeira emergem as inclinações, ao passo que da segunda, em oposição às inclinações, o dever. Da razão e do dever brota ainda a lei moral, que se opõe firmemente ao desejo de felicidade do homem estritamente fundado na sensibilidade. Diante deste quadro, faz-se necessário traçar a distinção entre o princípio formal racional do princípio material sensível para verificar se a razão prática pura é suficientemente capaz de determinar objetivamente a vontade de todo ente racional. Esta é a tarefa que pretendemos desempenhar neste capítulo.

\section{Dever, inclinação e felicidade}

Para Kant, a razão prática pura apresenta-se como o único e exclusivo fundamento para a moral, nenhum outro é suficientemente capaz de impor, totalmente a priori, à 
vontade humana uma lei válida objetivamente à conduta de todo ente racional. Mas, como Höffe (1986, p.159, tradução nossa) adverte, este tipo de concepção sobre o fundamento da ética distingue-se absolutamente de qualquer investigação moral empreendida anteriormente:

Antes de Kant se buscou a origem da ética na ordem da natureza ou da comunidade humana, na aspiração à felicidade, na vontade de Deus ou no sentimento moral. Kant pretende mostrar que não cabe explicar desse modo o caráter objetivo que a moralidade reclama para si. Como no campo teórico, no campo prático só é possível a objetividade por intermédio do sujeito. ${ }^{1}$

Segundo Kant, a necessidade de que a razão seja o fundamento de uma boa vontade incide sobre uma explicação teleológica da constituição do homem pela Natureza. Para compreender o argumento kantiano, teremos de considerar que a Natureza agiu com acerto nas repartições e talentos de um ser organizado constituído com vistas a realizar certo fim que é a vida. E também aceitar como princípio que neste ser não se encontra nenhum órgão que não seja apropriado para a consecução deste fim. Podemos conjeturar a partir disso que se o homem fosse dotado pela Natureza apenas de sensibilidade, a vida destinar-se-ia à satisfação plena do conjunto de suas inclinações, isto é, do gozo e da felicidade. No entanto, pelo fato de o homem possuir, além da sensibilidade, a razão, e considerando que a Natureza tenha agido com acerto na repartição das faculdades,

1 “Antes de Kant se buscó el origen de la ética en el orden de la naturaleza o de la comunidad humana, en la aspiración a la felicidad, en la voluntad de Dios o en el sentido moral. Kant intenta mostrar que no cabe explicar de ese modo el carácter objetivo que la moralidad reclama para sí. Como en el campo teórico, en el campo práctico sólo es posible la objetividad por intermedio del sujeto." 
podemos concluir que a vida destinou ao homem outra intenção de existência que não se resume apenas à satisfação de seus desejos. Este outro modo de existência é para Kant (2005, p.25, grifo do autor) a moralidade.

Se, no entanto, a razão nos foi dada como faculdade prática, isto é, como faculdade que deve exercer influência sobre a vontade, então o seu verdadeiro destino deverá ser produzir uma vontade, não só boa quiçá como meio para outra intenção, mas uma vontade boa em si mesma, para o que a razão era absolutamente necessária, uma vez que a natureza de resto agiu em tudo com acerto na repartição das suas faculdades e talentos.

A sensibilidade, portanto, é incapaz de produzir uma boa vontade compreendida como bem irrestrito ou incondicionado, visto que a vontade determinada por motivos empíricos está sempre condicionada ao objeto desejado, e o desejo é produzido pela forma como o objeto afeta a subjetividade de cada sujeito. A boa vontade necessita da razão como condição de sua possibilidade, pois a sensibilidade faz da vontade um mero instrumento para satisfazer os fins da inclinação e, deste modo, condiciona-a a um fim que, por sua vez, restringe a ação à consecução da felicidade. No entanto, a boa vontade não é boa por aquilo que ela promove, mas simplesmente pelo que é em si mesma.

Contudo, o princípio formal oriundo da razão não é reconhecido imediatamente como fundamento suficiente de determinação da vontade, pois, além da natureza racional, o homem possui ainda uma natureza sensível, representada por um conjunto de inclinações cuja principal característica é a insaciabilidade. O caráter empírico do homem representado pelo desejo sensível e a procura incessante pela satisfação das inclinações constituem, assim, um grande obstáculo ao desenvolvimento pleno de sua racionalida- 
de, isto é, de seu caráter inteligível e, por conseguinte, da moralidade. Como afirma Rohden (2003, p.xv):

É certamente verdade que o homem não apenas possui uma razão mas também a é. Só que ele não se identifica imediatamente com ela, por ter também corpo e inclinações, as quais possuem como característica dominante sua insaciabilidade e constituem como tais um constante desafio ao domínio da razão.

Todavia, se na ética kantiana o comportamento humano carece de um princípio de conduta válido para a vontade de todo ente, e se este princípio é racional, então, uma ação para ser realizada de modo moral exige a coerção da razão frente às inclinações sensíveis. Para a produção de uma boa vontade, cujo valor é absoluto e que se constitui como condição do valor atribuído a todo o restante das coisas, o arbítrio tem de determinar a vontade segundo os princípios da razão, pois a sensibilidade é incapaz de fornecer a ideia de um bem incondicionado por ela estar intimamente relacionada àquilo que diz respeito ao agradável segundo a experiência subjetiva de cada sujeito. E no âmbito das ações humanas, "o que constitui o valor particular de uma vontade absolutamente boa, valor superior a todo preço, é que o princípio de acção seja livre de todas as influências de motivos contingentes que só a experiência pode fornecer" (Kant, 2005, p.65). Temos, portanto, de determinar qual seja este princípio.

Para Kant não há outro senão o princípio do Dever, "que contém em si o de boa vontade, posto que sob certas limitações e obstáculos subjectivos, limitações e obstáculos esses que, muito longe de ocultarem e tornarem irreconhecível a boa vontade, a fazem antes ressaltar por contraste e brilhar com luz mais clara" (idem, p.26). Se para explicarmos a noção de boa vontade temos de recorrer ao 
conceito de dever, então podemos compreender que na ética kantiana o bem e o dever estão intimamente ligados, sem os quais não se poderia formar a ideia de uma ação moral. Como afirma Paton (1971, p.45, tradução nossa):

Kant é comumente considerado o apóstolo do dever, de modo que para que nós compreendamos sua doutrina em perspectivas reais, devemos nos lembrar que para ele, a bondade é fundamental; e não há motivo para supor que ele tenha considerado a concepção de dever separada da bondade. ${ }^{2}$

Vale observar que, inevitavelmente, todo homem, quando diante de uma situação que exija escolha, faz para si a pergunta: o que devo fazer para bem conduzir minha ação? ${ }^{3}$ Está subjacente à pergunta a busca por uma regra de conduta capaz de fornecer ao arbítrio subsídio para que a escolha seja da melhor ação a praticar. Isso demonstra que o homem possui a noção do dever, por isso, Kant afirma ser o dever um conceito popular, ao alcance do entendimento do homem comum.

É, portanto, no próprio sujeito de modo totalmente a priori, que Kant encontrará o princípio moral, pois se a pergunta acerca do que deve ser feito tem origem no ho-

2 "Kant is so commonly regarded as the apostle of duty that if we are to get his doctrine in true perspective we must remember that for him goodness is fundamental; and there is no warrant for supposing that he even entertained the conception of a duty divorced from goodness."

3 Kant afirma que esta pergunta constitui umas das três questões para as quais está voltado todo interesse de nossa razão: "Todo interesse de minha razão (tanto o especulativo quanto o prático) concentrase nas três seguintes perguntas: 1. Que posso saber? 2. Que devo fazer? 3. Que me é permitido esperar?" (Kant, 1980, p.393, B 832-3, grifo do autor). A primeira pergunta é puramente especulativa, a segunda prática, a terceira, por sua vez, é concomitantemente teórica e prática. 
mem, a resposta tem que dele provir, visto que "o conhecimento daquilo que cada homem deve fazer, e por conseguinte saber, é também pertença de cada homem, mesmo do mais vulgar" (Kant, 2005, p.36). E tanto para o homem mais vulgar quanto para o mais culto, a noção de boa vontade, fundada no princípio do dever, é aquela que se apresenta como regra de conduta moral.

Neste contexto, a vontade humana, quando diante de uma situação que exija escolha, fica diante de uma encruzilhada, na qual tem de decidir se se determina conforme as exigências da razão ou se se deixa conduzir pelas solicitações da sensibilidade. Desse modo, a ação escolhida pelo sujeito agente pode ocorrer como sendo boa do ponto de vista moral, quando motivada por princípios da razão, ou a melhor ação produzida para saciar o desejo, quando motivada por estímulos sensíveis.

As nossas ações podem, portanto, ser consideradas sob um duplo ponto de vista: ou de uma vontade absolutamente conforme a razão ou de uma vontade afetada pelas inclinações. Não há, no entanto, nenhuma contradição, mas apenas uma resistência das inclinações às prescrições da razão.

É preciso, porém, fazer aqui uma advertência. Embora Kant não tenha abordado de modo mais profundo no texto da Fundamentação a distinção entre uma razão prática pura e uma razão prática empírica, tarefa destinada à segunda Crítica, faz-se necessário que tenhamos claro esta distinção para não incorrer no erro de pensar a existência de uma vontade determinada imediatamente por móbiles empíricos. Vale notar que toda escolha é racional, pois do contrário poderíamos afirmar de modo absurdo a existência de ações produzidas pelo acaso ou por determinações externas ao arbítrio de cada sujeito. Se assim fosse, isto é, se para as escolhas não houvesse razão suficiente, não poderíamos imputar responsabilidade moral ao sujeito agen- 
te, pois a liberdade estaria fundada na indiferença e cada ação possuiria, desse modo, o mesmo valor. ${ }^{4}$

Todavia, a razão pode tanto produzir uma vontade boa para satisfazer os fins da inclinação, isto é, boa para a realização da felicidade, sendo a vontade neste caso um mero instrumento, quanto pode produzir uma vontade boa em si mesma. Como diz Paton(1971, p.45, tradução nossa): "é desejável notar que há essas duas funções distintas da razão, e que ambas almejam o bem. A primeira função visa a um bem condicionado (isto é, a felicidade), e a segunda a um bem incondicionado (isto é, a boa vontade)". ${ }^{5}$

Mas, se por um lado o essencial para a moralidade depende de que o princípio a priori constitua o fundamento determinante da vontade, por outro, as inclinações apresentam-se como um forte obstáculo às prescrições da razão. Como afirma Kant (2005, p.37):

O homem sente em si mesmo um forte contrapeso contra todos os mandamentos do dever que a razão lhe representa como tão dignos de respeito: são as suas necessidades e inclinações, cuja total satisfação ele resume sob o nome de felicidade.

Kant define inclinação do seguinte modo: "Chama-se inclinação a dependência em que a faculdade de desejar está em face das sensações; a inclinação prova sempre, portanto, uma necessidade (Bedürfnis)" (idem, p.49, nota, grifo do autor). Esta necessidade se dá pelo fato de a faculdade de desejar estar sempre desejando algo, em função de a insaciabilidade constituir-se como sua característica predomi-

4 Cf. Allison, 1995, p.136-7.

5 "it is desirable to note that there are these two distinct functions of reason, and that both aim at a good, the first function at a conditioned good (namely, happiness), and the second at an unconditioned good (namely, a good will)." 
nante. Para Allison (1995, p.108, tradução nossa), "a inclinação é meramente uma espécie de desejo e, portanto, aquela ação aus Neigung é somente uma espécie de ação baseada no desejo". ${ }^{6}$

A felicidade, por sua vez, diz respeito à satisfação do conjunto de inclinações sensíveis. E Kant (2003, p.85) deixará claro na segunda Crítica o seguinte ponto: "Ser felizé necessariamente a aspiração de todo ente racional, porém, finito e, portanto, um inevitável fundamento determinante de sua faculdade de apetição”.

Sucede, porém, que o conceito de felicidade é indeterminado e, apesar de todo homem desejar ser feliz, ninguém é capaz de dizer, certamente, o que deseja e quer, porque todos os elementos que pertencem à felicidade são empíricos, isto é, têm de ser tirados da experiência. Para a ideia de felicidade, é necessário um todo absoluto, um máximo de bem-estar, quer no presente, quer no futuro. E nenhum ente finito é capaz de determinar com exatidão o que realmente o faria feliz: se a riqueza, o conhecimento, a saúde, a honra; pois para se saber o que lhe traria o máximo de bemestar em um estado duradouro seria preciso a onisciência. Desse modo, diz Kant, "o problema de determinar certa e universalmente qual acção poderá assegurar a felicidade de um ser racional, é totalmente insolúvel” (2005, p.55).

Mas caso a intenção do homem fosse exclusivamente satisfazer a totalidade de suas inclinações e deste modo atingir a felicidade por intermédio da razão, ele estaria fazendo dela um uso inadequado, pois se a razão tem de exercer alguma influência sobre a vontade, ela está destinada a subordinar a intenção privada do homem a uma outra intenção de existência, a saber, torná-lo digno de ser feliz por

6 Para Allison, "inclination is merely one species of desire and, therefore, that action aus Neigung is itself only one species of desirebased action. 
meio da moralidade. Para Paton (1971, p.44, tradução nossa): "A verdadeira função da razão, no seu aspecto prático, deve ser produzir uma boa vontade não como meio para outra coisa, como a felicidade, mas boa absolutamente em si mesma". ${ }^{7}$ E, como afirma Kant na Fundamentação, "assim a boa vontade parece constituir a condição indispensável do próprio facto de sermos dignos da felicidade" (Kant, 2005, p.22).

Temos a seguinte equação: quanto mais o homem se deixa conduzir pelos princípios da razão prática pura, mais ele se afasta de suas inclinações como a principal fonte dos motivos determinantes da vontade, tornando-se, desse modo, cada vez mais um ente moral. Consequentemente, o desejo de felicidade dá lugar ao merecimento de ser feliz. Com efeito, como adverte Paton (1971, p.57, tradução nossa), na ética kantiana ainda existe a possibilidade de o homem ser feliz: "Com relação a alguma indicação de que, sobre a visão de Kant, um homem bom deve ser sempre infeliz, isto é puramente sem sentido. Ele sempre insiste que a vida moral traz com ela sua própria satisfação ou contentamento (Zufriedenheit) peculiar". ${ }^{8}$

Para Kant (2005, p.26), agir sob as prescrições da razão também pode trazer um certo tipo de contentamento, embora diferente daquilo que se entende por felicidade, isto é, a satisfação de todas as inclinações. Diz ele:

Porque a razão, que reconhece o seu supremo destino prático na fundação duma boa vontade, ao alcançar esta intenção

7 "The true function of reason on its practical side must be to produce a will good not as a means to something else such as happiness, but good absolutely and in itself."

8 "As to any suggestion that on Kant's view a good man must always be unhappy, this is pure nonsense. He always insists that the moral life brings with it its own peculiar satisfaction or contentment (Zufriedenheit)." 
é capaz duma só satisfação conforme à sua própria índole, isto é a que pode achar ao atingir um fim que só ela (a razão) determina, ainda que isto possa estar ligado a muito dano causado aos fins da inclinação.

Desse modo, por conta da felicidade estabelecer-se como um conceito indeterminado, e em função da contingência das inclinações, o conceito do dever, que contém em si o de boa vontade, torna-se condição fundamental para nos tornar dignos de felicidade ou de nos dar satisfação moral.

Na Fundamentação, Kant (2005, p.31, grifo do autor) define o dever como "a necessidade de uma ação por respeito à lei. Pelo objecto, como efeito da acção em vista, posso eu sentir em verdade inclinação, mas nunca respeito, exactamente porque é simplesmente um efeito e não a actividade de uma vontade”. Temos de respeitar a lei por se tratar de um produto da atividade da vontade de um ente racional.

A vontade, na medida em que é determinada pelo arbítrio, efetua no mundo sensível três tipos de ações: aquelas que são contrárias ao dever (imorais), aquelas que são conformes ao dever (legais); e as que são propriamente efetuadas por dever (morais).

As ações totalmente contrárias ao dever são facilmente identificáveis pela ausência de qualquer relação com a lei moral na determinação da vontade. Por exemplo: mentir constitui-se como uma ação contrária ao dever, porque a máxima que determina a vontade neste caso não pode ser elevada a lei prática universal. Já as ações conformes ao dever podem conter legalidade, porém, estão desprovidas de moralidade, porque elas estão de acordo com a letra da lei, mas não são impulsionadas por seu espírito. Dirá Kant (2003, p.249, nota, grifo do autor) na segunda Crítica: "Pode-se dizer de cada ação conforme à lei, que, contudo, 
não ocorreu por causa da lei, que ela seja moralmente boa apenas segundo a letra, mas não segundo o espírito (segundo a disposição)". No caso de uma ação conforme ao dever, na medida em que foi efetivada pelo arbítrio, ela pode conter legalidade porque em sua realização a máxima se eleva à lei, isto é, a um imperativo, mesmo sendo ele hipotético.

Exemplifiquemos:

Quando a vida humana é conservada por puro respeito à vida, pode-se dizer que o princípio determinante da vontade é o estrito dever e, portanto, a ação tem conteúdo moral; se, pelo contrário, a vida é conservada apenas por inclinação, por egoísmo, a máxima não tem conteúdo moral e a vida é conservada apenas conforme ao dever.

Praticar a caridade é um dever; todavia, se ela é praticada tendo em vista o louvor e as honras, então é praticada não por dever, mas conforme ao dever (por egoísmo e inclinação). Mas se nenhuma inclinação estimulasse a ação, ou seja, se ela fosse praticada pelo puro dever, então ela teria um autêntico valor moral.

Tendo em vista que ser justo é um dever, o merceeiro pode colocar o preço justo por três razões: pode ser por simpatia a seus clientes; pode ser para conseguir a estima deles; ou por fim, segundo sua consciência do estrito dever. No primeiro caso, porém, a ação é conforme ao dever, mas o é por inclinação, pois está fundada na inclinação para a simpatia. No segundo, o merceeiro age para obter valor na opinião dos outros e, portanto, apenas por interesse egoísta, pois a justiça está sendo considerada um meio para se atingir um fim determinado. Como afirma Tugendhat (1996, p.119):

Apenas de acordo com o dever age, p.ex., o comerciante - assim o exemplo de Kant - que atende sua clientela honestamente, mas não por causa de 'princípios da honestidade' e por isto não 'por dever', senão 'com propósito egoísta'. Esta 
é a motivação do contratualista. Ele quer aparecer de forma honesta, porque isto lhe é vantajoso.

A terceira razão pode ser o estrito dever que ele tem, segundo sua disposição moral, de levar a seus clientes o preço justo. Esta ação, segundo o ponto de vista kantiano, é a única que contém valor moral positivo, pois as outras ações podem até merecer louvor por não contrariarem o dever, mas, porque são realizadas por inclinação ou interesse egoísta, não merecem ser estimadas.

Pois que aquilo que deve ser moralmente bom não basta que seja conforme à lei moral, mas tem também que cumprirse por amor dessa mesma lei; caso contrário, aquela conformidade será apenas muito contingente e incerta, porque o princípio imoral produzira na verdade de vez em quando acções conformes a lei moral, mas vezes ainda acções contrárias a essa lei. (Kant, 2005, p.16, grifo do autor)

Assegurar cada qual sua própria felicidade é um dever, mas mesmo sem considerá-lo como tal, todo homem, como já foi visto, tem por si só um forte desejo de ser feliz. E em vista da indeterminação do conceito de felicidade, é necessário que o homem procure ser feliz por dever, sem deixarse dominar pelas inclinações, pois somente assim o seu comportamento tem propriamente valor moral, já que a verdadeira felicidade, segundo Kant, consiste no domínio dos instintos, das inclinações naturais, no afastamento de todo o determinismo natural.

Daqui se infere que somente as ações praticadas por dever têm conteúdo moral, pois somente neste caso o princípio formal do querer é moral e pode determinar, por conseguinte, ações morais. Deste modo, conclui-se que a vontade tem de ser determinada objetivamente pela lei e subjetivamente pelo puro respeito à lei para ser considera- 
da boa, sem restrição, pois o bem tem de ser praticado por dever e não por inclinação.

\section{Lei moral e máxima}

Se uma ação realizada por dever tem de eliminar a influência da inclinação e todo elemento empírico que possa tornar-se objeto da vontade, e sendo o dever a necessidade de realização de uma ação por respeito à lei moral, logo Kant conclui que "nada mais resta à vontade que a possa determinar do que a lei objectivamente, e, subjectivamente, o puro respeito por esta lei prática, e por conseguinte a máxima que manda obedecer a essa lei, mesmo com prejuízo de todas as minhas inclinações" (Kant, 2005, p.31, grifo do autor).

Desse modo, a vontade encontra-se, por assim dizer, diante de dois princípios de determinação, um subjetivo, outro objetivo, aos quais Kant (idem, p.58, nota, grifo do autor). denomina respectivamente em seus termos de máxima e lei, ao mesmo tempo em que traça uma distinção entre eles:

Máxima é o princípio subjectivo da acção e tem de se distinguir do princípio objectivo, quer dizer da lei prática. Aquela contém a regra prática que determina a razão em conformidade com as condições do sujeito (muitas vezes em conformidade com a sua ignorância ou as suas inclinações), e é portanto o princípio segundo o qual o sujeito age; a lei, porém, é o princípio objectivo, válido para todo o ser racional, princípio segundo o qual ele deve agir, quer dizer um imperativo.

A máxima, portanto, constitui-se como uma espécie particular de princípio, que pode ser definida como o princípio subjetivo de toda ação de um agente racional. O princípio subjetivo é empírico quando estiver estritamente re- 
lacionado ao sentimento de prazer ou desprazer que a representação do objeto apetecido causa no sujeito na determinação da vontade.

Estes princípios empíricos são subjetivos, porque o prazer da ação desejada diz respeito à receptividade do sujeito, isto é, à sensação que esta ação causa em cada um. Uma ação capaz de proporcionar prazer a determinado sujeito pode, concomitantemente, causar desprazer a outro. As máximas fundadas em inclinações sensíveis, isto é, empíricas, são denominadas por Kant de máximas materiais, porque são dependentes de um desejado fim que a ação pretende atingir, que acaba por se tornar a matéria da máxima.

Mas, muito embora as máximas tenham comumente como fundamento a sensibilidade, disso não se pode concluir a impossibilidade de existirem máximas fundadas totalmente a priori na razão, isto é, que não dependam do desejo ou das inclinações para se constituírem como princípios subjetivos, as quais pudessem ser denominadas de máximas formais. Como Paton (1971, p.61, tradução nossa) adverte: "É de toda importância reconhecer que embora as máximas sejam comumente fundadas em inclinações [...], pode, não obstante, ser possível agir sob máximas que não estejam fundadas deste modo". ${ }^{9}$

Para tanto, é preciso pensar uma máxima que esteja desprovida de qualquer relação com um objeto sensível ou com uma ação desejada. Segundo Paton, quando excluímos todo elemento empírico de uma máxima, ela pode tornarse apenas a máxima formal de seguir a lei moral. ${ }^{10}$

9 "It is all-important to recognize that while maxims are commonly based on inclinations [...], it may nevertheless be possible to act on maxims which are not so based."

10 Cf. Paton, 1971, p.72. 
As máximas materiais são um produto da razão prática trabalhando a serviço das inclinações, ao passo que uma máxima formal estaria em função do estrito dever. Portanto, toda máxima, seja ela material, seja ela formal, é derivada da razão, que é, por excelência, (como Kant denomina na primeira Crítica) a faculdade dos princípios. ${ }^{11} \mathrm{~A}$ sensibilidade fornece apenas a matéria, pois, se alguma máxima se originasse estritamente dela, a ação realizada teria de ser considerada irracional, eliminando a possibilidade de imputarmos responsabilidade ao sujeito agente.

A vontade, no entanto, é sempre determinada por uma máxima; deste modo nossas ações estão fundadas, inevitavelmente, em princípios subjetivos materiais ou formais. Mas se uma ação realizada por dever tem de estar desprovida de todo elemento empírico, podemos concluir que a máxima de uma ação moral tem de ser formal e não material, dado que os princípios práticos materiais são insuficientes para transformarem-se em leis objetivas.

Uma acção praticada por dever tem o seu valor moral, não no propósito que com ela se quer atingir, mas na máxima que a determina; não depende portanto da realidade do objecto da acção, mas somente do princípio do querer segundo o qual a acção, abstraindo de todos os objectos da faculdade de desejar, foi praticada. (Kant, 2005, p.30, grifo do autor)

Se para ser boa a vontade tem de ser determinada pelo bem incondicionado e se o praticamente bom é aquilo que determina a vontade por meio de representações da razão, então, para que o conceito popular de boa vontade obtenha autenticidade e universalidade, ele terá de repousar em princípios da razão prática pura, pois se a razão for incapaz de constituir o fundamento deste juízo, o homem terá dian-

11 Cf. Kant, 1980, p.180. 
te de si um preceito ou uma regra prática, mas nunca uma lei moral que valha necessariamente para todo ente racional.

Toda a gente tem de confessar que uma lei que tenha de valer moralmente, isto é como fundamento duma obrigação, tem de ter em si uma necessidade absoluta. [...] por conseguinte, o princípio da obrigação não se há-de buscar aqui na natureza do homem ou nas circunstâncias do mundo em que o homem está posto, mas sim a priori exclusivamente nos conceitos da razão pura, e que qualquer outro preceito baseado em princípios da simples experiência, e mesmo um preceito em certa medida universal, se ele se apoiar em princípios empíricos, num mínimo que seja, talvez apenas por um só móbil, poderá chamar-se na verdade uma regra prática, mas nunca uma lei moral. (idem, p.15-6).

Para determinarmos se da razão pode emergir algum princípio prático, a investigação tem de proceder no âmbito de uma Metafísica dos Costumes, pois a lei moral, para ser válida a todo ente racional em geral, deve ser deduzida do conceito universal de um ser racional, não de um conceito empírico aduzido a partir de uma Antropologia. O princípio moral de que se parte para fundar uma moral não pode estar fundado em particularidades da natureza humana, porque ele deve existir por si mesmo, independente da existência do homem. Tampouco podem as regras morais serem fornecidas pela experiência, o que Kant (1980, p.188, grifo do autor B 375) já alertava na primeira Crítica:

Com efeito, relativamente à natureza a experiência fornece-nos a regra e é a fonte da verdade; porém, no que concerne às leis morais, a experiência é (infelizmente) a mão da ilusão; e é sumamente reprovável tirar as leis sobre o que devo fazer daquilo que é feito ou querer limitar a primeira coisa pela segunda. 
Partindo dessas premissas temos de concluir com Kant (2005, p.46) que "todos os conceitos morais têm sua sede e origem complemente a priori na razão, e isto tanto na razão humana mais vulgar como na especulativa em mais alta medida; que não podem ser abstraídos de nenhum conhecimento empírico e por conseguinte puramente contingente".

Desse modo, se a Metafísica da Natureza tem de determinar a priori as leis segundo as quais tudo acontece, uma Metafísica dos Costumes terá assim de determinar a lei segundo a qual tudo deve acontecer, mas ponderando também as condições sob as quais muitas vezes não acontece o que deveria acontecer. ${ }^{12}$ É um pressuposto fundamental do sistema crítico a ideia da existência de leis tanto da natureza, quanto da conduta humana. Como diz Kant (2005, p.47): "Tudo na natureza age segundo leis"; o que nos distingue dos outros animais e das demais coisas do mundo é que "Só um ser racional tem a capacidade de agir segundo a representação das leis, isto é, segundo princípios, ou: só ele tem uma vontade" (idem, grifo do autor).

Nossa conduta, portanto, se distingue do comportamento dos animais por conta de podermos agir conforme princípios, isto é, pela nossa capacidade de podermos ponderar sobre qual princípio devemos nos apoiar ou deixar de lado na realização de uma determinada ação.

12 É neste ponto, quando da noção comum do dever se extrai o conceito altamente abstrato de lei, que ocorre na Fundamentação a "Transição da filosofia moral popular para a Metafísica dos Costumes", um passo importante para encontrar o fundamento da moralidade. Como afirma Kant: "Este facto de descer até aos conceitos populares é sem dúvida muito louvável, contanto que se tenha começado por subir até aos princípios da razão pura e se tenha alcançado plena satisfação neste ponto; isto significaria primeiro o fundamento da doutrina dos costumes na metafísica, para depois, uma vez ela afirmada solidamente, a tornar acessivel pela popularidade" (Kant, 2005, p.43). 
Na reflexão acerca do que deve ser feito ou deixado de fazer, o homem sempre determina a vontade a partir de princípios subjetivos que podem estar ou não em conformidade com princípios objetivos. Disso se segue que todas as ações humanas estão fundadas em máximas, sejam elas conformes ou não à lei.

Mas, é importante frisar que somente um agente racional age sob máximas. Se eu resolvo cometer suicídio porque acredito cegamente que minha vida oferece mais sofrimento do que prazer, minha ação está fundada na seguinte máxima: se a vida oferece mais sofrimento do que prazer, devemos cometer suicídio. Como Paton (1971, p.60, tradução nossa) diz: "Minha máxima é o princípio no qual está de fato o fundamento determinante da minha ação; mas ela não pretende, como um princípio objetivo, ser válida para qualquer outra pessoa, e ela pode ser boa ou pode ser má”. ${ }^{13}$ Um animal irracional, caso viesse a dar cabo da própria vida, cometeria este ato simplesmente por instinto, mas nunca fundado em um princípio determinante da vontade.

Contudo, é preciso ter claro que tudo o que derive da disposição natural, de sentimentos ou tendências e que não possa ser universalizado, pode constituir-se como uma máxima, mas nunca como uma lei, porque ela acaba nos dando um princípio subjetivo segundo o qual regulamos nossa ação, mas não um princípio objetivo válido para a ação de todo ente racional. A máxima pode admitir elementos empíricos, ao passo que a lei tem de ser pura para valer universalmente de modo incondicionado.

Tudo o que [...] derive da disposição natural particular da humanidade, de certos sentimentos e tendências, mesmo até,

13 "My maxim is the principle which is in fact the determining ground of my action; but it does not profess, like an objective principle, to be valid for any one else, and may be good, or it may be evil." 
se possível, duma propensão especial que seja própria da razão humana e não tenha que valer necessariamente para a vontade de todo o ser racional, tudo isso pode na verdade dar lugar para nós a uma máxima, mas não a uma lei; pode darnos um princípio subjectivo segundo o qual poderemos agir por queda ou tendência, mas não um princípio objectivo que nos mande agir mesmo a despeito de todas as tendências, inclinações e disposições naturais. (Kant, 2005, p.64, grifo do autor).

Ser feliz é a aspiração de todo ente racional, mas a máxima sob a qual age o sujeito em busca da felicidade vale somente para sua vontade particular, enquanto satisfação de um conjunto de inclinações. Se a satisfação das inclinações de um determinado sujeito está na conquista da riqueza material, a máxima que irá fundamentar sua ação é a seguinte: para ser feliz devo agir com vistas a me tornar rico. Desse modo, Paton (1971, p.60, grifo do autor, tradução nossa) afirma:

Princípios subjetivos são válidos somente para o sujeito ou agente particular como princípios sob os quais ele escolhe para agir. Contra estes, nós temos 'princípios objetivos'; que são princípios sob os quais qualquer agente racional poderia agir se a razão dominasse completamente seu desejo. Desse modo, princípios objetivos são válidos para todo agente racional, e eles podem ser chamados de 'princípios da razão'. ${ }^{14}$

Mas, se o que traz satisfação a um sujeito pode não trazer para outro, segue-se daqui a impossibilidade de fazer

14 "Subjective principles are valid only for the individual subject or agent as the principles on which he chooses to act. Against these we must set 'objective principles'; that is, principles on which any rational agent would act if reason had full control over his passion. Objective principles are thus valid for every rational agent, and they may be called 'principles of reason'." 
dessa máxima uma lei, dada a contingência da qual ela provém. Uma lei, portanto, não é suficientemente capaz de dizer o que devemos fazer para sermos felizes, mas apenas o que devemos fazer para nos tornarmos dignos de felicidade. Kant (1980, p.393, grifo do autor B 834) já havia atentado para este fato, já na primeira Crítica, onde ele diz: "Denomino pragmática (regra de prudência) a lei prática derivada da motivação da felicidade; por outro lado, intitulo moral (lei da moralidade) aquela lei, se é que existe, que nada mais possui como motivação do que o merecimento de ser feliz". Se assim for, então toda ação motivada pelo desejo de felicidade não pode possuir valor moral algum, pois a vontade neste caso foi determinada por uma regra de prudência e não pela lei moral.

A lei é, por sua vez, um produto da razão representada a partir de meros conceitos, ou seja, sem mesclas com o empírico e, portanto, um princípio válido objetivamente. Mas que lei é esta que tem de determinar a vontade para que esta possa ser considerada boa absolutamente? Kant a define do seguinte modo (primeira fórmula do imperativo categórico, a fórmula universal): "devo proceder sempre de maneira que eu possa querer também que a minha máxima se torne uma lei universal" (Kant, 2005, p.33, grifo do autor).

No entanto, embora Kant descreva e trace as características necessárias de uma lei moral capaz de valer universalmente, uma questão fica insolúvel na Fundamentação. ${ }^{15}$ Trata-se de poder provar que essa lei possui validade para a vontade humana, o que de fato ocorrerá na Crítica da razão prática, ${ }^{16}$ quando Kant mostra que a lei objetiva se impõe à vontade humana como um factum da razão pura prática e, 
desse modo, rejeita a possibilidade de um factum antropológico, que seria, por sua vez, naturalizar o transcendental.

Mas poder querer que uma máxima se transforme em lei universal é o critério que permite julgar moralmente as ações humanas, e com isso, diz Kant (idem, p.62, grifo do autor), está perfeitamente de acordo o homem de entendimento vulgar, que tem sempre diante dos olhos este princípio em seus juízos práticos. "Temos que poder querer que uma máxima da nossa acção se transforme em lei universal: é este o cânone pelo qual a julgamos moralmente em geral”. Segundo Paton (1971, p.73, tradução nossa), este é um padrão de avaliação essencial para fundar a moral: "Julgar nossas próprias ações pela mesma norma universal que nós aplicamos às ações dos outros é uma condição essencial da moralidade". ${ }^{17}$

No entanto, nem sempre nossas ações estão fundadas em princípios objetivos, isto é, nem sempre nossas máximas são de tal modo constituídas que possam ser elevadas à lei universal. Para examinar se a máxima está em conformidade com a lei, verifiquemos se ela não entra em contradição com o caráter de objetividade que requer a lei.

Por exemplo, para saber se uma promessa mentirosa pode ser conforme ao dever basta que o homem pergunte a si mesmo: posso eu querer que a mentira tomada como máxima de minha ação se constitua como lei universal? Logo o homem reconhecerá que pode ele desejar subjetivamente a mentira, mas não pode querer uma lei universal da mentira, pois, segundo uma tal lei, todos poderiam mentir, não havendo nem mesmo a possibilidade de firmar qualquer tipo de contrato fundado na promessa; notar-seia então que uma máxima desse tipo tornada lei universal destruir-se-ia a si mesma.

17 "To judge our own actions by the same universal standard which we apply to the action of others is an essential condition of morality." 
Desse modo, fica estabelecida a característica principal de uma lei: a universalidade, ao passo que a máxima se caracterizaria pela contingência. E se uma lei tem por essência a universalidade, então, tem de poder valer para todos os casos sem admitir exceções.

Uma lei da natureza, por exemplo, tem de valer para todos os eventos no tempo, sem exceção, pois se o princípio que todo efeito possui uma causa for uma lei da natureza, fica estabelecida de antemão a impossibilidade de poder haver um efeito sem uma causa no mundo. Caso um evento ocorresse no mundo sem uma causa, ficaria provado que tal regra não pode se constituir em uma lei da natureza, por conta de ela não abarcar todos os casos singulares.

No âmbito da conduta humana, a lei prática tem de valer para o julgamento de todas as ações de qualquer ente racional, pois a moralidade depende que a forma de uma lei universal determine a vontade na produção de uma ação à qual possamos atribuir valor moral.

Por conseguinte, nada senão a representação da lei em si mesma, que em verdade só no ser racional se realiza, enquanto é ela, e não o esperado efeito, que determina a vontade, pode constituir o bem excelente a que chamamos moral, o qual se encontra já presente na própria pessoa que age segundo esta lei, mas se não deve esperar somente do efeito da acção. (Kant, 2005, p.32, grifo do autor).

Trilhar o caminho da retidão moral implica escolher a lei como fonte de determinação da vontade, mas para isso é necessária a coerção pela razão dos impulsos sensíveis, pois para que as ações efetuadas por essa vontade possam ter valor moral, têm de ser realizadas exclusivamente por dever. Logo, o dever pode ser definido como a obrigação de todo ente racional de agir conforme a lei moral, isto é, conforme a representação pura e simples da lei, desde que não haja mescla alguma com impulsos empíricos. 
Esta obrigação à qual a vontade humana está submetida se chama mandamento e a fórmula do mandamento imperativo. Como diz Kant (2005, p.48, grifo do autor): "A representação de um princípio objectivo, enquanto obrigante para uma vontade, chama-se um mandamento (da razão), e a fórmula do mandamento chamase Imperativo".

Contudo, é preciso esclarecer que a lei em si mesma não se constitui necessariamente como uma obrigação ou imperativo moral. Nós podemos dizer que a lei moral aparece para nós como um imperativo ou como uma obrigação por conta de nosso caráter de entes finitos e seres sensíveis, cuja vontade racional tem um imperfeito controle sobre as inclinações, mas a lei moral independe de nossa existência. Desse modo, assim como a lei da natureza não tem a característica de obrigar que os eventos ocorram de determinada maneira, mas ela apenas relata como estes eventos ocorrem na natureza, a lei prática, por sua vez, não carrega consigo a obrigatoriedade, porque ela somente afirma como ações de um modo geral deveriam ocorrer dentro dos parâmetros da moralidade.

A lei moral apresenta-se como uma obrigação ao homem em função de sua vontade, afetada por inclinações, não ser imediatamente conforme às exigências da razão, isto é, a máxima na qual o homem funda sua ação pode ser distinta da prescrição da lei. Mas, para o caso de haver uma vontade pura que esteja de acordo com a lei tanto objetiva quanto subjetivamente, a obrigação não faz nenhum sentido. Segundo Paton (1971, p.70, grifo do autor, tradução nossa):

A lei moral aparece para nós sob condições humanas como uma obrigação ou imperativo, porque em nós a razão não domina completamente as inclinações; mas esta característica não pertence à lei moral como tal. Para a vontade de um ser 
perfeito a lei moral é a lei da santidade; para a vontade de todo ente racional finito ela é uma lei do dever. ${ }^{18}$

Nestes termos, parece que a vontade humana somente quando for determinada objetivamente pela lei e subjetivamente pelo respeito a esta lei, poderá ser considerada boa sem reserva. A vontade, no entanto, encontra-se diante de dois princípios distintos de determinação, um subjetivo e outro objetivo, e a conformidade entre eles, ou seja, que o princípio subjetivo possa valer objetivamente, é que pode garantir a produção de uma boa vontade. No entanto, em uma vontade santa o princípio subjetivo já se encontra em conformidade com o princípio objetivo, desse modo não cabe a esta vontade agir sob imperativos.

Uma vontade perfeitamente boa estaria portanto igualmente submetida a leis objectivas (do bem), mas não se poderia representar como obrigada a acções conformes à lei, pois que pela sua constituição subjectiva ela só pode ser determinada pela representação do bem. Por isso os imperativos não valem para a vontade divina nem, em geral, para uma vontade santa; o dever (Sollen) não está aqui no seu lugar, porque o querer coincide já por si necessariamente com a lei. (Kant, 2005, p.49, grifo do autor).

Temos, portanto, de determinar qual espécie de imperativo tem de determinar a vontade para que ela seja considerada boa sem reserva.

18 "The moral law appears to us under human conditions as a command or imperative, because in us reason has not full control over the inclinations; but this characteristic does not belong to the moral law as such. For the will of a perfect being the moral law is a law of holiness; for the will of every finite rational being it is a law of duty." 


\section{Imperativos: categóricos e hipotéticos}

A representação de um princípio objetivo que obriga a vontade a agir chama-se mandamento e sua fórmula, imperativo. Os imperativos exprimem-se pelo verbo dever e mostram a relação existente entre uma lei objetiva e uma vontade subjetivamente determinada; por esta razão, não são válidos para uma vontade absolutamente pura ou para uma vontade santa, isto é, para uma vontade que se identifique totalmente com a lei, mas exprimem a relação entre as leis objetivas e a imperfeição da vontade humana. A boa vontade, portanto, tem de estar submetida a leis objetivas, porque a vontade para ser boa só pode ser determinada pela representação do bem.

Todos os imperativos se exprimem pelo verbo dever (sollen), e mostram assim a relação de uma lei objectiva da razão para uma vontade que segundo a sua constituição subjectiva não é por ela necessariamente determinada (uma obrigação). Eles dizem que seria bom praticar ou deixar de praticar qualquer coisa, mas dizem-no a uma vontade que nem sempre faz qualquer coisa só porque lhe é representado que seria bom fazê-la. (Kant, 2005, p.48).

Quando a vontade não se identifica plenamente com as prescrições da razão, as ações que objetivamente são necessárias são subjetivamente contingentes, e é por isso que a determinação racional da vontade se impõe ao homem como obrigação. Como já foi dito, isto não ocorre com a vontade divina ou com qualquer vontade santa, porque neste caso as ações que delas decorrem são tanto objetiva quanto subjetivamente necessárias. A diferença reside no fato de que o homem possui por um lado a razão, mas por outro, corpo e inclinações, o que caracteriza sua finitude, 
ao passo que a divindade, se é que um ente assim existe, caracteriza-se por ser apenas inteligência.

Segundo Kant, todos os imperativos ordenam ou hipotética ou categoricamente, e como afirma Beck (1958, p.14, tradução nossa), eles expressam a necessidade de uma ação: "O imperativo expressa a obrigatoriedade de uma ação, a necessidade (condicional ou incondicional) da qual é expressa em uma lei natural". ${ }^{19}$

Os imperativos hipotéticos representam a necessidade de uma ação possível como meio para alcançar um determinado objeto do desejo; apresentam a ação como boa tendo em vista um fim possível ou real. Se é possível, o imperativo é problemático; se é real, é assertórico-prático. Os imperativos categóricos são os que representam uma ação como objetivamente necessária por si mesma. Se os hipotéticos visam a um fim determinado para a ação, o fim visado pelos categóricos reside na própria ação, e, por isso, ela é boa em si mesma e por si mesma.

Como afirma Beck (1957, p.8, tradução nossa), Kant ainda utiliza outros termos para descrever estes imperativos: Na Fundamentação e ocasionalmente na segunda Crítica, termos de modalidade são usados para distinguir entre os mais diversos imperativos. O imperativo técnico é chamado problemático, o pragmático é chamado assertórico, e o categórico é chamado apodítico", ${ }^{20}$

Os imperativos hipotéticos problemáticos impõem como obrigação à vontade de um ente racional regras de

19 "The imperative express the necessitation of an action, the necessity (either conditional or unconditional) of which is expressed in a natural law."

20 "In the Groundwork and occasionally in the second Critique, terms of modality are used to distinguish among the several imperatives. The technical imperative is called problematic, the pragmatic is called assertoric, and the categorical is called apodictic." 
destreza que determinam uma ação em vista de um fim possível, e poderiam ainda se chamar de imperativos técnicos pertencentes à arte. Kant (2005, p.51, grifo do autor) dá um exemplo no caso da arte de educar. Diz ele:

Como não sabemos na primeira juventude quais os fins que se nos depararão na vida, os pais procuram sobretudo mandar ensinar aos filhos muitas coisas e tratam de lhes transmitir a destreza no uso dos meios para toda sorte de fins, de nenhum dos quais podem saber se de futuro se transformará realmente numa intenção do seu educando, sendo entretanto possível que venha a ter qualquer deles.

Mas há uma finalidade que todos os seres racionais perseguem; trata-se de uma necessidade natural que o homem tem de ser feliz. Neste caso, todo o imperativo que se relacione com a escolha dos meios para atingir a felicidade é assertórico, mas poderia ainda chamar-se de conselhos da prudência.

A semelhança entre os imperativos problemáticos e assertóricos está no fato de que ambos ordenam hipoteticamente, isto é, a ação não é ordenada absolutamente, mas como meio para um fim. Mas são diferentes, porque o assertórico não deve propor uma ação somente como necessária para uma intenção incerta, simplesmente possível como ocorre com um imperativo problemático, mas para uma intenção que se pode admitir como certa e a priori para toda gente.

Beck (1957, p.9, tradução nossa) sintetiza a noção de imperativo hipotético do seguinte modo:

Um imperativo hipotético (problemático ou assertórico) é aquele que vale para qualquer ente racional sob a condição que este ente tenha um certo fim ou propósito no qual se acredita ser o efeito da ação da qual se diz ser executada por ele, e 
na qual declara esta condição como a condição restritiva sob a validade do imperativo. ${ }^{21}$

O imperativo categórico não se relaciona com a matéria da ação, isto é, com seu conteúdo, mas com a forma, com o princípio que fundamenta a vontade, e, por isso, este imperativo também pode ser denominado de o verdadeiro mandamento da moralidade.

Em resumo, temos o seguinte quadro: ${ }^{22}$

\begin{tabular}{c|c|c}
\hline \multicolumn{3}{c}{ Imperativos } \\
\hline Categórico & \multicolumn{2}{c}{ Hipotéticos } \\
\hline \multirow{2}{*}{$\begin{array}{c}\text { Mandamento } \\
\text { da moralidade }\end{array}$} & Problemáticos & Assertóricos \\
\cline { 2 - 3 } & Regras de destreza & Conselhos de prudência \\
\hline Imperativo moral & Imperativos técnicos & Imperativos pragmáticos \\
\hline Pertencente & $\begin{array}{c}\text { Pertencentes à arte } \\
\text { e às ciências }\end{array}$ & $\begin{array}{c}\text { Pertencentes ao bem-estar } \\
\text { e à felicidade }\end{array}$ \\
\hline
\end{tabular}

Os princípios apresentados acima se distinguem pelo modo pelo qual se relacionam com a vontade no tocante à forma da obrigação. Somente o mandamento da moralidade pode obrigar de modo incondicionado, ao passo que uma regra ou um conselho tem uma necessidade apenas contingente e subjetiva.

Pois só a lei traz consigo o conceito de uma necessidade incondicionada, objectiva e consequentemente de validade geral, e mandamentos são leis a que tem de se obedecer, quer dizer que se têm de seguir mesmo contra a inclinação. O con-

21 "A hypothetical (problematic or assertoric) imperative is one which holds for any rational being under the condition that this being has a certain end or purpose which is believed to be the effect of the action he is told to execute, and which states this condition as the restrictive condition on the validity of the imperative."

22 Cf. Kant, 2005, p. 53. 
selho contém, na verdade, uma necessidade, mas que só pode valer sob a condição subjectiva e contingente de este ou aquele homem considerar isto ou aquilo como contando para a sua felicidade; enquanto que o imperativo categórico, pelo contrário, não é limitado por nenhuma condição e se pode chamar propriamente um mandamento, absoluta -, posto que praticamente, necessário. (Kant, 2005, p.53, grifo do autor).

Contudo, surge a questão: como são possíveis todos esses imperativos? Tal pergunta exige que se saiba como pode ser pensada a obrigação da vontade que o imperativo exprime na tarefa a cumprir, pois "os imperativos são apenas fórmulas para exprimir a relação entre leis objectivas do querer em geral e a imperfeição subjectiva deste ou daquele ser racional, da vontade humana por exemplo" (Kant, 2005, p.49).

A estratégia de Kant, ao definir os imperativos, visa mostrar o modo como a vontade se vê submetida a uma lei que constitui, para ela, enquanto subjetivamente limitada, uma obrigação. No caso dos imperativos hipotéticos, a obrigação da vontade surge na medida em que ela se coloca um objeto a alcançar, e essa intenção determina a ação que deve permitir atingi-lo. Desse modo, a vontade só se vê como obrigada na medida em que quer alguma coisa e, renunciando a esse querer, desaparece também a obrigação que prescreve uma ação para alcançá-la.

Os imperativos desta espécie fundam-se no silogismo hipotético "se...então", a partir do qual o sujeito agente encontra uma fórmula racional para realizar sua ação que diz: "se queres y, então faça x". Kant chama imperativos desta espécie de hipotéticos, porque fazer x só é racional sob a hipótese de que se queira y. Como diz Tugendhat (1996, p.166):

Se chamamos de $\mathrm{P}$ a pessoa, $\mathrm{x}$ a ação ordenada e y o fim, então resulta: 'P (se ele se deixa determinar exclusivamente 
pela razão) quer necessariamente $\mathrm{x}$, se ele quer y' (dos outros acréscimos aqui necessários, que seja pressuposto não ter $\mathrm{P}$ razões para não querer $\mathrm{x}$, e que seja abstraído ao mesmo tempo de todas as demais intenções de $\mathrm{P}$, podemos abstrair com Kant). Naturalmente, a condição que Kant formula na proposição entre parênteses é obrigatoriamente necessária; isto diferencia exatamente uma ação racional de uma irracional, que a pessoa (abstraindo-se sempre de outras condições suplementares), se ela quer o fim, também quer o meio necessário, se ele se deixa determinar pela razão.

Desse modo, as regras de destreza implicam uma relação de identidade entre os fins e meios, por isso são analíticos, ou seja, por meio de uma análise da ação realizada é possível encontrar o princípio em que esteja seu fundamento. Como afirma Kant (2005, p.54):

Quem quer o fim, quer também (se a razão tem influência decisiva sobre as suas acções) o meio indispensavelmente necessário para o alcançar, que esteja no seu poder [...], pois no querer de um objecto como actividade minha está já pensada a minha causalidade como causalidade de uma força actuante, quer dizer o uso dos meios, e o imperativo extrai o conceito das ações necessárias para este fim do conceito do querer deste fim.

Os conselhos de prudência também são analíticos, pois assim como as regras de destreza, ordenam os meios para aquilo que se pressupõe ser desejado como fim. Se por um lado a intenção de obter felicidade pode ser tida como certa por todo ente finito, por outro, se nos atentarmos para a escolha dos meios a fim de obtê-la, notaremos que as ações para tanto não podem ser ordenadas de maneira absoluta. Daqui se conclui que os conselhos da prudência não podem ordenar de um modo objetivo e necessário e, por isso, não podem ser considerados como mandamentos da razão. 
A possibilidade do imperativo da moralidade não pode estar fundada em nenhum exemplo, porque nada nos garante nos exemplos extraídos da experiência que a vontade seja sempre e só determinada pela lei. A vontade pode ser determinada por outros móbiles, ainda que não pareça. Pode ser o receio da vergonha que nos leva a agir desta ou daquela maneira, quando não fazemos promessas enganadoras, por exemplo. Deste modo, o pretenso imperativo moral, que pareceria categórico e incondicional, revelar-seia uma prescrição que tem por objetivo alertar para as vantagens ou desvantagens de uma determinada ação.

$\mathrm{Na}$ relação da vontade com uma lei incondicionada, o conceito mesmo dessa lei exclui a possibilidade do silogismo hipotético "se... então" que caracteriza os imperativos de modo geral, e a conformidade entre vontade e lei tem de se dar de maneira a excluir da determinação daquela toda a matéria da ação. Em outras palavras, a vontade tem de ser determinada somente pela lei que lhe prescreve uma ação como praticamente necessária. Tugendhat (1996, p.144) diz que "Isto leva Kant a conceber a possibilidade de um imperativo da razão sem uma tal pressuposição. Este teria por conseguinte a forma "é bom fazer $\mathrm{x}=$ é racional fazer x', ponto e sem condição”.

Desse modo, a possibilidade de um imperativo categórico tem de residir a priori na razão, pois somente deste modo ele teria o caráter de uma lei prática, porque, ao contrário do que sucede com os imperativos hipotéticos que, por sua vez, são analíticos, o imperativo da moralidade tem de representar uma proposição sintético-prática a priori.

Kant, no entanto, aborda as dificuldades de fundamentar uma tal proposição, que para tanto precisa que o imperativo categórico tenha o caráter de uma lei, e não simplesmente de um princípio, que será de agora em diante atribuído aos demais tipos de imperativos. Os princípios podem ser empíricos e variar de acordo com a intenção e o 
objeto da vontade, que se veria então na condição de poder determinar, por meio da razão, para cada uma de suas intenções, qual o princípio de ação melhor lhe proporcionaria a consecução de seu objetivo. No caso da lei incondicionada, tal escolha não é possível, porque o imperativo categórico não pode ordenar uma ação com relação a objetos, mas tem de ordenar simplesmente uma ação de modo a priori e, desse modo, apresentar a mesma necessidade que se exige de uma lei. Por isso, Beck (1957, p.13-4, tradução nossa) afirma:

Mas se nós nos recordarmos que um imperativo é somente o modo pelo qual uma lei é formulada para um ser que deve fazer, mas não faz por natureza o que a lei diz que um ser racional deveria fazer, nós podemos bastante facilmente formular a lei à qual o imperativo corresponde, e é esta lei que Kant diz ser sintética. ${ }^{23}$

Para que o imperativo constitua uma proposição sintético-prática a priori, ele tem de estar relacionado de modo totalmente a priori com a vontade de todo ente racional, de forma que a ideia de uma razão capaz de determinar uma vontade de modo subjetivo possa tornar esta ação objetivamente necessária, o que explicaria o fato de o imperativo ordenar categoricamente.

Portanto, em oposição a um imperativo hipotético, que somente nos dá seu conteúdo a partir de determinadas condições que nos são dadas conforme a ação desejada, um imperativo categórico teria de mostrar imediatamente seu conteúdo. Pois este imperativo apenas conteria a lei e a ne-

23 "But if we remember that an imperative is only the mood in which a law is formulated for a being who ought to but does not by nature do what the law says a rational being would do, we can easily enough formulate the law to which the imperative corresponds, and it is this law that Kant means is synthetic." 
cessidade de adequação da máxima à lei. Ora, a lei não contém nenhuma condição que a limite, daí sua universalidade, e somente o imperativo categórico é capaz de representar como necessária a conformidade da máxima à lei.

Como bem recorda Beck (1957, p.14, tradução nossa): “Todas as leis são juízos sintéticos, e se elas são leis em um estrito senso (se são leis da natureza ou da moralidade) elas são, para Kant, a priori”. ${ }^{24}$ Se a lei da moralidade existe de modo a priori, e se o mandamento nada mais é que a lei, podemos concluir que se um tal imperativo categórico de fato existe, sua forma não pode ser outra senão a seguinte: "Age apenas segundo uma máxima tal que possas ao mesmo tempo querer que ela se torne lei universal" (Kant, 2005, p.59, grifo do autor).

Se no mais lato sentido chamamos natureza os efeitos produzidos pela universalidade da lei, isto é, a realidade que é determinada por leis universais, o imperativo categórico, como imperativo do dever, pode ainda se exprimir do seguinte modo (segunda fórmula do imperativo categórico, a fórmula da lei da natureza): "age como se a máxima de tua acção se devesse tornar, pela tua vontade, em lei universal da natureza" (idem, grifo do autor).

Ao pensarmos em agir sob um imperativo hipotético em geral, seria impossível obtermos de antemão o conteúdo deste imperativo, isto é, que ele nos diga como devemos agir, pois isso só acontece quando a condição nos é dada. Com efeito, ao pensarmos no imperativo categórico como princípio determinante da ação, sabemos de modo a priori o que ele determina como dever a uma vontade subjetivamente contingente, pois o mandamento se constitui como independente de qualquer condição sensível. O imperati-

24 "All laws are synthetic judgments, and if they are laws in a strict sense (whether laws of nature or laws of morality) they are, for Kant, a priori". 
vo categórico, forma que assume a lei moral, é uma imposição do sujeito numênico a sua dimensão fenomênica e, por isso, tem de ser o único imperativo da moralidade.

Desse modo afirma Kant (2005, p.58-9, grifo do autor):

Quando penso um imperativo hipotético em geral, não sei de antemão o que ele poderá conter. Só o saberei quando a condição me seja dada. Mas se pensar um imperativo categórico, então sei imediatamente o que é que ele contém. Porque, não contendo o imperativo, além da lei, senão a necessidade da máxima que manda conformar-se com essa lei, e não contendo a lei nenhuma condição que a limite, nada mais resta senão a universalidade de uma lei em geral à qual a máxima da ação deve ser conforme, conformidade essa que só o imperativo nos representa propriamente como necessária.

Por esta razão até mesmo o homem de entendimento comum tem diante de si uma bússola para guiar suas ações, pois basta perguntar a si mesmo se é possível querer que a máxima determinante de sua ação possa ser elevada à lei da natureza. Segundo Tugendhat (1996, p.148):

Kant diz com razão que eu teria de poder querer que a máxima, de acordo com a qual eu ajo, se torne lei universal. Claro está naturalmente que o querer de que se trata aqui é o querer plenamente comum ainda pré-moral, egoísta, pois o querer somente é moral na medida em que se deixa determinar pelo imperativo categórico.

\section{Exemplifiquemos:}

A máxima de pedir dinheiro emprestado prometendo pagá-lo, sabendo, todavia, que tal fato nunca sucederá, pode transformar-se em lei universal da natureza? Ora, a universalidade de uma lei que permitisse a cada homem prometer o que não pode cumprir tornaria impossível a promessa, pois ninguém nunca acreditaria em promessas. Logo, esta 
máxima não pode transformar-se em lei universal. Como afirma Beck (1957, p.14-5, tradução nossa): "Isto quer dizer que o imperativo categórico obriga que a máxima em si mesma tenha a forma de uma lei universal e necessária. Somente esta forma deve determinar o teor da máxima". ${ }^{25}$

O problema, porém, não se resume apenas em estabelecer qual seja a forma de um imperativo categórico, mas há que provar que este imperativo a priori existe, que constitui uma lei prática, que ordena independentemente de todo o móbil e que a obediência a esta lei constitui o dever. No entanto, a pergunta de como é possível um imperativo categórico fica de fato irrespondida na Fundamentação, pois isto implica uma crítica da faculdade de desejar, o que Kant realizará na Crítica da razão prática delegando a um factum da razão pura prática o fundamento do princípio objetivo da moralidade. ${ }^{26}$ Vale lembrar, porém, que nosso objetivo não é o de fundamentar o imperativo categórico, mas trata-se de investigar como o mesmo pode se tornar um motivo determinante de nossa vontade face às inclinações sensíveis.

Contudo, uma coisa é certa, a realidade de um princípio objetivo não pode derivar da constituição particular da natureza humana dado que o dever é a necessidade prática incondicionada da ação e é válido para todos os seres racionais e, por isso, mesmo se pudéssemos derivar tal imperativo de condições sensíveis ele deixaria de ser categórico para ser hipotético. Não obstante, para escapar à relação entre fins e meios que caracteriza os imperativos hipotéticos, Kant (2005, p.68-9, grifo do autor) formula uma suposição acerca de um fim em si como base para o imperativo categórico:

25 "That is to say, the categorical imperative commands that the maxim itself have the form of universal and necessary law. This form alone must determine the content of the maxim."

26 Cf. Kant, 2003, p.107. 
Admitindo porém que haja alguma coisa cuja existência em si mesma tenha um valor absoluto e que, como fim em si mesmo, possa ser a base de leis determinadas, nessa coisa e só nela é que estará a base de um possível imperativo categórico, quer dizer, de uma lei prática.

Kant (idem, p.69), por sua vez, conclui:

O fundamento deste princípio é: A natureza racional existe como fim em si. É assim que o homem se representa necessariamente a sua própria existência; e, neste sentido, este princípio é um princípio subjectivo das ações humanas. Mas é também assim que qualquer outro ser racional se representa a sua existência, em virtude exactamente do mesmo princípio racional que é válido também para mim; é portanto simultaneamente um princípio objectivo, do qual como princípio prático supremo se têm de poder derivar todas as leis da vontade.

Se as máximas se devem ajustar às leis universais, se essa lei existe, então ela tem de estar ligada a priori ao conceito de vontade de um ser racional em geral. Ora, se deve haver um princípio prático supremo e um imperativo categórico no que respeita à vontade humana, então tem de ser tal que, da representação daquilo que é necessariamente um fim para toda a gente, porque é fim em si mesmo, faça um princípio objetivo, da vontade, que possa, por conseguinte, servir de lei prática universal.

Kant pressupõe que, sem nenhuma referência a fins, não pode haver nenhuma determinação da vontade no homem. Mas, no caso de a vontade ser determinada pelo imperativo categórico, a vontade não pode se relacionar com a matéria da ação, ou seja, com um fim material qualquer a ser alcançado, mas somente com um fim em si mesmo, isto é, incondicional, que se atribui a ação em si mesma, pois esta é a obrigação que se coloca para toda vontade subjetivamente limitada. 
Os princípios práticos ou éticos são formais quando se abstrai de todos os fins subjetivos e materiais se estes lhes servirem de fundamento. Todos os princípios materiais que se relacionam com a faculdade de desejar do sujeito têm um valor relativo e não universal porque estabelecem fins que são a base dos imperativos hipotéticos.

No entanto, o fundamento de um imperativo categórico está naquilo que, por si mesmo, tem um valor absoluto e constitui um fim em si mesmo. Todo homem, porque é pessoa, existe como fim em si mesmo; daí que deva ser considerado sempre como fim e nunca como meio e isto é que distingue o homem dos seres irracionais e das coisas que têm um valor relativo e, por isso, podem ser utilizados como meios.

Da natureza racional deduz Kant (2005, p.69, grifo do autor) o imperativo categórico, ou seja, se existe um ser que é fim em si mesmo, tem de haver um princípio que demonstre esta finalidade. Segue-se daqui a terceira fórmula do imperativo categórico (a fórmula do autofim): "Age de tal maneira que uses a humanidade, tanto, na tua pessoa como na pessoa de qualquer outro, sempre e simultaneamente como fim e nunca simplesmente como meio".

Face a esta formulação do imperativo, verifiquemos como se adequa a ela o exemplo dado anteriormente da falsa promessa: ora, o homem que pretender agir sob a máxima de pedir dinheiro emprestado prometendo pagá-lo, sabendo, todavia, que tal fato nunca sucederá, logo reconhecerá que está usando outro homem simplesmente como meio e não como um fim em si mesmo e estaria, desse modo, ferindo o princípio de humanidade. Desse modo, diz Tugendhat (1996, p.155): “o imperativo categórico vai desembocar no mandamento: não instrumentalizes ninguém! Pode-se também verter isto positivamente, dizendo: respeita-o como sujeito de direito! Ou com Kant podese dizer: respeita-o em sua 'dignidade'!". 
Fica, portanto, estabelecida a distinção entre os princípios determinantes da vontade, a partir da qual se mostram evidentes as razões pelas quais somente o imperativo categórico pode determinar a vontade com vistas à realização de ações com conteúdo moral. Com efeito, segue-se agora a seguinte pergunta: como pode este imperativo tornar-se um motivo suficientemente determinante da vontade? 


\section{3 \\ DOS MOTIVOS DETERMINANTES DA VONTADE}

Dado o percurso investigativo traçado até aqui (cujo início deu-se pela análise da noção de boa vontade como o padrão de juízo moral provindo do entendimento vulgar, passando pelo exame da natureza humana, do qual pudemos identificar os princípios sob os quais a vontade pode ser determinada), descobrimos que somente o princípio puro da razão prática, ou seja, o imperativo categórico pode produzir uma boa vontade com vistas à realização de uma ação com conteúdo moral.

No entanto, concorrente ao princípio puro da razão estão os princípios práticos empíricos provindos da sensibilidade, que acabam por deixar, desse modo, a vontade diante de uma encruzilhada. Da ambivalência existente na natureza humana surge, então, um conflito aparentemente insolúvel entre razão e sensibilidade na determinação da vontade, visto que a ambivalência somente é extinta com a morte do sujeito. Disso segue o seguinte problema: o que pode motivar o homem a agir conforme o imperativo moral diante das solicitações do desejo sensível?

Se já constatamos que somente o princípio puro da razão pode determinar uma vontade como boa, cabe agora 
perguntarmos pelo fundamento da escolha, ou seja, pelo motivo determinante da vontade, no sentido de procurar desvendar o que pode motivar o homem a agir moralmente face às inclinações sensíveis.

O presente capítulo pretende, portanto, primeiramente explicar por que o homem carece de um motivo para agir moralmente, mesmo tendo o conhecimento de que somente uma vontade boa determinada pelo imperativo categórico é que pode promover boas ações, e apontar, em seguida, os possíveis elementos motivacionais do homem na escolha pelo princípio puro como fonte de determinação da vontade.

\section{A distinção entre o móbil e o motivo da razão prática}

O problema da motivação moral possui importância central na ética kantiana, pois ao perguntar pelo motivo estamos perguntando pelo fundamento racional que, em última instância, move a ação. Trata-se, pois, de procurar pelo que está por trás das escolhas humanas, isto é, aquilo que está para além do que é empiricamente observado. Mas a pergunta preliminar que se coloca aqui é a seguinte: por que o homem carece de um motivo para a escolha?

A vontade do homem carece de um motivo para a escolha pelo fato de sua natureza estar cindida entre razão e sensibilidade. Se não houvesse um motivo, a máxima da ação estaria fundada na indiferença, segundo a qual tanto a lei quanto a inclinação teriam o mesmo peso na balança, e a decisão por uma ou por outra ocorreria sem uma razão suficiente, ou seja, tanto o princípio puro quanto o princípio empírico se apresentariam indiscerníveis ao homem, possuindo o mesmo valor. Mas se a natureza racional do homem fosse a fonte exclusiva de determinação imediata da 
vontade, desapareceria a exigência de um motivo para a adoção de máximas. Sucederia também do mesmo modo, se a natureza sensível exercesse o papel de fundamento suficiente de determinação da vontade.

Todavia, pelo fato de o homem possuir um caráter inteligível e outro empírico, sua condição deixa o arbítrio em uma encruzilhada, na qual ele tem de decidir entre a lei moral e o desejo sensível na determinação da vontade e, para tanto, ele carece de um motivo para escolher entre um e outro. A divindade, por possuir apenas um caráter inteligível, age moralmente. Como afirma Reath (1989, p.286, nota de rodapé, tradução nossa):

A explicação do por que a conduta humana é caracterizada por incentivos deve ser a de que, em nós, razão e sensibilidade originam diferentes fontes para a escolha [...]. Visto uma vontade divina atuar somente por motivos válidos objetivamente, não há variação no caráter de suas escolhas, e, desse modo, não há sentido para falar sobre uma espécie de motivação a partir da qual ela atuasse. ${ }^{1}$

Na ética kantiana, por sua vez, somente às ações realizadas por dever pode ser atribuído valor incondicional e, por conseguinte, podem ser consideradas válidas moralmente, ao passo que as ações resultantes de outros princípios quando muito podem conter legalidade, mas não moralidade, por estarem ligadas à satisfação particular das inclinações de determinado sujeito que visa neste caso sua própria felicidade.

1 "The explanation as to why human conduct is characterized by incentives must be that, in us, reason and sensibility provide different grounds for choice [...]. Since a divine will acts only for objectively valid motives, there is no variation in the character of its choices, and thus no sense to talking about the kind of motivation from which it acts." 
Cabe, então, a Kant, explicar qual é o motivo capaz de determinar a vontade com vistas à realização de ações morais. Para tanto, faz-se necessário traçar a diferença entre os tipos de motivação, isto é, proporcionar a distinção entre a motivação sensível e a motivação racional, tendo ainda de mostrar como elas se relacionam e determinam a vontade.

Na introdução da Fundamentação, Kant adverte para o fato de que Wolff, cujo trabalho realizado no âmbito da Filosofia Moral foi intitulado de Filosofia prática universal, bem como os defensores desta filosofia cometem um equívoco que acaba por comprometê-la. Tais moralistas, segundo Kant (2005, p.18), "não distinguem os motivos de determinação que, como tais, se apresentam totalmente $a$ priori só pela razão e são propriamente morais, dos motivos empíricos, que o entendimento eleva a conceitos universais, só por confronto das experiências".

Kant, por sua vez, ao efetuar a distinção entre os motivos puros dos motivos empíricos, estabelece ainda conceitos distintos para diferenciar uma motivação subjetiva de uma motivação objetiva da faculdade de desejar. Na Fundamentação, temos de considerar as seguintes denominações: "O princípio subjectivo do desejar é o móbil(Triebfeder), o princípio objectivo do querer é o motivo (Bewegungsgrund); daqui a diferença entre fins subjectivos, que assentam em móbiles, e objectivos, que dependem de motivos, válidos para todo ser racional" (idem, p.67).

$\mathrm{Na}$ Crítica da razão prática, Kant utilizará apenas o termo Triebfeder, que ele define como o fundamento determinante subjetivo da vontade de um ente cuja razão não é, já por natureza, necessariamente conforme à lei objetiva. ${ }^{2}$ Essa atitude de Kant, no entanto, causa certa controvérsia

2 Cf. Kant, 2003, p.249. 
já que, na Fundamentação, o mesmo termo tem outra conotação.

O problema de uma definição precisa do termo tornase ainda maior se considerarmos que até mesmo na Fundamentação, na qual Kant procurou estabelecer certa distinção entre móbil e motivo, há passagens ${ }^{3}$ em que ele parece utilizar o termo móbil em sentido moral. Como diz Rohden em uma nota de rodapé da segunda Crítica, neste momento "Triebfeder passa, pois, a identificar-se com Bewegungsgrund, tomando ambos o sentido de um fundamento determinante subjetivo da ação" (Kant, 2003, p.584).

O mais importante, contudo, é observar que Kant estabelece uma nova concepção de motivação moral, baseada na distinção entre móbiles subjetivos e motivo objetivo. Móbiles representam fundamentos subjetivos do desejo, portanto, supõem fins que nos serão dados por meio de nossa natureza sensível (desejos, inclinações, paixões). Com o termo motivo, Kant, ao contrário, foca a natureza racional como legislativa: a base motora representa, no reconhecimento do valor absoluto do ser racional, um motivo que tem de ser válido universalmente, porque a natureza é idêntica em todo ser racional. Em outras palavras, um motivo é um querer nosso fundado na razão, um móbil é um motivo externo do querer fundado na sensibilidade. Se do ponto de vista motivacional a razão tem de ser mesmo prática, ela terá então de representar um fundamento objetivo do querer, ou seja, um motivo capaz de determinar a vontade.

Este fundamento objetivo que requer a razão para que ela se torne efetivamente prática, dá-se, segundo Kant, a partir da distinção entre fim e meio. Kant advoga em favor da tese de que somente a razão pode oferecer um motivo

3 Cf. idem, 2005, p.115. 
porque é a única capaz de originar um fim válido para todo ente racional, ao passo que todos os móbiles não passam de meros meios que o sujeito propõe a si com vistas a atingir um fim exclusivamente particular.

Ora aquilo que serve à vontade de princípio objectivo da sua autodeterminação é o fim ( $Z$ weck), e este, se é dado pela só razão, tem de ser válido igualmente para todos os seres racionais. O que pelo contrário contém apenas o princípio da possibilidade da acção, cujo efeito é um fim, chama-se meio. [...] Os fins que um ser racional se propõe a seu grado como efeitos da sua acção (fins materiais) são na totalidade apenas relativos; pois o que lhes dá o seu valor é somente a sua relação com uma faculdade de desejar do sujeito com características especiais, valor esse que por isso não pode fornecer princípios universais para todos os seres racionais, que sejam também válidos e necessários para todo o querer, isto é leis práticas. Todos estes fins relativos são, por conseguinte, apenas a base de imperativos hipotéticos. (Kant, 2005, p.67, grifo do autor).

Esta perspectiva, no entanto, compreende o homem em sua parte intelectual que faz uso da razão ao determinar a si mesmo um fim a que se pretende realizar. Disso se segue a seguinte questão: se o homem, considerado em sua parte sensível, está preocupado primeiramente com seu bemestar e felicidade próprios, como pode a lei servir de motivo determinante da vontade? Diante deste contexto, como pode a razão representar um fundamento objetivo ao querer humano, a partir do qual pudesse originar-se um fim válido universalmente? Pois, como afirma Tugendhat (1996, p.165):

A pergunta não é como o imperativo poderia ser pensado como mandamento, mas como ele poderia ser entendido para que se torne decisivo para a vontade. De acordo com Kant esta 
questão não causa dificuldade no caso de imperativos hipotéticos. Pois quem quer o fim quer também o meio.

Porque os homens, além de seres racionais, são também seres sensíveis, não basta a eles a razão como motivo, já que o fim objetivo pode não coincidir com o fim subjetivo, isto é, com o móbil. Os homens podem preterir uma ação, a ser realizada conforme a lei, por outra que seja para satisfazer suas inclinações, mesmo que tenham compreendido a inferioridade moral de seu querer e fazer, pois, como ser racional, o homem tem a liberdade tanto para o bem quanto para o mal. Mas este será um assunto para o próximo capítulo.

Diante dos fatos, eis aqui a chave da explicação que mais se apresenta de modo satisfatório segundo nossa investigação: o conceito do dever. O dever obriga o homem a adequar sua máxima a uma legislação universal e, desse modo, ordena que os móbiles subjetivos possam valer como motivo objetivo para que sejam válidos moralmente. Pois se o dever não fosse capaz de determinar a vontade na produção de uma ação válida moralmente, então este conceito não passaria de mera quimera, no entanto, "com isto [com o conceito do dever] está perfeitamente de acordo a comum razão humana nos seus juízos práticos e tem sempre diante dos olhos este princípio" (Kant, 2005, p.33).

O autêntico valor moral das ações está intimamente atrelado ao motivo determinante da vontade, "e, uma vez que ela tem de ser determinada por qualquer coisa, terá de ser determinada pelo princípio formal do querer em geral quando a acção seja praticada por dever, pois lhe foi tirado todo o princípio material" (idem, p.30, grifo nosso). Notarse-á, porém, que está descartada a possibilidade de haver indeterminação da vontade, pois para que ações sejam efetivadas no mundo a vontade tem de ser determinada pelo princípio formal da razão ou pelas inclinações sensíveis. Mas o valor moral ou incondicionado tem de ser atribuído 
a uma ação cuja realização foi desprovida de motivação empírica, na qual a vontade foi exclusivamente determinada pelo princípio formal do querer. Como Tugendhat (1996, p.120) afirma:

Muitos diriam: tão só quando ajudamos alguém por inclinação e isto quer dizer, como diz Kant, por 'simpatia' ou compaixão, podemos dizer que nós o ajudamos, enquanto Kant defende a opinião contrária de que nossa ajuda somente então é moral, quando ocorre apenas por dever e não por inclinação, ou, formulado de forma menos crassa, quando a inclinação pelo menos não exerce influência sobre nossa motivação.

Embora a ética kantiana considere somente a ação efetuada por dever como a única instituída de conteúdo moral, esta exigência, diante das disposições originárias da natureza humana, encontra fortes obstáculos para fazer com que a lei moral prevaleça em detrimento das inclinações. Segundo Allison (1995, p.108, grifo do autor, tradução nossa),

A principal contribuição de Kant sobre o valor moral e, de fato, para a sua psicologia moral como um todo, é esse contraste entre dever e inclinação, como duas fontes competitivas da motivação. Apesar de Kant fazer a distinção entre inclinação e medo, a afirmação operativa é a de que toda ação é motivada, ou pela inclinação, ou pelo pensamento de dever, isto é, cada ação é aus Neigung ou aus Pflicht. ${ }^{4}$

4 "Central to Kant's account of moral worth and, indeed, to his moral psychology as a whole, is the contrast between duty and inclination as two competing sources of motivation. Although Kant twice distinguishes between inclination and fear, the operative assumption is that every action is motivated by either inclination or the thought of duty, that is, every action is either aus Neigung or aus Pflicht." 
Tratemos, pois, de esclarecer este contraste instituído por Kant entre dever e inclinação como fontes distintas de determinação da vontade.

\section{Motivação sensível e motivação racional}

Kant, em passagem da Fundamentação, afirma que a presença de sentimentos na determinação da vontade ou até mesmo das inclinações na realização de ações humanas são muito favoráveis para a formação de uma vontade boa. ${ }^{5}$ Contudo, Kant adverte para o fato de que, em nenhuma circunstância, podem esses mesmos sentimentos originar uma vontade absolutamente boa, tampouco promover uma ação com conteúdo moral.

Os sentimentos e as inclinações podem até fomentar a prática de ações que estejam em conformidade com o dever, que é o caso de ações realizadas por inclinação imediata, mas este tipo de ação contém apenas legalidade e não moralidade, pois valor moral só pode ser atribuído às ações realizadas exclusivamente por dever.

Como afirma Kant (2005, p.28, grifo do autor):

Ser caritativo quando se pode sê-lo é um dever, e há além disso muitas almas de disposição tão compassiva que, mesmo sem nenhum outro motivo de vaidade ou interesse, acham íntimo prazer em espalhar alegria à sua volta e se podem alegrar com o contentamento dos outros, enquanto este é obra sua.

Eu afirmo porém, que neste caso uma tal acção, por conforme ao dever, por amável que ela seja, não tem contudo nenhum verdadeiro valor moral, mas vai emparelhar com outras inclinações, por exemplo o amor das honras que, quando por feliz acaso topa aquilo que efectivamente é de interes-

5 Cf. Kant, 2005, p.22. 
se geral e conforme ao dever, é consequentemente honroso e merece louvor e estímulo, mas não estima; pois à sua máxima falta o conteúdo moral que manda que tais acções se pratiquem, não por inclinação, mas por dever.

Segundo Paton (1971, p.54, tradução nossa), da argumentação kantiana podemos concluir que é possível existir uma boa ação sem bondade moral: "Se nós julgamos a bondade de uma ação, como Kant faz, pela bondade da vontade manifestada na ação, não é insensato dizer que mesmo uma ação generosa pode existir sem bondade moral, mesmo tendo ela um certo valor em si mesma". ${ }^{6}$ Contudo, neste caso o valor é apenas relativo, porque por mais que estas ações possam ser louváveis, elas estão desprovidas de moralidade pelo fato de a vontade ter sido motivada por uma inclinação sensível e não pela motivação do estrito dever. Paton (idem, p.53-4, tradução nossa) afirma que:

Elas são de algum modo como ações originadas do desejo de honra, um desejo que, embora esteja em um nível inferior, pode também nos levar a agir de acordo com a virtude e que se pode dizer ter sobre si um 'lampejo' de virtude. Ainda sobre um nível inferior, talvez - embora Kant não diga desse modo - elas sejam como ações que se originam da qualidade da coragem animal, que, embora extremamente ajude um homem a ser valente, é ainda uma forma distinta da autêntica virtude de coragem. ${ }^{7}$

6 "If we are to judge the goodness of an action, as Kant does, by the goodness of the will manifested in the action, it is not unreasonable to say that even a generous action may be without moral goodness, though it has a certain value of its own."

7 "They are in some ways like actions spring from desire for honour, a desire which, although it is on a lower level, may also lead us to acts which accord with virtue and may itself be said to have about it a 'glimmer' of virtue. On a still lower level perhaps - though Kant does not say so - they are like acts which spring from the enviable 
Estas pessoas podem realizar uma ação em conformidade com o dever porque em determinada situação a inclinação está de acordo com a lei, mas é preciso observar que, em outro momento, poder-se-ia uma dada inclinação não se conformar a ela, promovendo desse modo uma ação contrária ao dever. Segundo Allison (1995, p.107-8, tradução nossa):

A afirmação central é a de que o valor moral é atribuído a ações, se e somente se elas se fundem no dever (aus Pflicht). Visto que por uma 'boa vontade' (novamente sob condições humanas), Kant obviamente entende ser aquela que é, de algum modo, motivada pelo dever, isso sugere que sua visão é a de que nós podemos dizer que possuímos uma boa vontade apenas nos casos em que nós agimos exclusivamente pelo dever, ou do mesmo modo, apenas nos casos em que nossas ações possuam valor moral. ${ }^{8}$

Desse modo, a cultura do uso dos princípios da razão no momento de decidir o que fazer ou deixar de fazer é indispensável para a intenção de agir moralmente. Pois mesmo tendo a natureza originariamente fornecido à vontade do homem a razão como sua governante, este fato não garante necessariamente que ele agirá exclusivamente em conformidade com princípios puros de determinação. $\mathrm{O}$ oposto sempre é possível, ou seja, o arbítrio pode determinar a vontade de modo patológico por meio de princípios mate-

quality of animal courage, which, though it greatly helps a man to be brave, is still distinct form the genuine virtue of courage."

8 "The central claim is that moral worth is to attributed to actions if and only if they are from duty (aus Pflicht). Since by a 'good will' (again under human conditions) Kant obviously means one that is in some sense motivated by duty, this suggests that his view is that we can be said to have a good will just in case we act from duty alone or, equivalently, just in case our actions posses moral worth." 
riais, pois, no caso de um ente racional, o arbítrio é livre (arbitrium liberum).

Sendo o arbítrio livre, e se é ele quem determina a vontade, então ela pode vir a se tornar tanto boa quanto má. A escolha pelo motivo determinante da vontade é subjetiva, isto é, está conforme ao arbítrio de cada sujeito, sendo a constituição particular da subjetividade o que se pode denominar de caráter. $\mathrm{O}$ caráter constitui-se como a firme disposição do sujeito de querer sempre realizar as ações de uma determinada maneira. Como afirma Allison (1995, p.116, tradução nossa):

A bondade de uma boa vontade é em si mesma uma função de seu caráter, que é a permanente estrutura de seus motivos, ou, em outros termos, de sua disposição (Gesinnung) para atuar com base em máximas moralmente apropriadas. Em outras palavras, uma boa vontade pode ser caracterizada como algo, cuja máxima permanente é a de conformar-se aos ditames da lei moral. ${ }^{9}$

A formação de uma boa vontade passa pela formação do caráter, e se o caráter do sujeito não for bom, isto é, se o sujeito não cultua o uso dos princípios da razão por preferir seguir aos impulsos da sensibilidade, a vontade não será incondicionalmente boa e, consequentemente, podemos concluir que se o caráter não for bom, dele não decorrerá uma boa ação.

É preciso lembrar que é impossível extinguir o desejo sensível, porque a natureza humana, além da razão, possui um corpo, fonte de todas as inclinações. Desse modo, o

9 "The goodness of a good will is itself a function of its character, that is, the permanent structure of its motives or, equivalently, its disposition (Gesinnung) to act on the basis of morally appropriate maxims. Put simply, a good will can be characterized as one whose enduring maxim is to conform to the dictates of the moral law." 
conflito na disputa pela determinação da vontade ainda permanece, existindo, de um lado, a natureza sensível da qual se originam as inclinações, e de outro, a natureza inteligível, fonte do princípio racional puro. $\mathrm{O}$ mais importante, no entanto, é compreender como as inclinações e o dever se relacionam no processo motivacional da vontade.

Por conta dos desejos possuírem como principal característica a insaciabilidade, eles exercem de certo modo um poder despótico sobre a vontade, e o homem tem de coibir essa tirania exercendo uma forte coerção sobre estes desejos. Enquanto o sujeito estiver preso às exigências da sensibilidade, ele será sempre motivado por uma causa determinante exterior, tornando-se um ente totalmente passivo diante de impulsos empíricos. A atividade do sujeito demonstrar-se-á quando o imperativo categórico se fizer motivo para a escolha do fundamento de determinação da vontade.

Ora, é sob o conceito de felicidade que se resume o desejo de satisfação de todas as inclinações e, como o próprio Kant afirma, ser feliz é a aspiração de todo ente racional. Se satisfazer as inclinações dispensa muito esforço, pois, para tanto, basta que a vontade se deixe conduzir passivamente pelo desejo sensível, como seria possível a moralidade sobressair a esta situação exigindo do sujeito a coerção destas inclinações e a submissão completa a uma lei originada a priori na razão? Poderia ainda alguém objetar, por que a felicidade não pode ser o fundamento da moral?

Tendo em vista a cisão do homem entre razão e sensibilidade, a felicidade constitui um fundamento inevitável da faculdade de desejar e, como afirma Kant (2005, p.29, grifo do autor), constitui-se até mesmo como um dever:

Assegurar cada qual a sua própria felicidade é um dever (pelo menos indirectamente); pois a ausência de contentamento com o seu próprio estado num torvelinho de muitos 
cuidados e no meio de necessidades insatisfeitas poderia facilmente tornar-se numa grande tentação para a transgressão dos deveres.

Todavia, a felicidade não pode ser posta como fundamento objetivo da determinação da vontade, porque o que causa prazer para um sujeito pode não causar a outro e, para que uma regra prática se torne lei objetiva, ela tem de conter, em todos os casos e para todos os entes racionais, exatamente o mesmo fundamento determinante da vontade. "Ou seja, aquilo em que cada um costuma colocar sua felicidade tem a ver com o seu sentimento particular de prazer e desprazer e, até, em um e mesmo sujeito, com a carência diversa de mudanças desse sentimento” (Kant, 2003, p.87).

E se para a resolução da questão da felicidade como fundamento determinante da vontade supuséssemos ser possível a todos os entes racionais ter o mesmo sentimento de prazer? Mesmo assim a felicidade seria insuficiente como regra prática universal, pois ainda seria contingente, visto que o sentimento de prazer é físico e só pode ser extraído da experiência sensível, que, por sua vez, não nos dá o princípio da necessidade. E leis são conhecidas somente de modo a priori, pela razão. Desse modo, uma lei prática tem de levar em conta somente a forma, visto que a matéria é incapaz de fornecer um princípio de conduta moral às escolhas humanas.

É inegável que do modo como nossa natureza de entes sensíveis é constituída, as solicitações das inclinações se impõem como se fossem as primeiras e originais, e se esforçam por determinar de modo patológico a vontade na tentativa de elevar o conjunto de nossas máximas a uma legislação universal. Ora, como para aquilo que não carece de muito esforço somos mais fortemente inclinados a realizar, a sensibilidade parece oferecer motivos mais fortes do que 
a lei como fundamento do arbítrio. Desse modo, Allison (1995, p.108-9) afirma:

Contudo, é claro que até onde Kant assume um dualismo entre inclinação e dever, como fontes da motivação, a 'inclinação' deve ser entendida em um amplo sentido em referência a qualquer estimulo à ação que se origine a partir de nossos sentidos, como opostas a nossa natureza racional. Assim compreendida, a inclinação engloba desejos momentâneos, instintos, medos e as desinclinações (Abneigungen), enfim, tudo que pertence exclusivamente à existência sensível..$^{10}$

Pelo fato de as inclinações englobarem tudo aquilo que envolve nossa existência sensível, parece ser inevitável que tais inclinações influenciem o homem no momento da escolha pela ação a praticar, mesmo naquelas em que ele acredita realizar pelo puro dever. Seguindo este raciocínio, Allison (idem, p.108, tradução nossa) defende a tese de que podem existir ações realizadas por dever que ao mesmo tempo tenham admitido a influência da sensibilidade na determinação da vontade. "Em outras palavras, uma boa vontade é manifestada, mas não exclusivamente, em ações que possuam valor moral". ${ }^{11}$

Allison (idem, p.111, tradução nossa) argumenta a partir de uma distinção entre ações realizadas a partir de inclinações, isto é, que tiveram origem na sensibilidade e serviram de motivo para a vontade, e ações que foram apenas

10 "Nevertheless, it is clear that insofar as Kant assumes a dualism of inclination and duty as the sources of motivation, 'inclination' must be construed in a broad sense to refer to any stimulus to action that stems form our sensuous, as opposed to our rational, nature. So construed, inclination encompasses momentary desires, instincts, passions, fears, and disinclinations (Abneigungen), all of which pertain only to sensuously affected beings."

11 "In the words a good will is manifested, but not exclusively, in actions possessing moral worth." 
influenciadas pelas inclinações, mas que em última instância o dever foi o motivo de determinação da vontade. Este último tipo de ação, mesmo tendo admitida a influência da sensibilidade, teria valor moral por ser fruto de uma boa vontade, ou seja, o motivo determinante da ação teria sido o estrito dever.

De fato, Kant jamais alega que uma ação, de outro modo moralmente louvável, perde sua importância moral se um agente tem uma inclinação para realizá-la. Sua afirmação é antes a de que uma ação carece de importância moral se o agente a realiza somente por causa da inclinação. Portanto, a distinção entre uma ação ser acompanhada pela inclinação (mit Neigung) e ser motivada pela inclinação ou derivada dela (aus Neigung) é um componente essencial da psicologia moral de Kant. ${ }^{12}$

Enquanto Allison defende a possibilidade de uma ação com conteúdo moral realizada com incentivo da sensibilidade, e de uma boa vontade formada por inclinações, Paton (1971, p.46, grifo do autor, tradução nossa), por sua vez, parece discordar desta posição: "Uma boa vontade, sob condições humanas, é aquela que é realizada por causa do dever". ${ }^{13}$

E com Paton concorda Tugendhat (1999, p.122):

12 "In fact, Kant never claims that an otherwise morally praiseworthy act loses its moral significance if an agent has an inclination to perform it. His claim is rather that such an act lacks moral significance if the agent performs it only because of the inclination. Thus, the distinction between an act being accompanied by inclination ( mit Neigung) and being motivated by or from inclination (aus Neigung) is an essential component of Kant's moral psychology."

13 "A good will under human conditions is one which acts for the sake of duty." 
Se agora se diz ainda, não poder, o valor da ação, ser adicionalmente influenciado por inclinações, então isto quer dizer apenas justamente não poderem de modo algum outros fatores desempenhar uma função, com outras palavras, que só pode ser boa a ação, cujo único motivo é o dever (o bem), ou, formulado com mais cautela: mesmo que possam estar em jogo outros motivos (inclinações), para a avaliação moral das ações só é relevante, se o motivo moral foi decisivo.

Na Fundamentação, Kant (2005, p.46) explicitamente deixa claro que são necessárias a coerção e dominação das inclinações para que possamos agir moralmente, e que, portanto, para realizar uma ação moral a vontade tem de ser motivada pelo puro dever.

Pois a pura representação do dever e em geral da lei moral, que não anda misturada com nenhum acrescento de estímulos empíricos, tem sobre o coração humano, por intermédio exclusivo da razão (que só então se dá conta de que por si mesma também pode ser prática), uma influência muito mais poderosa do que todos os outros móbiles que se possam ir buscar ao campo empírico, em tal grau que, na consciência da sua dignidade, pode desprezar estes últimos e dominá-los pouco a pouco. Em vez disto uma doutrina dos costumes mesclada, composta de móbiles de sentimentos e inclinações ao mesmo tempo que de conceitos racionais, tem de fazer vacilar o ânimo em face de motivos impossíveis de reportar a princípio algum, que só muito casualmente levam ao bem, mas muitas vezes podem levar também ao mal.

Desse modo, a interpretação de Allison destaca-se contrariamente ao rigorismo da ética kantiana, segundo a qual não admite e até menospreza a influência da sensibilidade na realização de ações que possam vir a ter conteúdo moral, e confronta-se com os argumentos da Fundamentação, na qual Kant (2005, p.65) expõe de modo radical sua posição: 
Tudo portanto o que é empírico é, como acrescento ao princípio da moralidade, não só inútil mas também altamente prejudicial à pureza dos costumes; pois o que constitui o valor particular de uma vontade absolutamente boa, valor superior a todo o preço, é que o princípio da acção seja livre de todas as influências de motivos contingentes que só a experiência pode fornecer.

Atribuir moralidade a ações que evidentemente possuam mescla com o empírico significa destituir a ética do dever por uma ética hedonista fundada na satisfação da inclinação. E Kant (idem, p.46) enfatiza "que exactamente nesta pureza de sua origem reside sua dignidade para nos servirem de princípios práticos supremos; que cada vez que lhes acrescentemos qualquer coisa de empírico diminuímos em igual medida sua pura influência e o valor ilimitado das acções”. Caso haja mescla com princípios empíricos dificilmente seria possível criar disposições morais e implantálas no ânimo do homem, por esta razão, o desejo de todos os homens deveria ser o de se libertar das inclinações.

Todos os objectos das inclinações têm somente um valor condicional, pois, se não existissem as inclinações e as necessidades que nelas se baseiam, o seu objecto seria sem valor. As próprias inclinações, porém, como fontes das necessidades, estão tão longe de ter um valor absoluto que as torne desejáveis em si mesmas, que, muito pelo contrário, o desejo universal de todos os seres racionais deve ser o de se libertar totalmente delas. Portanto o valor de todos os objectos que possamos adquirir pelas nossas acções é sempre condicional. (idem, p.68, grifo do autor).

Ora, na medida em que tanto as inclinações quanto a lei se apresentam ao arbítrio como um motivo, e por conta de o homem buscar a felicidade como fonte de satisfação, as inclinações parecem constituir em si mesmas um motivo 
mais forte. Será preciso, pois, desvendar o que a lei efetiva no ânimo para que ela seja a escolhida como fundamento de determinação da vontade.

\section{O sentimento de respeito}

Todo ente dotado de razão e sensibilidade tem a obrigação de fazer que sua ação seja efetuada por dever, bem como fazer que sua máxima possa ser elevada a princípio universal de conduta. Esta obrigatoriedade torna-se necessária à vontade de um ente racional que, diante dos obstáculos impostos pelos impulsos sensíveis, tenha de ser motivada pela lei para a realização de ações com conteúdo moral.

Mas face aos obstáculos sensíveis, se o homem, por sua vez, contrastar a lei moral com suas inclinações, notadamente, a lei, por conta de sua pureza e autenticidade, reluzirá com um brilho mais forte, pois, como afirma Kant (2003, p.259), "a lei moral inevitavelmente humilha todo homem na medida em que ele compara com ela a propensão sensível de sua natureza".

Desse modo, torna-se impossível a qualquer ente racional simplesmente desprezar a lei. Independentemente do caráter, todo homem, em sua parte racional, não pode se furtar à existência de uma lei válida como um imperativo categórico. Diz, Kant (1992, p.42):

O homem (inclusive o pior), seja em que máximas for, não renuncia à lei moral, por assim dizer, rebelando-se (como recusa da obediência). Pelo contrário, a lei moral impõe-se-lhe irresistivelmente por força da sua disposição moral; e, se nenhum outro móbil actuasse em sentido contrário, ele admitila-ia na sua máxima suprema como motivo determinante suficiente do arbítrio. 
Vale observar, contudo, que muito embora seja impossível ao homem renunciar à lei, cabe a seu arbítrio decidir agir em conformidade ou não a ela. É isso que defende Almeida (1997, p.175): "O ponto central da filosofia moral kantiana, que é a explicação do dever moral como um 'imperativo categórico', está baseado na ideia de que não depende de nosso arbítrio ter ou não ter obrigações morais, muito embora dependa de uma decisão nossa agir ou não em conformidade com elas".

O homem que escolhe agir em conformidade a seus impulsos sensíveis coloca - como já foi visto - a felicidade própria como fundamento de determinação da vontade. E fazer de si mesmo regra prática universal de conduta implica a elevação da alta estima, ato que Kant (2003, p.257, grifo do autor) denomina na segunda Crítica de presunção.

Esta propensão ${ }^{14}$ a fazer de si mesmo, como base nos fundamentos determinantes subjetivos de seu arbítrio, o fundamento determinante objetivo da vontade em geral pode ser chamada de amor de si, o qual, se se converte em legislativo e em princípio prático incondicionado, pode ser chamado de presunção.

No entanto, a vontade cujo fundamento determinante é o dever, na medida em que está fundada em uma lei pura que contém a objetividade necessária de um princípio de conduta que se pretenda universal, rompe em absoluto com a presunção e até a limita ou a abate.

Visto que é impossível ao sujeito simplesmente renunciar ao imperativo, e quando a lei moral se impõe ao homem em sua pureza e autenticidade abatendo em absoluto a presunção, ela efetua no ânimo dois tipos de sentimento. $\mathrm{O}$ primeiro é negativo, na medida em que a lei moral produz

14 Propensão é um conceito definido por Kant como "a predisposição para a ânsia de uma fruição” (Kant, 1992, p.34). 
um sentimento de dor e humilhação ao forçar um rompimento com todas as inclinações sensíveis. O efeito positivo engendrado no homem pela lei pode ser denominado sentimento de respeito.

$\mathrm{Na}$ Fundamentação, o sentimento de respeito constitui o elo entre os conceitos de boa vontade, dever, imperativo, lei moral, bem como se apresenta como peça fundamental no processo de motivação moral. Afirma Rohden (1981, p.80, grifo do autor): "Kant pensa que, se não podemos saber como a lei torna-se motivo moral, podemos pelo menos saber o que ela como motivo produz no ânimo".

No entanto, como explicar a existência de um sentimento no processo de motivação moral, se até o presente momento mostramos que Kant defende a tese da pureza dos princípios na determinação da vontade?

Segundo Kant, o sentimento de respeito é produzido exclusivamente pela razão prática pura e, portanto, não pode chamar-se de um sentimento patologicamente produzido, mas sim de um sentimento prático. Kant (2005, p.32, nota, grifo do autor) afirma que, "embora o respeito seja um sentimento, não é um sentimento recebido por influência; é, pelo contrário, um sentimento que se produz por si mesmo através dum conceito da razão, e assim é especificamente distinto de todos os sentimentos do primeiro género que se podem reportar à inclinação ou ao medo".

Todavia, se o ser racional não fosse também composto de sensibilidade, então ele não poderia sentir respeito. Primeiro, porque, um ser racional puro, como a divindade, por conta de sua condição, acata inevitavelmente a voz da razão pura, e, neste caso, não há obstáculos subjetivos aos quais se opor. Segundo, não havendo inclinações, dissipa-se a necessidade de abater a presunção, e sendo o sentimento de respeito engendrado a partir de uma determinação que controla as inclinações, torna-se impossível sentir respeito sem possuir uma natureza sensível. 
Por conta de o homem constituir-se como ser ambivalente, o processo de determinação da vontade pela lei moral dá-se de modo diferente. Quando o homem reconhece que a razão lhe oferece uma lei autêntica e pura, de valor muito mais elevado que as inclinações, ele é tomado por um sentimento de respeito a esta lei, e a consciência da determinação imediata da vontade de um ente racional por esta lei pura, que contém uma parte sensível, a qual tem de dominar para agir moralmente, nada mais é que a representação desse respeito.

Aquilo que eu reconheço imediatamente como lei para mim, reconheço-o com um sentimento de respeito que não significa senão a consciência da subordinação da minha vontade a uma lei, sem intervenção de outras influências sobre a minha sensibilidade. A determinação imediata da vontade pela lei e a consciência desta determinação é que se chama respeito, de modo que se deve ver o efeito da lei sobre o sujeito e não a sua causa. (idem, p.32, nota, grifo do autor).

É importante observar, como faz Reath (1989, p.289, tradução nossa), dois aspectos do sentimento de respeito:

Daquelas inclinações que são mantidas em controle simplesmente pelo reconhecimento da Lei Moral (o aspecto intelectual do respeito) e sua interação entre razão prática e sensibilidade surge o sentimento de respeito (o aspecto afetivo). O resultado da emoção moral acaba sendo alguma coisa como o modo pelo qual nós experimentamos a atividade da razão prática pura. ${ }^{15}$

15 "One's inclinations are held in check simply by recognition of the Moral Law (the intellectual aspect of respect), and this interaction between practical reason and sensibility gives rise to the feeling of respect (the affective aspect). The resulting moral emotion ends up being something like the way in which we experience the activity of pure practical reason." 
Kant, portanto, denomina o respeito produzido pela lei de sentimento moral. Mas seria então o sentimento de respeito o motivo moral? Se assim for, ou seja, se o respeito constituir o motivo determinante de uma vontade moral, então Kant estará se utilizando de um sentimento como fundamento a isso. Ora, isso seria contrário ao que dissemos até o presente momento sobre a filosofia moral kantiana, portanto, Kant (2003, p.248-9, grifo do autor) não pode recorrer a este artifício porque seria admitir que as escolhas humanas tenham, em última instância, um fundamento empírico, na sensibilidade.

Com efeito, se a determinação da vontade acontecer conforme à lei moral, mas somente através de um sentimento, seja ele de que espécie for [sensível ou intelectual] e que tenha de ser pressuposto para que a lei moral se torne um fundamento determinante suficiente da vontade, por conseguinte não por causa da lei, nesse caso a ação em verdade conterá legalidade mas não moralidade.

Então, como devemos compreender a relação entre a lei e o sentimento de respeito na determinação da vontade moral? Para Kant (p.35, grifo do autor), "a razão exige-me respeito por uma legislação, a qual em verdade presentemente não vejo em que se funde [...], mas de que pelo menos compreendo que é uma apreciação do valor que de longe ultrapassa o de tudo aquilo que a inclinação louva".

É preciso, portanto, observar que somente a lei pode servir como motivo objetivo moral e que o sentimento de respeito nada mais é aquilo que a lei efetiva no ânimo do ente racional quando o mesmo toma consciência de sua moralidade.

Reath (1989, p.290, tradução nossa) explica "que respeito não é um "incentivo para a moralidade", mas a Lei Moral em si mesma é considerada como um incentivo [...]. 
Além disso, o que queremos dizer, embora um sentimento seja produzido quando a Lei Moral determina a vontade, não é este sentimento que motiva" ${ }^{16}$

Para Kant (2005, p.31):

Só pode ser objecto de respeito e portanto mandamento aquilo que está ligado à minha vontade somente como princípio e nunca como efeito, não aquilo que serve à minha inclinação mas o que a domina ou que, pelo menos, a exclui do cálculo na escolha, quer dizer a simples lei por si mesma.

Portanto, ao produzir no sujeito um sentimento puro, denominado respeito, a lei não só abate a presunção como se torna, ela mesma, um motivo para o arbítrio.

O respeito é propriamente a representação de um valor que causa dano ao meu amor-próprio. É portanto alguma coisa que não pode ser considerada como objecto nem da inclinação nem do temor, embora tenha algo de análogo com ambos simultaneamente. O objecto do respeito é portanto simplesmente a lei, quero dizer aquela lei que nos impomos a nós mesmos, e no entanto como necessária em si. Como lei que é, estamo-lhes subordinados, sem termos que consultar o amorpróprio; mas como lei que nós nos impomos a nós mesmos, é ela uma conseqüência da nossa vontade e tem, de um lado, analogia com o temor, e, do outro, com a inclinação. (idem, p.32, nota, grifo do autor).

Ora, se por motivo Kant compreende o fundamento determinante objetivo da vontade de um ente, e móbil o fundamento subjetivo, todo ente racional encontra na lei

16 "that respect is not an "incentive to morality", but the Moral Law itself regarded as an incentive [...]. In addition, we saw that, while an affect is produced when the Moral Law determines the will, it is not this affect that motivates." 
um motivo para agir moralmente, sendo o respeito o móbil necessário que faltava à determinação moral. Desse modo, a lei engendra um motivo mais forte para determinar a vontade do que a própria inclinação sensível, pois, concomitantemente, oferece um móbil à vontade. Como afirma Kant (2005, p.85), "não é nem o medo nem a inclinação, mas tãosomente o respeito à lei que constitui o móbil que pode dar à acção um valor moral". O respeito seria o móbil, um fundamento subjetivo, pois o motivo, ou seja, o fundamento objetivo seria a lei em si mesma.

Desse modo, a Fundamentação ensina "que a necessidade das minhas ações por puro respeito à lei prática é o que constitui o dever, perante o qual tem de ceder qualquer outro motivo, porque ele é a condição de uma vontade boa em si, cujo valor é superior a tudo" (idem, p.35, grifo do autor).

A lei moral, portanto, pode constituir um motivo para a determinação do arbítrio, na medida em que ela efetua no ânimo um sentimento puro, denominado respeito, ao qual todo homem está sujeito a sentir. É através desse sentimento que a vontade se submete livremente à determinação pela lei. "Ora, a consciência de uma livre submissão da vontade à lei, contudo vinculada a uma inevitável coerção que é exercida sobre todas as inclinações, porém apenas pela própria razão, é o respeito pela lei” (Kant, 2003, p.279-81, grifo do autor).

Kant, desse modo, procura mostrar que a lei moral não determina a vontade por meio de um ato quase mecânico. Não é de forma imediata, como um ato espontâneo e exato, como podemos averiguar na equação em que dois mais dois são quatro. Não obstante, há um processo pelo qual o sujeito pode ou não reconhecer a lei moral como um motivo de dela sentir respeito.

Para tanto, notemos que é necessária a coerção do sujeito frente às inclinações sensíveis, pois elas são concorren- 
tes ao sentimento de respeito na determinação da vontade, já que se apresentam como fortes obstáculos subjetivos. Segundo Reath (1989, p.301, tradução nossa):

Kant pensa que estas tendências motivacionais estão profundamente enraizadas em nossa natureza e que elas estão sempre presentes. E devem ser mantidas sob controle se agirmos a partir de um motivo moral. Então o reconhecimento imediato da Lei Moral é sempre o reconhecimento de uma forma de valor que torna necessária uma desvalorização das inclinações. ${ }^{17}$

E um sujeito que age por motivações de ordem das emoções pode até não ser um mau sujeito, mas por depender de princípios externos para a formação de seu caráter, ele não inspira o respeito.

Todo o respeito por uma pessoa é propriamente só respeito pela lei (lei da rectidão, etc.), da qual essa pessoa nos dá o exemplo. Porque consideramos também o alargamento dos nossos talentos como um dever, representamo-nos igualmente numa pessoa de talento por assim dizer o exemplo duma lei (a de nos tornarmos semelhantes a ela por meio do exercício), e é isso que constitui o nosso respeito. (Kant, 2005, p.32, nota, grifo do autor).

Kant é convicto de que a lei moral precisa ser apresentada completamente pura e sem referência aos motivos sensíveis, com isso ela pode estender em nós toda sua força motivacional. Evidentemente Kant pensa que isso ocorre

17 "Kant thinks that these motivational tendencies are so deeply rooted in our nature that they are always present, and must be held in check whenever one acts from a moral motive. Thus the immediate recognition of the Moral Law is always the recognition of a form of value that entails a devaluation of the inclinations." 
na forma de um sentimento, o de respeito, que representa o móbil subjetivo para a escolha do sujeito. Desse modo Kant (2003, p.283) conclui: "Portanto o conceito de dever exige na ação, objetivamente, concordância com a lei, mas em sua máxima, subjetivamente, respeito pela lei, como o único modo de determinação da vontade pela lei”. Assim, a lei constitui-se como um motivo objetivo, que produz subjetivamente um sentimento, o móbil da ação moral.

Mas, do conceito de motivo, surge o de interesse, e deve também ser analisada a forma em que ele interfere no processo motivacional. 



\section{4 \\ INTERESSE DA RAZÃO E LIBERDADE}

A lei em sua pureza e autenticidade comparada à condição humana, inevitavelmente, humilha e abate a presunção, efetuando no ânimo um sentimento de respeito que se tornará o móbil da ação, tornando-se, desse modo, o único motivo pelo qual um ente racional pode agir moralmente. Portanto, uma ação realizada eticamente não pode ter sido motivada objetivamente por outra coisa senão pela lei em si mesma, e subjetivamente pelo sentimento de respeito que ela produz.

Mas como podemos mensurar uma ação e afirmar que ela foi realizada ou não por respeito à lei? Kant dirá que a moralidade se fundamenta em princípios que não se veem, e o que conta na ação é a intenção que está por trás do agir. A intenção, por sua vez, está ligada ao interesse que o homem tem na realização da ação, que pode se tratar de um interesse estrito na realização da ação ou um interesse com vistas a um outro fim.

Neste contexto, embora a lei se apresente para o ente racional como um motivo determinante da vontade, cabe ainda uma questão: Por que todo ser racional deve se submeter a esta lei? De que forma esta lei pode causar interes- 
se no homem que tem diante de si as solicitações dos desejos sensíveis?

O presente capítulo pretende mostrar que a lei moral interessa ao homem, porque ela é um produto de sua razão, isto é, efeito de sua liberdade enquanto um ente do mundo inteligível.

\section{A intenção que anda ligada com o interesse}

Na ética kantiana, uma ação para conter conteúdo moral tem de ser motivada, de modo objetivo, pela lei e subjetivamente pelo sentimento de respeito que a consciência da pureza desta lei engendra no sujeito. Desse modo, o que está em jogo no julgamento da ação não é exatamente aquilo que a ação promove, ou seja, o seu efeito, mas, a forma pela qual a vontade foi determinada, isto é, a causa da ação. Segundo Tugendhat (1996, p.117): "Kant insiste em que nós só julgamos moralmente o querer que determina uma ação, e que nosso juízo não depende de a ação ter sucesso".

Surge, porém, um problema: como podemos julgar a causa de uma ação se ela não é palpável, visível, isto é, empírica? Com efeito, qual juiz seria capaz de determinar a validade moral de uma ação se o que conta para a avaliação se assenta em algo de subjetivo?

Como o próprio Kant (2005, p.40) afirma: “é absolutamente impossível encontrar na experiência com perfeita certeza um único caso em que a máxima de uma ação, de resto conforme ao dever, se tenha baseado puramente em motivos morais e na representação do dever”. Então, fica a pergunta: se não podemos determinar empiricamente se uma ação foi realizada ou não por dever, como julgar a ação? A resposta que parece mais plausível: a intenção é que conta. 
Gostamos de lisonjear-nos então com um móbil mais nobre que falsamente nos arrogamos; mas em realidade, mesmo pelo exame mais esforçado, nunca podemos penetrar completamente até aos móbiles secretos dos nossos actos, porque, quando se fala de valor moral, não é das acções visíveis que se trata, mas dos seus princípios íntimos que se não veem.

Eis o limite da compreensão humana acerca do processo motivacional da vontade. Definir que o motivo da ação tenha sido exclusivamente o princípio do dever ou que a mesma tenha sido motivada pelo princípio egoísta, é algo que ultrapassa de longe todo o alcance do entendimento humano, pois a escolha do princípio determinante da vontade, ou seja, do motivo, não é um ato empírico. E como Kant ensina na primeira Crítica que todo o nosso conhecimento se limita a meros fenômenos, aquilo que não é fenômeno não pode ser apreendido por nosso entendimento.

Desse modo, Kant (2005, p.39, "intenção” é grifo nosso) afirma:

Quando atentamos na experiência humana de fazer ou deixar de fazer, encontramos queixas freqüentes e, como nós mesmos concedemos, justas, de que se não podem apresentar nenhuns exemplos seguros da intenção de agir por puro dever; porque, embora muitas das coisas que o dever ordena possam acontecer em conformidade com ele, é contudo ainda duvidoso que elas aconteçam verdadeiramente por dever e que tenham portanto valor moral.

Muitas das ações realizadas pelo homem podem conter legalidade, ou seja, podem estar em conformidade com a lei, o que não significa que a ação teve como fundamento o puro dever. A ação pode ter sido realizada por uma inclinação imediata do sujeito, que muito embora não seja contrária ao dever, também não está fundada na observância da lei em si mesma, pois admite a influência de elementos externos. 
Temos, portanto, de estar sempre atentos ao examinar o motivo determinante da ação. Pode ocorrer que naquelas ações julgadas pelo sucesso de seus efeitos, aparentemente haja conteúdo moral, mas, a partir de um exame mais minucioso, demonstrem ser causadas por uma intenção estritamente egoísta.

Quero por amor humano conceder que ainda a maior parte das nossas acções são conformes ao dever; mas se examinarmos mais de perto as suas aspirações e esforços, toparemos por toda a parte o querido Eu que sobressai, e é nele, e não no severo mandamento do dever que muitas vezes exigiria a auto-renúncia, que a sua intenção se apóia. (idem, p.41, grifo nosso)

Dada a impossibilidade de julgar propriamente qual o motivo determinante da vontade de um ente racional, pois seria um ato que ultrapassaria o limite do entendimento humano, estamos restritos à análise da intenção que move a ação. Visto que a intenção, na maioria dos casos, está fundada no princípio egoísta em vez de no princípio do dever, como fica a teoria motivacional de Kant, já que mesmo tendo o sujeito agido motivado pela lei, nunca teremos o conhecimento certo disso?

Embora Kant mostre a impossibilidade de determinarse empiricamente o motivo da ação do sujeito, na Fundamentação ele procura relacionar a intenção que move a ação ao conceito de interesse, e mostra que, mesmo não podendo conhecer o motivo determinante da ação, há a possibilidade de julgarmos a ação a partir do interesse esboçado pelo sujeito na realização da ação. 


\section{O interesse da razão prática}

Vimos que a lei se torna um motivo a partir da consciência moral que o sujeito racional toma ao contrastar sua condição com a pureza da lei. A partir daí, a lei efetiva no ânimo um sentimento de respeito que se torna o móbil subjetivo da ação e faz que a máxima possa ser elevada à universalidade. Mas, empiricamente, pela falta de exemplos seguros, é impossível determinar se realmente a ação foi motivada pela lei tendo como móbil o respeito, restando apenas verificar se a intenção do agir foi exclusivamente fundada na ação ou com vistas a seu efeito.

Para Kant (2003, p.277, grifo do autor), no entanto, o conceito de motivo está estritamente relacionado ao conceito de interesse. "Do conceito de motivo surge o de interes$s e$, que jamais pode ser atribuído senão a um ente dotado de razão e significa um motivo da vontade, na medida em que este é representado pela razão".

Rohden (1981, p.75) afirma ainda que o motivo é essencial, mas por si só insuficiente, pois a determinação subjetiva da vontade passa pelo interesse do sujeito na realização da ação.

O motivo moral torna-se um elemento essencial da moralidade, sem o qual a concordância da ação com a lei é contingente e puramente legal. Isto não significa, contudo, que o motivo se converta em fundamento suficiente da moralidade. Como efeito, por um lado, o homem é objetivamente determinado pela lei; por outro, ele determina-se a si mesmo subjetivamente mediante o interesse por ela.

Com efeito, se a razão prática pura tem de necessariamente fundar a moralidade, cabe a Kant, então, explicar de que modo o homem toma interesse pelo princípio da razão como motivo determinante da vontade em face das exigên- 
cias das inclinações originadas pela sensibilidade. Para Tugendhat (1996, p.130), a questão "é que pode ser caracterizado como moral, e, portanto, como bom, somente o agir que é determinado exclusivamente pela motivação moral". Diante de duas fontes de motivação, como pode o homem tomar interesse pelo motivo racional?

Kant (2005, p.49, nota, grifo ao autor) define interesse do seguinte modo:

Chama-se interesse a dependência em que uma vontade contingentemente determinável se encontra em face dos princípios da razão. Este interesse só tem pois lugar numa vontade dependente que não é por si mesma em todo o tempo conforme à razão; na vontade divina não se pode conceber nenhum interesse.

Se ser felizé a aspiração de todo ente racional, e a felicidade consiste na satisfação do conjunto de todas as inclinações que pode facilmente ser atingida pela sensibilidade, por qual motivo o homem deixaria de satisfazer seus desejos em prol da moralidade? A questão é a seguinte: como pode o homem tomar interesse pela lei e fazer dela um motivo para a escolha do arbítrio humano? Kant (2005, p.97, grifo do autor) colocou o problema do seguinte modo na Fundamentação:

Mas porque é que devo eu submeter-me a este princípio [a lei], e isso como ser racional em geral, e portanto todos os outros seres dotados de razão? Quero conceder que nenhum interesse me impele a isso, pois daí não poderia resultar nenhum imperativo categórico; e contudo tenho necessariamente que tomar interesse por isso e compreender como isso se passa.

Rohden (1981, p.63, grifo do autor) explica o conceito de interesse do seguinte modo: 
A conexão da faculdade de desejo com o prazer, enquanto ocorre mediante a razão segundo uma regra, é denominada interesse. O prazer torna-se um 'interesse da inclinação', quando se torna, segundo uma regra, o fundamento da determinação da faculdade de desejar. O prazer torna-se intelectual, e o interesse, 'interesse da razão', se o prazer for apenas uma conseqüência de uma certa determinação anterior da faculdade de desejar.

De acordo com as palavras citadas acima, podemos perceber que existem pelo menos dois tipos de interesse. Aquele que está relacionado à inclinação e ao desejo sensível de felicidade, e outro relacionado aos princípios puros da razão. Isto ocorre porque para Kant (2005, p.49, nota, grifo do autor) "a vontade humana pode tomar interesse por qualquer coisa sem por isso agir por interesse". A Fundamentação estabelece a seguinte diferença entre o tomar interesse e agir por interesse:

O primeiro significa o interesse prático na acção, o segundo o interesse patológico no objeto da acção. O primeiro mostra apenas dependência da vontade em face dos princípios da razão em si mesmos, o segundo em face dos princípios da razão em proveito da inclinação, pois aqui a razão dá apenas a regra prática para socorrer a necessidade da inclinação. No primeiro caso interessa-me a acção, no segundo o objecto da acção (enquanto ele me é agradável). [...] numa acção praticada por dever se não tem de atender ao interesse pelo objecto, mas somente à própria acção e ao seu princípio na razão (à lei). (idem, nota, grifo do autor)

Todo o interesse patológico promete uma contribuição para o bem-estar e da felicidade do próprio sujeito por meio do agrado que a realização da ação nele produzirá, quer imediatamente e sem intuito de vantagem, quer com referência a esta vantagem. Neste caso, o interesse do sujeito é 
pelo efeito que a ação produzirá, sem se preocupar propriamente se ela terá ou não valor moral.

O interesse prático, por sua vez, refere-se a um interesse do sujeito em realizar a ação exclusivamente por causa da lei, sem a influência de elementos exteriores, e sem pensar no efeito que a ação produzirá para promover sua felicidade. Neste caso interessa ao sujeito somente a lei, pois o interesse é pela ação naquilo que ela representa em si mesma como uma obrigação e não pelo efeito que dela sucede. Trata-se de um interesse racional puro, e por isso podemos chamá-lo de um interesse moral. "Visto que numa vontade moralmente boa a própria lei tem que ser o motivo, o interesse moral é um interesse não sensorial puro da simples razão prática” (Kant, 2003, p.277, grifo do autor).

Temos, portanto, segundo Rohden (1981, p.63-4), o seguinte quadro:

No primeiro caso [interesse empírico], o prazer torna-se o fundamento determinante do interesse, e a razão representa-se através de um imperativo hipotético apenas a condição do fim a ser alcançado. No segundo caso [interesse prático], a razão determina sozinha o interesse, e determina os princípios (ou as leis) do interesse de modo tal, que o prazer passa a ser simples conseqüência da determinação da lei.

Kant qualifica a renúncia a todo interesse no querer por dever como o caráter específico de distinção do imperativo categórico em face do hipotético. Pois se um sujeito fosse ligado ao imperativo categórico por meio de um interesse empírico, então este imperativo poderia sempre ligar uma pessoa em si só sob a condição deste interesse. Enquanto o imperativo hipotético possui um interesse em sua base, o imperativo categórico exclui qualquer condição, pois tal imperativo é incondicionado.

Segundo essa concepção, seria portanto um mundo representável no qual Deus promulga uma lei moral e man- 
tém o homem nessa lei só porque ele tem medo do castigo ou espera ver recompensada sua lealdade à lei de Deus. Não existiria imperativo categórico se os homens pudessem seguir a lei moral sozinhos a partir do interesse próprio. Ele só é possível se o homem, independente de todos os interesses empíricos, for ligado à lei moral.

A solução de todos os interesses para o querer a partir do dever não diz, assim, que a vontade de uma pessoa de forma alguma é ligada por meio de interesses à lei moral. Precisamente aqui, porém, não se trata de um interesse empírico na efetivação de um posicionamento de interesse impulsivo. Ao contrário, Kant escolhe a expressão interesse moral. Logo uma pessoa tem um interesse moral na voz da razão prática, se ela age a partir do respeito pela lei moral. A questão - por que uma pessoa age moralmente esclarece-se, portanto, somente pelo fato de ela querer ser racional.

Por esta razão, Kant (2005, p.88, grifo do autor) afirma que "o sentimento moral, este pretenso sentido especial [...] está, contudo, mais perto da moralidade e de sua dignidade, porque tributa à virtude a honra de lhe atribuir imediatamente a satisfação e o respeito por ela e não lhe diz na cara que não é sua beleza, mas somente o interesse, que a ela nos liga".

Fica, portanto, estabelecido que o interesse do sujeito, para ser considerado moral, tem objetivamente de ser necessariamente pela lei e, desse modo, agir segundo as prescrições do imperativo categórico, bem como subjetivamente o interesse pelo móbil da ação não pode ser outro senão o respeito pela lei.

Assim o princípio, segundo o qual toda a vontade humana seria uma vontade legisladora universal por meio de todas as suas máximas, se fosse seguramente estabelecido, conviria perfeitamente ao imperativo categórico no sentido de que, 
exactamente por causa da idéia da legislação universal, ele se não funda em nenhum interesse, e portanto, de entre todos os imperativos possíveis, é o único que pode ser incondicional; [...] pois só então é que o princípio prático e o imperativo a que obedece podem ser incondicionais, porque não têm interesse algum sobre que se fundem. (idem, p.74, grifo do autor)

Mas o fato de o homem como ente sensível nem sempre seguir a lei moral resulta de que ele frequentemente põe como fundamento de suas máximas não os interesses da razão, mas os interesses das inclinações. Enquanto estes interesses representam uma dependência da faculdade de desejar de sensações de objetos, o interesse da razão implica uma determinação da vontade independente de estímulos exteriores que não seja o princípio da razão.

Neste sentido, Almeida (1997, p.175) afirma que "a ideia de um dever incondicional é a mais difícil de fundamentar na filosofia moral kantiana, pois exige precisamente que se pense a motivação moral como independente de todo móvel ou estímulo sensível, portanto, de tudo o que se possa desejar e até mesmo da aspiração à felicidade”.

$\mathrm{Na}$ Fundamentação, o próprio Kant (2005, p.113, grifo do autor) diz:

É-nos totalmente impossível a nós homens explicar como e porquê nos interessa a universalidade da máxima como lei, e, portanto, a moralidade. Apenas uma coisa é certa: [...] interessa porque é válida para nós como homens, pois que nasceu da nossa vontade, como inteligência, e portanto do nosso verdadeiro eu; mas o que pertence ao simples fenómeno é necessariamente subordinado pela razão à constituição da coisa em si mesma.

Para Kant, portanto, este é o limite de nosso conhecimento, isto é, não é possível mostrar como tomamos interesse pela lei moral, embora seja certo que tomamos inte- 
resse por ela. Mas a pergunta persiste: por que tomamos interesse pela lei? Segundo Almeida (1997, p.175), a resposta mais plausível é "porque isso é uma condição do valor que nos atribuímos e da consciência que temos de nós mesmos como seres racionais". Segundo Rohden (1981, p.66):

O interesse da razão não pode ser imposto. O homem é capaz de sentir interesse por uma exigência da razão, mas o interesse não é uma exigência e sim um ato livre. Quer dizer, o interesse pelo bom tem que ser expressado de uma pessoa agindo de modo racionalmente livre. Enquanto o homem é razão, ele toma ou é capaz de tomar um interesse absoluto pelo bom, isto é, por aquilo que é bom em todos os sentidos e para qualquer ente racional.

Segundo Almeida $(1997,175)$, esteé o ponto central da ética kantiana:

O ponto central da filosofia kantiana, que é a explicação do dever moral como um 'imperativo categórico', está baseado na idéia de que não depende de nosso arbítrio ter ou não ter obrigações morais, muito embora dependa de uma decisão nossa agir ou não em conformidade com elas.

Portanto, resta a Kant ainda responder qual é o fundamento dessas obrigações incondicionais. A reposta parece estar ligada ao conceito de liberdade, e isto é o que investigaremos a seguir.

\section{A liberdade}

O conceito de liberdade é indispensável para a fundamentação da moral. Somente é possível julgar as ações humanas sob uma perspectiva ética, se pudermos pressupor 
que foram realizadas de acordo com uma vontade livre. É impossível imputar responsabilidade moral a uma ação necessariamente causada por uma determinação distinta da causalidade por liberdade.

Se não pudéssemos pressupor a liberdade como causalidade de um ser racional, então seria o mesmo que admitir que este ser age por força de causas estranhas ou por impulsos alheios, e não por intermédio da razão. A razão tem de considerar-se a si mesma como a autora de seus próprios princípios, por isso, ele tem de considerar-se como livre, sendo, portanto, a vontade de todo ente racional uma vontade livre, ou seja, que age segundo a ideia da liberdade. Temos, portanto, de pressupor a liberdade para podermos imputar responsabilidade às ações humanas, caso contrário não haveria meios de tornar o homem consciente de suas ações.

Todavia, admitir a liberdade como causalidade em um mundo ordenado por leis naturais constitui um problema. E em face da indispensabilidade da liberdade para a fundamentação da moral, faz-se necessário mostrar como ela pode ser compatível com o mecanismo da natureza. Esta tarefa foi, de certo modo, realizada por Kant na Crítica da razão pura com o ensinamento de que devemos sempre tomar os objetos em uma dupla significação, a saber, como fenômenos e como númenos.

A distinção dos objetos entre fenômeno e númeno possui um caráter essencial para a filosofia transcendental, pois a partir desta distinção se impõe ao conhecimento humano um limite. Após a crítica especulativa, o sujeito ficou limitado a conhecer apenas aquilo que é dado a ele pela natureza sob a condição de fenômeno e passível de subsunção sob um conceito do entendimento; consequentemente, o acesso às coisas em si mesmas está irremediavelmente bloqueado. 
Ora, onde cessa a determinação segundo leis naturais, cessa também toda a explicação, e nada mais resta senão a defesa, isto é, a repulsão das objecções daqueles que pretendem ter visto mais fundo na essência das coisas e por isso atrevidamente declaram a liberdade impossível. (Kant, 2005, p.111, grifo do autor)

Por isso Kant (idem, p.106, grifo do autor) defende que "a liberdade é apenas uma ideia da razão cuja realidade objectiva é em si duvidosa; a natureza, porém, é um conceito do entendimento que demonstra, e tem necessariamente de demonstrar, sua realidade por exemplos da experiência". Explicar como é possível a liberdade, é algo que ultrapassa de longe todos os limites da razão humana.

A impossibilidade subjectiva de explicar a liberdade da vontade é idêntica à impossibilidade de descobrir e tornar concebível um interesse que o homem possa tomar pelas leis morais; e, no entanto, é um facto que ele toma realmente interesse por elas, cujo fundamento em nós é o que chamamos sentimento moral. (idem, p.112, grifo do autor)

Mas, ainda que possamos pensar a liberdade, uma pergunta permanece: como conciliá-la com o mecanismo da natureza? Tal questão está inserida na primeira Crítica no âmbito das "Antinomias da razão pura", no qual a questão é posta em termos cosmológicos. O problema surge quando a razão busca encontrar o incondicionado na série de condições causais para qualquer ocorrência dada e depara inevitavelmente com duas alternativas: a de admitir a tese que argumenta a favor da existência de efeitos no mundo produzidos espontaneamente, ou seja, por liberdade, ou então a antítese, que argumenta a favor do determinismo natural.

A solução crítica para este impasse é considerar a liberdade neste primeiro momento como transcendental. Para 
Kant (1980, p.272, B 561), a liberdade, no sentido prático, funda-se nesta ideia da liberdade transcendental: "É sobremaneira digno de nota que o conceito prático de liberdade se funda nesta ideia transcendental da mesma e que esta última constitui naquela o momento próprio das dificuldades que desde sempre envolveram a questão sobre sua possibilidade".

Kant (1980, p.271, B 561) define a liberdade transcendental do seguinte modo:

Entendo por liberdade, em seu sentido cosmológico, a faculdade de iniciar espontaneamente um estado, e cuja causalidade, pois, não está por sua vez, como o requer a lei da natureza, sob uma outra causa que a determine quanto ao tempo. Neste significado, a liberdade é uma idéia transcendental pura, que, em primeiro lugar, não contém nada emprestado da experiência e cujo objeto, em segundo lugar, também não pode ser dado determinadamente em nenhuma outra experiência.

Antes, portanto, de nos atermos ao conceito de liberdade em seu sentido prático, já que este conceito é o que mais nos interessa no âmbito da moralidade, será preciso compreender que tanto a liberdade transcendental quanto a causalidade natural podem ser pensadas sem contradição. "Há pois que pressupor que entre liberdade e necessidade natural dessas mesmas acções humanas se não encontra nenhuma verdadeira contradição; pois não se pode renunciar nem ao conceito da natureza nem ao da liberdade" (Kant, 2005, p.107).

No capítulo Cânone, da Crítica da razão pura, Kant trata da liberdade como um conceito negativo e restritivo, denominando-o, como dito acima, transcendental. $\mathrm{Na}$ Fundamentação, a liberdade prática, considerada uma ideia, pode ser pensada pelo sujeito como existente no mundo 
ordenado pelas leis naturais, embora ele esteja fadado a ter de aceitá-la, sem, contudo, conhecê-la (em sentido especulativo). Contudo Kant (2005, p.95, grifo do autor) afirma:

Todo o ser que não pode agir senão sob a ideia da liberdade, é por isso mesmo, em sentido prático, verdadeiramente livre, quer dizer, para ele valem todas as leis que são inseparavelmente ligadas à liberdade, exactamente como se a sua vontade fosse definida como livre em si mesma e de modo válido na filosofia teórica.

Muito embora a crítica especulativa realizada por Kant encerre uma certa negatividade, por conta de limitar o conhecimento humano a meros fenômenos e de impossibilitar o acesso às coisas em si mesmas, tal crítica, por outro lado, presta um serviço de grande positividade à moral. Ao traçar os limites da razão pura especulativa, Kant (1980, p.15, B xxv), concomitantemente, mostra que esta restrição é necessária para que possa haver uma ampliação no uso prático da razão, uso que se estende naturalmente acima dos limites da sensibilidade.

Por isso, uma Crítica que limita a razão especulativa é, nesta medida, negativa; na medida em que ao mesmo tempo elimina com isso um obstáculo que limita ou até ameaça aniquilar o uso prático, de fato possui utilidade positiva muito importante tão logo se esteja convencido de que existe um uso prático absolutamente necessário da razão pura (o moral) no qual esta se estende inevitavelmente acima dos limites da sensibilidade.

Sem uma crítica que circunscrevesse a distinção entre fenômeno e númeno, todos os objetos seriam tomados pelo sujeito como coisas em si mesmas e, inevitavelmente, apenas uma única causalidade seria passível de ser admitida como causa eficiente na determinação de todos os objetos, 
a saber, a causalidade natural. "Com respeito a um mesmo ente, por exemplo, a alma humana, eu não poderia portanto dizer que sua vontade é livre e que está ao mesmo tempo submetido à necessidade natural, isto é, não livre, sem cair numa evidente contradição" (idem, p.16, B xxvii).

Mas se considerarmos a distinção proposta pela crítica especulativa, a contradição desaparece. Se a causalidade natural incide somente sobre os objetos da experiência sensível, portanto, sobre os fenômenos, o númeno pode ser pensado fora desta relação, ou seja, como ente incondicionado. Desse modo, admitir-se-á, concomitantemente, a mesma ação produzida no mundo como sendo, sob a perspectiva da sensibilidade e do interesse especulativo da razão, determinada pelo mecanismo natural e, portanto, como não livre; e do ponto de vista intelectual e do uso prático da razão, sendo considerada em si mesma como incondicionada e, portanto, livre, sem com isso incorrer em contradição.

Todo ente racional, portanto, tem de considerar-se a si mesmo e todas as suas ações sob um duplo ponto de vista:

o primeiro, enquanto pertencente ao mundo sensível, sob leis naturais (heteronomia); o segundo, como pertencente ao mundo inteligível, sob leis que, independentes da natureza, não são empíricas, mas fundadas somente na razão. Como ser racional e, portanto, pertencente ao mundo inteligível, o homem não pode pensar nunca a causalidade da sua própria vontade senão sob a ideia da liberdade, pois que independência das causas determinantes do mundo sensível (independência que a razão tem sempre de atribuir-se) é liberdade. Ora à ideia de liberdade está inseparavelmente ligado o conceito de autonomia, e a este o princípio universal da moralidade, o qual na ideia está na base de todas as acções de seres racionais como a lei natural está na base de todos os fenômenos. (Kant, 2005, p.102, grifo do autor). 
Se o sujeito é incapaz de conhecer a liberdade pelo uso especulativo da razão como um ente pertencente à natureza, isto é, como um fenômeno, ele pode ao menos pensá-la como númeno.

Como para a Moral nada mais necessito que a liberdade não se contradiga e portanto seja pelo menos pensável sem necessidade de compreendê-la ulteriormente, que portanto não oponha nenhum obstáculo ao mecanismo natural precisamente da mesma ação (tomada em outra relação), assim tanto a doutrina da moralidade como a da natureza mantém o seu lugar, o que porém não ocorreria se a Crítica não tivesse antes nos instruído sobre a nossa inevitável ignorância acerca das coisas em si mesmas e limitado a meros fenômenos tudo o que podemos conhecer teoricamente. (Kant, 1980, p.17, B xxix, grifo do autor)

Desse modo, a crítica especulativa se justifica como necessária para a fundamentação da moral, pois seria impossível conceber como compatíveis as leis da natureza e da liberdade sem a distinção entre fenômeno e númeno. Kant, por sua vez, admite a perda de terreno da razão especulativa; por outro lado, ele se vê diante de uma encruzilhada: ou restringe o conhecimento humano e a pretensão da razão pura de alcançar o incondicionado ou perde por completo a possibilidade da liberdade e de um mundo moral. A solução adotada por Kant (1980, p.17, B xxx, grifo do autor) foi a representada pela primeira alternativa: "tive que suprimir o saber para obter lugar para a fé".

$\mathrm{Na}$ Fundamentação, Kant abandona a tentativa de uma dedução do conceito de liberdade e exime-se de tentar provar sua realidade objetiva, procurando então mostrar que para a moralidade basta apenas que ela seja uma ideia possível ao ente racional. Para Rohden (1981, p.80): "A obrigação moral livra o homem da mera determinação natural 
e subordina-o a uma lei racional da liberdade". Segundo Kant (2005, p.95-6, nota, grifo do autor):

Este método de admitir como suficiente para o nosso propósito a liberdade apenas como baseada só na ideia por seres racionais nas suas acções, adopto-o para não me obrigar a demonstrar a liberdade também no sentido teórico. Pois, mesmo que este último ponto tenha que ficar indeciso, as mesmas leis que obrigariam um ser que fosse verdadeiramente livre continuariam a ser válidas para um ser que não possa agir de outro modo senão sob a ideia da sua própria liberdade. Podemos, pois, aqui libertar-nos do fardo que pesa sobre a teoria.

Se por um lado a liberdade se mostra como conceito indispensável para o sistema crítico, por outro é preciso ter em vista sua incompreensibilidade. Ainda que a objetividade da liberdade seja provada, jamais teremos por meio desta prova uma ampliação do conhecimento teórico. Trata-se apenas de um conhecimento prático e para fins práticos, ou seja, como uma causalidade determinadora da vontade em vista de um objeto desejado.

A Fundamentação deixa o seguinte ensinamento:

que em pensamentos se transpõe, por uma vontade livre de impulsos da sensibilidade, a uma ordem de coisas totalmente diferente da dos seus apetites no campo da sensibilidade, pois daquele desejo não pode ele esperar nenhum prazer dos apetites e, portanto, nenhum estado satisfatório para qualquer das suas inclinações reais ou imaginárias. (Kant, 2005, p.105)

$\mathrm{Na}$ Crítica da razão prática, Kant fundamenta a liberdade na consciência do sujeito acerca da existência da lei moral, embora ele próprio chegue a afirmar em outra passagem que a liberdade é a condição da lei moral. Para não imaginarmos inconsequências em seu pensamento, o pró- 
prio Kant (2003, p.7, grifo do autor, nota) explica que a liberdade é a razão de ser (ratio essendi) da lei moral, ao passo que a lei moral é a razão de conhecer (ratio cognoscendi) da liberdade.

Para que não se imagine encontrar aqui inconsequências, quando agora denomino a liberdade condição da lei moral e depois, no tratado, afirmo que a lei moral seja a condição sob a qual primeiramente podemos tornar-nos conscientes da liberdade, quero apenas lembrar que a liberdade é sem dúvida a ratio essendi da lei moral, mas que a lei moral é a ratio cognoscendi da liberdade. Pois, se a lei moral não fosse pensada antes claramente em nossa razão, jamais nos consideraríamos autorizados a admitir algo como a liberdade (ainda que esta não se contradiga). Mas, se não existisse liberdade alguma, a lei moral não seria de modo algum encontrável em nós.

Desse modo, podemos concluir com Kant (2005, p.94) que "vontade livre e vontade submetida a leis morais são uma e a mesma coisa". Vale ressaltar, porém, a definição kantiana de liberdade prática: "A liberdade no sentido prático é a independência do arbítrio frente à coerção pelos impulsos da sensibilidade. Com efeito, um arbítrio é sensível na medida em que é afetado patologicamente (por motivação da sensibilidade)" (Kant, 1980, p.272, B 561-2, grifo do autor).

Uma ação, no âmbito da ética kantiana, só possui retidão moral se ela for realizada por dever, ou seja, se for realizada de acordo com a lei fundamental da razão prática pura. Somente assim tal ação poderá ser considerada livre, isto é, se a realização da mesma for causada por uma vontade incondicionada, diferentemente do que ocorreria se a vontade tivesse sido determinada por princípios empíricos. Ser livre, portanto, é agir por dever. Segundo Höffe (1986, p.167, tradução nossa): 
O dever é a ética em forma de mandamento, de exigência, de imperativo. Esta forma imperativa só tem sentido para aqueles sujeitos cuja vontade não é boa previamente e por necessidade. Carece de objeto no ser racional puro, cuja vontade, como em Deus, é sempre boa por natureza (cf. KpV, $\mathrm{V} 72,82)$. Só cabe falar de dever quando contra um apetite racional há impulsos concorrentes nas tendências naturais; quando contra um querer bom há também um querer mau ou malvado. Esta circunstância se dá em todo ser racional que depende também de motivacões sensíveis. Este ser racional, impuro, ou finito, é o homem. Quando Kant explica a ética apelando ao conceito de dever, procura conceber o homem como um ser moral. ${ }^{1}$

E para Rohden (1981, p.82, grifo do autor), o fundamento do dever é a liberdade:

Kant pergunta-se qual é a raiz, tanto do dever como daquele valor que os homens se dão unicamente quando praticam o seu dever. E responde que a raiz de ambos só pode ser a liberdade da pessoa, que, independente do mecanismo da natureza, subordina-se a leis morais e, como pertencente ao mundo inteligível, é ao mesmo tempo sujeito dessas leis autônomas.

1 "El deber es la ética en forma de mandato, de exigencia, de imperativo. Esta forma imperativa sólo tiene sentido para aquellos sujetos cuya voluntad no es buena previamente y por necesidad. Carece de objeto en el ser racional puro, cuya voluntad, como en Dios, es siempre buena por naturaleza (cf. KpV, V 72, 82). Sólo cabe hablar de deber cuando además de un apetito racional hay impulsos concurrentes en las tendencias naturales; cuando además de un querer bueno hay también en querer malo o malvado. Esta circunstancia se da en todo ser racional que depende también de motivaciones sensibles. Ese ser racional no puro, o finito, es el hombre. Cuando Kant explica la ética apelando al concepto de deber, intenta concebir al hombre como ser moral." 
Kant esclareceu, na Fundamentação, ser a vontade negativamente livre, quando ela "pode ser atuante independente de causas estranhas a determiná-la", e ser esta liberdade então ao mesmo tempo positiva, quando contivesse uma legislação própria, sendo, portanto neste sentido autônoma. A vontade é, pois, livre neste sentido, quando ela é livre da sensibilidade (das inclinações) e ao mesmo tempo é determinada por uma lei própria - da razão pura. O resultado é, pois: só se o homem for pensado como livre, poderia ele ser determinado pela razão pura. Como não existe no mundo da experiência uma liberdade deste tipo, deve-se então supor que o homem, na medida em que deve poder agir moralmente, é membro de um mundo inteligível.

Pois agora vemos que, quando nos pensamos livres, nos transpomos para o mundo inteligível como seus membros e reconhecemos a autonomia da vontade juntamente com a sua consequência - a moralidade; mas quando nos pensamos como obrigados, consideramo-nos como pertencentes ao mundo sensível e contudo ao mesmo tempo também ao mundo inteligível. (Kant, 2005, p.103).

Quando um sujeito age pela ideia de liberdade, ele está, de certo modo, agindo conforme as leis do mundo inteligível, por conseguinte, segundo a lei moral. É neste momento, pela ideia de liberdade, que nos arrebatamos de todo interesse empírico e demonstramos nosso interesse racional pela ação. Para Rohden (1981, p.66-7),

o interesse racional é uma satisfação da razão prática de um ente finito proveniente da possível concordância do seu objeto ou de sua ação com a sua condição subjetiva, que é a causalidade da sua vontade. Com outras palavras, nós temos um interesse pelo bem determinado pela razão, na medida em que o interesse pode ser reconduzido à sua condição originária ou 
ser expressão dela. Eu afirmo que tal condição provocadora do interesse é a liberdade.

Portanto, podemos concluir com Rohden (idem, p.80) que

somente quando o homem pratica a moralidade com base num exclusivo interesse por ela, a sua ação toma um valor prático. Visto que o interesse da razão pela moralidade requer a autoconsciência da razão prática, a possibilidade de um interesse da razão pela lei depende, concluímos, da redução da lei à liberdade, a qual então tem que possuir a primazia da lei.

A liberdade é pressuposto fundamental para que a razão possa se reconhecer como razão prática, isto é, capaz de determinar uma vontade com vistas a um fim cujo interesse nada mais é que a produção de ações fundadas em princípios racionais. 


\section{Considerações finAIS}

Todos os seres racionais possuem seus motivos para agirem de determinado modo ao invés de outro, pois se suas ações estivessem desprovidas de um fundamento, ocorreria o absurdo de encontrarmos na Natureza efeitos sem causas.

Isso significa dizer que as ações humanas acontecem em função da motivação da vontade, mesmo ocorrendo na maioria dos casos que os homens não tenham o pleno conhecimento sobre qual espécie de motivo, empírico ou racional, estejam fundadas suas escolhas.

O homem carece de um motivo para que o arbítrio determine a vontade, porque se não houvesse um motivo, a máxima da ação estaria fundada na indiferença, na qual tanto a lei quanto a inclinação teriam o mesmo peso na balança, e a decisão por uma ou por outra ocorreria sem uma razão suficiente.

A questão da motivação das ações humanas no texto da Fundamentação mostra um Kant determinado a fundamentar a moral na motivação provinda da razão, ou seja, em deixar claro que ações morais dependem de ser produzidas por motivos estritamente racionais, sem mesclas com o empírico. 
No entanto, o homem, além de uma parte racional, possui também uma parte sensível. Por isso, segundo o texto da Fundamentação temos de observá-lo sob um duplo ponto de vista, pois além de estar submetido às leis de um mundo sensível, o homem possui a razão que o torna membro de um mundo inteligivel.

Kant define o mundo sensível como o todo dos seres sensíveis enquanto considerados fenômenos, ao passo que o mundo inteligível, o todo dos seres racionais como coisas em si mesmas.

A ideia de um mundo inteligível é necessária para podermos pensar em um reino dos fins ou em um mundo moral:

De resto a idéia de um mundo inteligível puro, como um conjunto de todas as inteligências, ao qual pertencemos nós mesmos como seres racionais (posto que, por outro lado, sejamos ao mesmo tempo membros do mundo sensível), continua a ser uma ideia utilizável e lícita em vista da crença racional, ainda que todo o saber acabe na fronteira deste mundo, para por meio do magnífico ideal de um reino universal dos fins em si mesmos (dos seres racionais), ao qual podemos pertencer como membros logo que nos conduzamos cuidadosamente segundo máximas da liberdade como se elas fossem leis da natureza, produzir em nós um vivo interesse pela lei moral. (Kant, 2005, p.116)

Portanto, necessitamos da ideia de um mundo inteligível, pois do modo como o mundo sensível é constituído e regido pelas leis da necessidade, não há espaço para as realizações de ações fundadas na lei da liberdade.

Desse modo, na consciência de si, o homem kantiano se vê cindido entre razão e sensibilidade. O homem fica diante de uma encruzilhada quando sua vontade tem de decidir se se determina conforme as exigências da razão ou se se deixa conduzir pelas solicitações da sensibilidade. A ação es- 
colhida pelo sujeito agente pode ser julgada sob duas perspectivas distintas, isto é, ela pode ocorrer como sendo a melhor do ponto de vista moral, quando fundada na razão, ou a melhor ação produzida para saciar o desejo, quando fundada na sensibilidade.

Uma ação moral depende de que a lei constitua o fundamento determinante da vontade, e isso requer que a vontade se determine exclusivamente pela razão e produza uma ação totalmente desprovida de interesse empírico, como por exemplo, a satisfação dos desejos sensíveis.

Desse modo, o caminho para a moralidade implica renúncia dos prazeres sensíveis e de toda ação que possa ser motivada pela sensibilidade. A escolha pela lei na determinação da vontade requer a coerção pela razão dos impulsos sensíveis, e as ações efetuadas por essa vontade, para que possam ter valor moral, tem de ser realizadas exclusivamente por dever. O dever pode ser definido como a obrigação de todo ente racional de agir conforme a lei moral, isto é, conforme a representação pura e simples da lei.

O homem tem por obrigação seguir a lei, por conta de sua vontade não ser imediatamente determinada por este princípio, como ocorre com a vontade divina, pois, além da razão, o homem possui um corpo e inclinações. Portanto, a lei prática pura impõe a disciplina do dever ao homem e a todo ente finito detentor de uma dupla natureza.

Quando o homem realiza uma ação por dever, ele age a contragosto de suas inclinações. Com efeito, por mais que o homem tente realizar suas ações exclusivamente por dever e, desse modo, tente conformar sua máxima à lei, o homem, na condição de ente finito, sempre encontrará obstáculos subjetivos provindos de seus apetites e inclinações.

A ética kantiana também mostra que uma ação produzida pela motivação da felicidade não tem valor moral, pois a lei não diz o que devemos fazer para sermos felizes, mas o que devemos fazer para sermos dignos de felicidade. 
Embora a ética kantiana considere somente a ação efetuada por dever como a única instituída de conteúdo moral, esta exigência ainda não constitui propriamente um motivo para que a vontade seja determinada exclusivamente pela lei da razão.

É inegável que do modo como nossa natureza de entes sensíveis é constituída, as solicitações do desejo se impõem como se fossem as primeiras e originais, e se esforçam por determinar a vontade. Ora, como somos mais fortemente inclinados a realizar aquilo que não carece de muito esforço torna-se mais fácil colocar nossos desejos como fundamento de nossa vontade.

O homem que se deixa conduzir exclusivamente pelos impulsos sensíveis coloca a felicidade própria como fundamento de determinação da vontade. Kant (2003, p.257, grifo do autor) definirá este ato na segunda Crítica de presunção, que significa fazer de si mesmo regra prática universal de conduta.

Esta propensão ${ }^{1}$ a fazer de si mesmo, como base nos fundamentos determinantes subjetivos de seu arbítrio, o fundamento determinante objetivo da vontade em geral pode ser chamada de amor de si, o qual, se se converte em legislativo e em princípio prático incondicionado, pode ser chamado de presunção.

Todavia, a vontade cujo fundamento determinante é o dever rompe em absoluto com a presunção e até a limita ou a abate, na medida em que está fundada em uma lei pura que contém a objetividade necessária de um princípio de conduta que se pretenda universal.

1 Propensão é um conceito definido por Kant como "a predisposição para a ânsia de uma fruição" (1992, p.34). 
É impossível ao sujeito simplesmente renunciar ao imperativo. No entanto, como o próprio Kant (2005, p.40) afirma, é impossível termos conhecimento de uma ação motivada pelo puro dever no mundo sensível:

Na realidade, é absolutamente impossível encontrar na experiência com perfeita certeza um único caso em que a máxima de uma ação, de resto conforme ao dever, se tenha baseado puramente em motivos morais e na representação do dever.

Diante dessa constatação, fica a pergunta: é possível a realização do dever? A ética kantiana faz algum sentido ou não passa de uma quimera?

É possível a realização do dever se agirmos como se nossa vontade fosse determinada a priori pela razão e ponderar sempre sobre as condições sob as quais muitas vezes não acontece o que devia acontecer.

Quando se trata de julgar moralmente uma ação, não basta analisar apenas a aparência, mas sim ir ao fundo do ânimo e buscar os verdadeiros motivos, a real intenção por trás da realização daquela ação.

O ensinamento da primeira Crítica de que existe algo para além do dado, isto é, para além do fenômeno, deve ser aplicado também no campo prático, quando Kant nos adverte para o fato de que por detrás de nossas ações existe algo mais, que está relacionado à intenção do sujeito agente, ou seja, devemos sempre observar que por detrás daquilo que nossas ações parecem ser, pode estar uma intenção oposta.

Se desejarmos seguir os preceitos kantianos, temos de estar sempre atentos ao observarmos os verdadeiros motivos em que se assentam nossas ações, pois aquelas nas quais depositamos toda nossa crença na realização por causa do estrito do dever, quando muito podem se apresentar como fruto de uma inclinação imediata, ou ainda de uma inten- 
ção egoísta enraizada em nossos corações. O maior ato aparente de caridade pode muitas vezes esconder uma intenção extremamente egoísta.

Podemos concluir, por conseguinte, que o homem nunca será santo, visto que sua vontade não é pura, pois admite a concorrência da sensibilidade em sua determinação. Por estas razões Kant (2003, p.296-7, grifo do autor) em determinada passagem da segunda Crítica afirma:

O nível moral, em que o homem (de acordo com toda a nossa perspiciência, também cada criatura racional) se situa, é o do respeito pela lei moral. A disposição que o obriga a observá-la é a de cumpri-la por dever, não por espontânea inclinação e por esforço porventura não ordenado, assumido por si e de bom grado; e seu estado moral, em que ele pode cada vez encontrar-se é o de virtude, isto é, de disposição moral em luta e não o de santidade, na pretensa posse de uma completa pureza das disposições da vontade.

Desse modo, a ética kantiana não deixa o homem vaguear entre sonhadas perfeições morais, como uma pretensa aquisição de santidade da vontade, limitando o alcance das ações humanas simplesmente ao terreno da virtude.

Paton (1971, p.52, tradução nossa) afirma que o próprio Kant duvidava de que ele pudesse ter uma vontade determinada exclusivamente por motivos racionais: "O que ele duvida é da presença real de uma tal vontade santa em si próprio e em seus contemporâneos". ${ }^{2}$ Em outra passagem, Paton (idem, p.53, tradução nossa) diz que Kant estava preocupado em mostrar a debilidade do julgamento moral dos alemães: "Era certamente um aviso muito necessário de encontro a algumas das fraquezas do temperamento ale-

2 "What he doubts is the actual presence of such a holy will in himself and in his fellow men." 
mão, embora tais fraquezas não estejam restritas de nenhuma maneira aos alemães".3

A ética kantiana aponta para dois caminhos a serem seguidos: o da liberdade ou o da escravidão. $\mathrm{O}$ homem pode ser livre para seguir os princípios que sua razão é capaz de formular, e desse modo exercer sua autonomia da vontade, ou tornar-se escravo dos seus desejos e viver de modo heterônomo.

A autonomia em sentido estrito exige não apenas que a lei não seja dada pelo objeto, como também que a vontade não seja determinada por inclinações sensíveis. Se a vontade busca a lei fora dela mesma, ou é determinada por inclinações sensíveis, deixa de ser legisladora e passa a ser heterônoma. A vontade, se é autônoma, só pode ser determinada objetivamente pela lei moral e subjetivamente pelo respeito a esta lei. O móbil da vontade deve ser a própria lei; por isso, no plano ético, a ação é realizada não apenas conforme o dever, mas por dever; pois o móbil é incluído na lei, de forma que tem-se de cumprir a letra e também estar de acordo com o espírito, ou seja, com a intenção. (Terra, 2004, p.21)

Comumente somos atraídos pelo caminho mais fácil, e por isso ao invés de buscarmos a dignidade de sermos felizes, buscamos a felicidade imediata, isto é, a satisfação de nossos desejos sensíveis.

O estado ao qual o homem pode vir a encontrar-se quando motivado pelos princípios da razão será o de virtude, que significa uma forte disposição em lutar contra estas inclinações, mas nunca será santo, como alguns homens movidos pela presunção acreditam ser.

3 "It was certainly a very necessary warning against some of the weaknesses of the German temperament, though such weaknesses are by no means confined to Germans." 
O mundo dos sentidos pode também ser denominado como sendo o mundo do ser, ao passo que o mundo inteligível, o mundo do dever ser. O mundo do ser é regido por leis da necessidade, independentes da vontade do sujeito; já o mundo do dever ser tem como lei a liberdade.

Há um oceano dividindo o mundo onde as coisas são (mundo sensível) e o mundo no qual as coisas deveriam ser (mundo inteligível - moral). No entanto, um dos aspectos positivos da reflexão kantiana é mostrar que este oceano é navegável, e que outro mundo, mais digno, é possível. Para tanto, os motivos determinantes da vontade humana devem pautar-se por princípios universais ao invés de sentimentos particulares, por conseguinte, pelo ego. 


\section{REFERÊNCIAS BIBLIOGRÁFICAS}

ALliSON, H. E. Kant's theory of freedom. Cambridge: Cambridge University Press, 1995.

ALMEIDA, G. A. de. Liberdade e moralidade segundo Kant. Analytica, Rio de Janeiro, v.2, n.1, p.175-202, 1997.

AXINN, S. Ambivalence: Kant's view of human nature. Kant Studien, v.72, n.2, p.169-174, 1981.

BECK, L. W. Apodictic imperatives. Kant Studien, v.49, p.724, 1957.

HÖFFE, O. Immanuel Kant. Barcelona: Herder, 1986.

KANT, I. A religião nos limites da simples razão. Lisboa: Edições 70, 1992.

. Crítica da faculdade do juízo. Tradução Valério Rohden e Antonio Marques. 2.ed. Rio de Janeiro: Forense Universitária, 1995.

. Crítica da razão prática. Tradução Valério Rohden.

São Paulo: Martins Fontes, 2003. Ed. Bilingue.

. Crítica da razão pura. São Paulo: Abril Cultural, 1980 (Os pensadores).

. Fundamentação da metafísica dos costumes. Tradução Paulo Quintela. Lisboa: Edições 70, 2005. 
Idéia de uma história universal de um ponto de vista cosmopolita. Tradução Rodrigo Naves e Ricardo Terra. São Paulo: Brasiliense, 1986.

LEBRUN, G. A aporética da coisa em si. In: Sobre Kant. São Paulo: Iluminuras, 2001.

PATON, H. J. The categorical imperative: a study in Kant's moral philosophy. Philadelphia: University of Pennsylvania Press, 1971.

REATH, A. Kant's theory of moral sensibility. Respect for the moral law and the influence of inclination. Kant Studien, v.80, n.3, p.284-302, 1989.

ROHDEN, V. Interesse da razão e liberdade. São Paulo: Ática, 1981.

Introdução à edição brasileira. In: KANT, I. Crítica da razão prática. São Paulo: Martins Fontes, 2003. Ed. Bilingue. p.IX-LIX.

TERRA, R. Kant e o direito. Rio de Janeiro: J. Zahar, 2004. (Passo-a-passo).

TUGENDHAT, E. Lições sobre ética. 3.ed. Petrópolis: Vozes, 1996.

\section{Bibliografia suplementar}

ALMEIDA, G. A. de. Moralidade e racionalidade na teoria moral kantiana. In: ROHDEN, V. (Org.). Racionalidade $e$ ação: antecedentes e evolução atual da filosofia prática alemã. Porto Alegre: Editora da Universidade Federal do Rio Grande do Sul, p.94-103. (Diálogos Brasil-Alemanha, n.3).

ALMEIDA, G. A. de. Crítica, dedução e facto da razão. Analytica, Rio de Janeiro, v.4, n.1, p.57-84, 1999.

BECK, L. W. A Commentary on Kant's Critique of practical reason. Chicago: Chicago University Press, 1966.

DELBOS, V. La philosophie pratique de Kant. Paris: Presses Universitaires de France, 1969. 
HECK, J. A liberdade em Kant. Porto Alegre: Movimento, 1983.

MACBEATH, M. Kant on moral feeling. Kant Studien, v.64, n.3, p.283-314, 1973.

PASCAL, G. O pensamento de Kant. 7.ed. Petrópolis: Vozes, 2001.

PAVÃO, A. Heteronomia e imputabilidade na fundamentação da metafísica dos costumes. Kriterion, Belo Horizonte, n.105, p.119-135, jun.2002.

PIMENTA, P. P. G. Reflexão e moral em Kant. Rio de Janeiro: Azougue, 2004.

PYBUS, E. M., BROADIE, A. Kant's concept of respect. Kant Studien, v.66, n.1, p.58-64, 1975.

ROHDEN, V. Razão prática pura. Dissertatio, Pelotas, n.6, p.69-98, 1997.

Juízo e reflexão desde um ponto de vista prático. $O$ que nos faz pensar, Rio de Janeiro, v.9, p.40-53, 1995.

O problema metodológico de demonstração da razão prática. Revista IFCH, Porto Alegre, v.5, p.85-96, 1977.

O humano e racional na ética. Studia Kantiana, v.1, n.1, set. 1988.

TAVARES, M., FERRO, M. Análise da obra Fundamentação da metafísica dos costumes de Kant. 3.ed. Lisboa: Presença, 2000. 


\section{SOBRE O LIVRO}

Formato: $12 \times 21 \mathrm{~cm}$

Mancha: $20,4 \times 42,5$ paicas

Tipologia: Horley Old Style 10,5/14

$1^{\text {a }}$ edição: 2009

\section{EQUIPE DE REALIZAÇÃO}

\section{Coordenação Geral}

Marcos Keith 




\section{CULTURA}

ACADÊMICA 